$$
\text { UNIVERSIDADE DE SÃO PAULO }
$$

FACULDADE DE FILOSOFIA, LETRAS E CIÊNCIAS HUMANAS

DEPARTAMENTO DE LETRAS MODERNAS

PROGRAMA DE PÓS-GRADUAÇÃO NA ÁREA DE ESTUDOS LINGUÍSTICOS,

LITERÁRIOS E TRADUTOLÓGICOS EM FRANCÊS

\title{
RELAÇÕES CULTURAIS BRASIL-FRANÇA NAS CRÔNICAS DE BRITO BROCA
}

\section{Ronaldo Guimarães Galvão}

Dissertação apresentada ao Programa de Pós-Graduação na Área de Estudos Linguísticos, Literários e Tradutológicos em Francês do Departamento de Letras Modernas da Faculdade de Filosofia, Letras e Ciências Humanas da Universidade de São Paulo, para a obtenção do título de Mestre em Letras.

Orientadora: Prof. ${ }^{\mathrm{a}}$ Dr ${ }^{\mathrm{a}}$. Regina Maria Salgado Campos 


\section{AGRADECIMENTOS}

À Profa. Dra. Regina Salgado Campos, pela extrema paciência, compreensão e disposição em me orientar. Obrigado mesmo!

À Profa. Dra. Maria Lídia, por ter me despertado o gosto pela pesquisa e por ter me apresentado ao trabalho de Brito Broca.

Aos funcionários da Biblioteca do IEB, pela atenção.

À Secretaria de Educação, pela concessão da bolsa.

Aos amigos de Guará/Lorena, Assis e São Paulo, pela paciência e torcida.

Ao amigo Daniel, primeiro grande incentivador das minhas atividades acadêmicas.

Aos meus pais, pelo apoio que sempre me deram.

À Rejane, sem a qual as minhas horas de trabalho seriam mais difíceis, agradeço imensamente pela compreensão, pelo carinho, pelas palavras de incentivo e pela cumplicidade de sempre. 


\section{RESUMO}

Esta pesquisa consiste no estudo das relações culturais entre o Brasil e a França a partir da análise das crônicas literárias de José Brito Broca, publicadas exclusivamente em jornais e revistas do Brasil. O tema é abordado considerando a presença de escritores e intelectuais brasileiros na França e de escritores e intelectuais franceses no Brasil. Além de demonstrar a preocupação recorrente do crítico com as marcas francesas em nosso meio literário, este estudo fortalece a discussão das relações entre os dois países em diferentes momentos da história.

Palavras-chave: Brito Broca, relações Brasil-França, crônica, vida literária, jornalismo literário. 


\begin{abstract}
This research consists in surveying the cultural relationship between Brazil and France based on the analysis of José Brito Broca's literary chronicles which have been published exclusively in Brazilian newspapers and magazines. The research is carried out taking into account the presence of Brazilian writers and intelectuals living in France as well as French writers and intelectuals located in Brazil. It demonstrates the critic's recurrent concern for the French signs in our literary enviroment. Furthermore, it strengthens the discussion of the relationship between the two countries in different moments of History.
\end{abstract}

Key-words: Brito Broca, relationship Brazil France, chronicles, literary life, literary journalism. 


\section{SUMÁRIO}

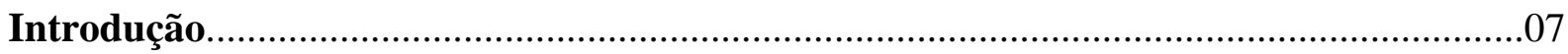

\section{Parte I}

Pressupostos para uma leitura interpretativa de Brito Broca

\section{Capítulo I}

\section{A crônica como suporte}

A contribuição de Brito Broca para o gênero.................................................................10

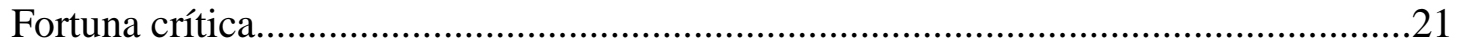

\section{Parte II}

\section{Relações culturais}

\section{Capítulo II}

\section{Brasileiros na França}

Domingos Borges de Barros e Delille (1805).............................................................

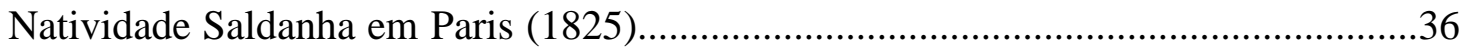

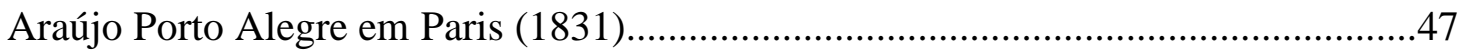

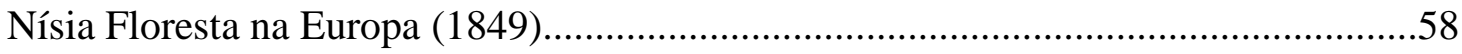

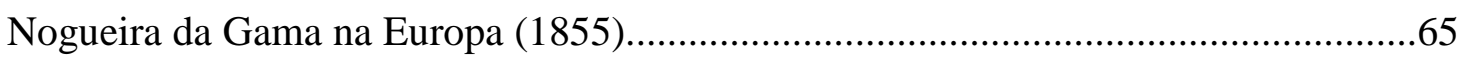

Artur de Oliveira e Victor Hugo (1870)................................................................ 71

França Júnior na Exposição Internacional de Paris (1878)...........................................79

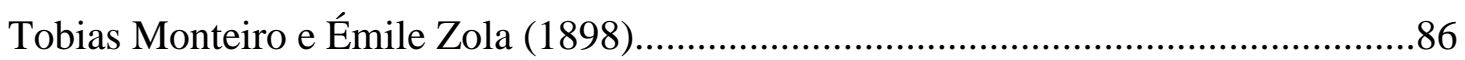

\section{Capítulo III}

\section{Franceses no Brasil}

Jacques Arago e João Caetano $(1817,1850,1854)$..................................................95

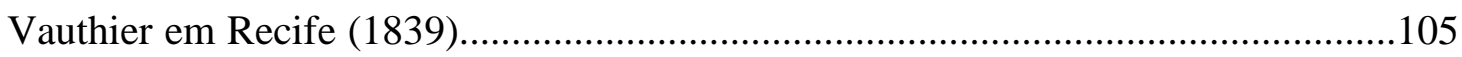

François Biard (1858) e o casal Agassiz (1865)......................................................112 


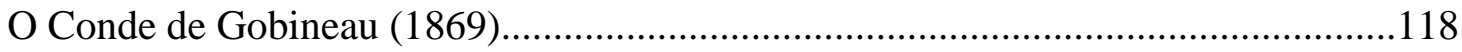

Anatole France e Georges Clemenceau (1909 - 1910).............................................127

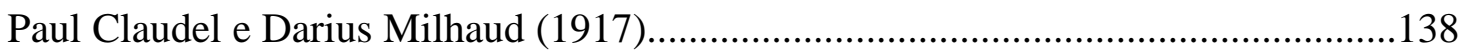

Abel Bonnard e Tristão de Athayde (1927)..........................................................143

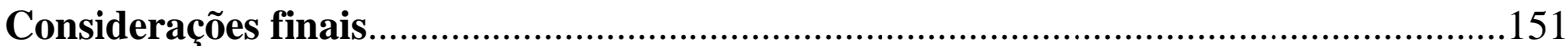

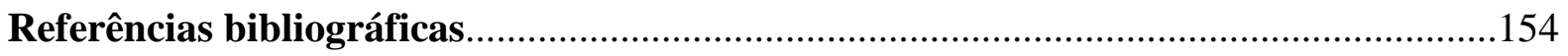




\section{INTRODUÇÃO}

O presente trabalho pretende contribuir para os estudos das relações Brasil-França, verificando o processo de intercâmbio de culturas entre os dois países nas crônicas literárias do jornalista brasileiro José Brito Broca (1903 - 1961). Enfeixadas em dez volumes postumamente publicados, esses artigos correspondem a um material até então pouco utilizado no tratamento das referências francesas do cronista. Na maioria dos casos, tem-se recorrido a Letras francesas, obra na qual se reúnem os artigos que Broca escreveu de 1956 a 1960, no suplemento literário de O Estado de São Paulo. As crônicas desse suplemento tinham como objetivo promover a divulgação da atualidade literária vivida na França daquela época. Reunidas em livro, servem como material para a análise do modo de apreensão do universo literário francês que chegava ao Brasil.

Já as crônicas recolhidas a partir do projeto de Alexandre Eulalio, foram agrupadas atendendo a outros critérios. Dessa forma, os artigos em que se encontravam as referências francesas de Brito Broca acabaram se ligando a outros que na maioria das vezes não correspondiam à mesma temática. $\mathrm{O}$ primeiro trabalho dessa pesquisa consistiu, portanto, no levantamento das referências francesas nessas crônicas. Feito isso, constatou-se que havia um grande número de artigos relatando a estada de brasileiros na França e também a estada de franceses no Brasil. O tema era recorrente e chamava a atenção do próprio Brito Broca que nos artigos sempre se questionava a respeito do motivo que levou alguns brasileiros a não relatarem suas temporadas na França.

Estabelecido o tema, julgou-se necessário um estudo enfocando a atividade de Brito Broca como cronista, tanto no que diz respeito à sua contribuição ao gênero, uma vez que sua produção toda se vincula à publicação feita em jornais e revistas especializadas, quanto no que diz respeito ao julgamento que outros especialistas fizeram sobre seu trabalho, o qual se pautava em um método próprio nas análises dos fatos literários, sempre tomando como base seu autodidatismo. 
Com base nisso, a apresentação deste trabalho se dá em três capítulos. O primeiro deles, "A crônica como suporte", pretende apresentar um estudo sobre o gênero, destacando seu surgimento e sua evolução no Brasil. Procura-se ainda identificar o modo como Brito Broca se serviu da crônica e também a contribuição que ele lhe deu. Além disso, é feito um estudo procurando enfocar a sua fortuna crítica, quase toda composta por especialistas de formação acadêmica, cujas bases teóricas conduzem a uma reflexão de maior rigor metodológico, conforme o que se discute dentro das universidades. Dessa forma, nossa intenção é verificar qual a posição desses profissionais diante de um projeto crítico feito ao longo de trinta anos na imprensa brasileira.

O segundo capítulo intitula-se "Brasileiros na França" e traz a análise das crônicas de Brito Broca que relatam as histórias de escritores e intelectuais brasileiros que estiveram na França e se relacionaram com algum outro escritor ou intelectual francês.

No terceiro capítulo, intitulado "Franceses no Brasil", segue-se o mesmo procedimento do anterior, porém investigando a estada de escritores e intelectuais franceses no Brasil e as relações construídas no país com os brasileiros.

Vale lembrar que nesses dois capítulos procuramos sempre nos ater às referências bibliográficas indicadas pelo cronista com o objetivo de divulgar tais fontes. Entretanto, este foi um dos principais desafios da pesquisa uma vez que é muito comum a não citação da fonte consultada pelo cronista. Para que algumas "lacunas" fossem preenchidas foi necessário, no entanto, recorrer a outras obras que nem sempre correspondiam àquelas utilizadas por Broca. Dessa forma, este trabalho, tendo também a intenção de investigar as fontes que Broca utilizou para compor seus textos, quer também oferecer uma contribuição bibliográfica às pesquisas cujos temas sejam semelhantes a este. A intenção não é desmembrar o tecido e apontar os defeitos ou deslizes da obra do cronista, é antes o desejo de poder compartilhar desse conhecimento, trazendo suas referências mais ao alcance daqueles que delas possam necessitar. 
PARTE I

PRESSUPOSTOS PARA UMA LEITURA INTERPRETATIVA DE BRITO BROCA 


\title{
CAPÍTULO I
}

\section{A CRÔNICA COMO SUPORTE}

\author{
Nada será fútil ou desprezível na crônica, sempre que \\ ela registre com precisão de detalhes, mesmo os mais \\ insignificantes, os hábitos, os costumes do teor de vida \\ da cidade. (Brito Broca)
}

\section{A contribuição de Brito Broca para o gênero}

Chegara a São Paulo havia uma semana e já se dirigindo ao prédio do jornal A Gazeta, pediu para falar com o diretor. Cásper Líbero o recebeu, indagando ao jovem o que desejaria fazer ali no jornal. "Crônica" - foi a resposta. "Mas que espécie de crônica - exigiu o diretor - crônica política não será comercial, o senhor não terá conhecimentos especializados para isso..." Foi quando o rapaz o interrompeu: "Literária”. O ano era 1927. Com o pseudônimo de Lauro Rosas, escrevendo crônicas na abertura da seção social dessa folha, Brito Broca dava início à sua carreira jornalística.

Mais de trinta anos de atuação como cronista literário certamente garantem a Brito Broca determinada posição dentro da história desse gênero no Brasil. Gênero escorregadio, cuja definição abarca uma série de elementos a serviço da História e da Literatura, e da própria História da Literatura. Manuseado por muitos, desde o surgimento da imprensa no Brasil, ou, se quisermos ir além, desde a carta de Caminha relatando o nosso descobrimento, o gênero naturalmente haveria de passar por um longo período de mutação, até se definir como o que hoje ficou sendo conhecido como o relato do circunstancial acrescido das impressões de seu criador. Sua verve literária é seu caracterizador mais marcante na atualidade. 
Aparentemente, qualquer coisa que se diga sobre a crônica parece sempre remeter à ideia de um déjà $v u$, de terreno já pisado, medido e delimitado, em razão de muito já se ter discutido a seu respeito. Do seu significado mais conhecido, o da palavra crônica e sua etimologia grega (khronos - tempo), definindo-a como o relato dos acontecimentos em ordem cronológica, muito já se conhece; e os dicionários, na sua maioria, assim o registram. Da sua origem francesa, ligada ao rez-de-chaussée dos jornais, situada no rodapé da primeira página de muitos deles, verifica-se seu caráter de entretenimento - um espaço livre onde os mais variados assuntos eram tratados; local também tido como espaço de experimentação para os escritores que procuravam desenvolver suas narrativas. Daí até o aparecimento do romanfeuilleton o caminho é relativamente curto; e a nova técnica utilizada pelos escritores - o corte da narrativa no momento culminante de uma cena - garantia a compra da folha do dia seguinte, contribuindo para o aumento da venda dos jornais e de sua vulgarização. Em 1836, "Émile de Girardin e seu ex-sócio e pirateador, Dutacq, logo percebem as vantagens financeiras que dele tirariam. Dão ao feuilleton o lugar de honra do jornal, como é explicado no prospecto de lançamento de Le Siècle, a $1^{\circ}$ de julho de 1836 (...)” (MEYER, 1992, p.97).

No Brasil, quem inaugura o gênero é Francisco Otaviano de Almeida Rosa em folhetim no Jornal do Commercio do Rio de Janeiro, em 1852. Vivia-se o início do Romantismo. José de Alencar e Manuel Antônio de Almeida também constam na lista dos pioneiros da crônica brasileira. O primeiro, substituindo Francisco Otaviano no Correio Mercantil, "imprimiu à crônica a mais alta categoria intelectual”. O segundo, alternando com Alencar, escrevia suas crônicas sob o título "Páginas menores", fazendo notar que o “complexo de inferioridade" em relação ao gênero já vem de longa data. Lembra Afrânio Coutinho que muitos escritores "nutriam a natural desconfiança de que suas crônicas não subsistiriam muito tempo", sem considerarem, contudo, que foi a própria crônica que abriu caminhos a muitos deles.

Entretanto, afirma Coutinho, o "folhetim ainda estava muito longe do tempo em que seria subdividido em várias outras seções, segundo cada assunto, de modo que nele se acumulava uma porção de coisas diferentes, às vezes mesmo inteiramente díspares" (COUTINHO, 1997, p.125). As colunas jornalísticas de comentários tinham o aspecto de um "bazar asiático", em que "a imaginação poética dava imprevistas transfigurações às coisas 
mais vulgares ou prosaicas, por ser isso precisamente o que se exigia de um cronista naqueles ociosos tempos" (Ibidem).

Machado de Assis, é sabido, também se serviu muito do gênero. Como folhetinista, "revela a mesma finura de observação, a ironia piedosa e cética que marcam a sua visão do mundo", como expressou em seus romances e contos. O escritor, afirma Coutinho, "que também enxergara a crônica em alguns dos seus romances, consagrou-se ao gênero durante longos anos, contribuindo consideravelmente para a sua evolução na literatura brasileira" (Ibidem, p.126).

Dentro ainda do século XIX, escritores como Joaquim Manuel de Macedo, Quintino Bocaiuva, França Júnior e Araripe Júnior também produziram crônicas. Entretanto, na passagem do XIX para o XX verificam-se algumas transformações do gênero, que então sofria com os "ataques por parte da crítica naturalista, infensa à estética expressa nos folhetins, em que se misturavam a fantasia e a realidade”. Com Melo Filho, França Júnior e Raul Pompeia o gênero revestiu-se de um teor artístico, "em que o Parnasianismo predominava sensivelmente." Já com Olavo Bilac, "a crônica mostrava uma fisionomia diversa", visto que passou a "concentrar os seus comentários em determinado fato, acontecimento ou ideia, o que concorreu para dar a algumas de suas crônicas a feição de ensaios" (COUTINHO, 1997, p.127). Mas é a João do Rio, pseudônimo de Paulo Barreto, "a quem cabe inegavelmente o qualificativo de iniciador da crônica social moderna, no Brasil" (Ibidem, p.128).

É interessante notar que, escrevendo crônicas, Broca acabou escrevendo também sobre cronistas que de certa forma lhe agradavam, como é o caso de João do Rio. Em "As Marionetes de uma civilização", crônica recolhida em Horas de leitura, Brito Broca observava que João do Rio fazia "a crônica no verdadeiro sentido da palavra, que é história". Dessa forma, afirma que "pode-se dizer que João do Rio foi o nosso último cronista e o legítimo continuador de França Júnior, através de Machado de Assis, de quem sofreu a influência." Último cronista porque seus textos oferecem subsídios para o conhecimento de uma época, sobretudo a nossa belle époque; mas herdeiro da tradição de França Júnior, que em seus folhetins procurava sempre "amarrar" os temas discutidos numa crônica anterior

\footnotetext{
${ }^{1}$ Cf. SIMÕES, 2003/2004, p.235-246.
} 
àquela que discutia no momento. Nesse sentido, em outra crônica sobre João do Rio ${ }^{2}$, Brito Broca afirma:

De 1904 em diante, a remodelação do Rio reclamava o aparecimento de um novo "espectador" da cidade. Esse "espectador" foi João do Rio. O cabriolé e o tílburi característicos da paisagem machadiana cediam lugar ao automóvel. E justamente com uma página, "A Era do Automóvel", João do Rio abre seu livro Vida Vertiginosa: "O monstro transformador irrompeu bufando por entre os escombros da cidade velha, e como nas mágicas e na natureza aspérrima educadora, tudo transformou com aparências novas e novas aspirações”. (BROCA, 1991, p.243-4)

Brito Broca afirma ainda que depois de João do Rio "a crônica não teria decaído, e sim evoluído num sentido diverso de sua índole primitiva, perdendo o caráter histórico de registro de uma época." (BROCA, 1992, p.127) Com a voga do Simbolismo, muitos escritores desvirtuaram o objetivo da crônica, ligando-a àquelas "divagações abstratas, cheias de vocábulos raros, sem nada de concreto" (Ibidem). Os que se opuseram a essa tendência, como Gilberto Amado, Antônio Tôrres e Lima Barreto,

(...) imprimiram ao gênero novos rumos: o primeiro, colocando-a em termos de ensaio e interpretação sociológica; o segundo e o terceiro, em termos de polêmica todos se empenhando mais em criticar ou fustigar e satirizar, do que em descrever e retratar, à maneira de França Júnior e João do Rio, embora nestes não se excluísse, absolutamente, a sátira. (BROCA, 1992, p.127)

O gênero continuaria seu processo de mutação dentro de revistas ilustradas como a Fon-Fon, "onde Álvaro Moreira principiou a desfiar a encantadora melodia de suas crônicas." (COUTINHO, 1997, p.130) Entretanto, é a Antônio de Alcântara Machado que recai o título de renovador do gênero, semelhante a João do Rio. Segundo Afrânio Coutinho, suas crônicas entre 1926 e 1935, "desferiram enfim terrível golpe contra certo tipo de literatura modorrenta e afetada que teimava em sobreviver" (Ibidem). Com a coletânea de contos Brás, Bexiga e Barra Funda, de 1927, em que retrata o cotidiano dos imigrantes italianos em São Paulo por meio de uma narrativa com linguagem mais livre, próxima da coloquial, o escritor imprime novo um direcionamento à sua escrita. "Seus contos - assim os quis batizar o autor - são antes de tudo crônicas impressionistas, vivazes, nas quais se dissolvem os gizamentos da fabulação" (Ibidem, p.131).

\footnotetext{
2 "João do Rio e a Crônica Política", recolhida em Naturalistas, parnasianos e decadistas. Campinas, SP: Editora da UNICAMP, 1991, p. 242-8.
} 
A atmosfera de renovação observada na década de 1930 contribuiu para o desenvolvimento da crônica "sob novos múltiplos aspectos". Embora seja arriscado se falar em escola ou geração de cronistas, o período é marcado por uma presença muito forte de escritores que manejavam o gênero, imprimindo-lhe traços que o distanciariam cada vez mais de sua primeira acepção, ou seja, a de relato concatenado de fatos históricos. Dentre vários escritores que deixaram sua marca no gênero, o destaque é para Rubem Braga, "o escritor que entra para a história literária exclusivamente como cronista" (Ibidem, p.132). Segundo Afrânio Coutinho,

Sua técnica é dar pouco apreço aos fatos do mundo real e muita vez os escolhe como simples pretexto para a divagação pessoal. É seguramente o mais subjetivo dos cronistas brasileiros. E o mais lírico. Muitas de suas crônicas são poemas em prosa. Apresentando a originalidade de uma imaginação poética e erradia, Rubem Braga, em seu lirismo, escreve sem ornatos e alcança às vezes a simplicidade clássica, numa língua despojada, melodiosa, direta. (COUTINHO, 1997, p.132-3)

Nesse sentido, a crônica de Brito Broca parece fazer um caminho oposto. Ou pelo menos diferente dos rumos que o gênero parecia tomar na ocasião. Consciente de sua história, sobretudo da origem francesa do gênero, a qual aprova e toma para si, Broca procura se ater ao exercício da crônica com base nas histórias da vida literária, tanto as nacionais quanto as estrangeiras.

Em artigo de 13 de setembro de 1958, intitulado "Crônica na atualidade literária francesa", crônica afastava-se do verdadeiro sentido da palavra. Vai, portanto, buscar uma definição:

No Larousse du XXme. Siècle lemos as definições que aqui traduzimos: Crônica: história na qual os fatos são simplesmente registrados na ordem cronológica. Por extensão: "narrativa de um acontecimento de ordem particular", "Parte de um jornal ou de uma revista consagrado a uma ordem particular de notícias ou de fatos". Originariamente, a crônica identificava-se com história. Isso não só na França, como em Portugal e em outros países. Era a história feita pela simples narrativa dos acontecimentos por aqueles que os tinham presenciado, sem nenhuma preocupação de análise ou de exegese. (...) Mais tarde, quando os fatos começavam a ser reconstituídos através dos documentos, e interpretados frequentemente à luz de um pensamento filosófico, político ou religioso, a história tomou uma configuração própria, separando-se da crônica. Com o advento da imprensa, a crônica iria encontrar a sua expressão moderna no jornal. (BROCA, 1969, p.115)

\footnotetext{
${ }^{3} \mathrm{O}$ artigo foi recolhido em Letras Francesas, de 1969.
} 
Broca completa ainda a definição, afirmando que "não seria o simples relato de acontecimentos e sim o comentário sobre os mesmos, comentário leve, ressaltando determinados aspectos, estabelecendo paralelos, esclarecendo, e tirando conclusões" (Ibidem). Assim o cultivaram na França desde o século XIX, quando o jornalismo teve sua grande ascensão, possivelmente assim ainda era até aqueles dias, quando concluiu que o "destino da crônica na França é geralmente morrer nos jornais e nas revistas.” Em seguida, traça um paralelo em que verifica a situação do gênero entre nós:

\begin{abstract}
No Brasil, apesar da influência francesa, sempre se verificou tendência contrária, e agora mais do que outrora, porque estamos criando uma nova forma de crônica (ou dando erradamente esse rótulo a um gênero novo) que nunca medrou na França. Crônica é para nós, hoje, na maioria dos casos, prosa poemática, humor lírico, fantasia, etc., afastando-se do sentido de história, de documentário que lhe emprestam os franceses. Seria preciso descobrir um termo mais adequado para classificar essas páginas que na categoria de crônica encontramos com frequência em nossos jornais e revistas e nos quais prevalece o valor formal, o apuro estilístico, levando-nos a pressentir uma espécie de neoparnasianismo em prosa. Com esse tratamento literário e poético, a "crônica" decerto adquire outras condições de durabilidade no livro, mas isso precisamente por fugir à essência do gênero, à acepção em que os franceses costumam cultivá-la. (BROCA, 1969, p.117)
\end{abstract}

Comenta ainda Broca que a crônica não chegou a atingir "um alto nível” na França e nem passou a ser praticada por "grandes espíritos" em razão de sua proximidade com o ensaio. Lembrando André Gide, Brito Broca nos informa que a "França é um país de ensaístas", o que, segundo ele, implica dizer que "muita vocação de cronista" acabou inclinando-se para o "ensaísmo.” Um caso típico, lembra ainda, seria o de Valéry Larbaud que em sua obra Jaune, Bleu, Blanc apresenta muitas páginas que poderiam ser classificadas como crônica, não fosse "a sutileza das ideias" colocá-las "antes na categoria de ensaio". Uma linha tênue, portanto, parece diferenciar para os franceses a crônica do ensaio. Para Brito Broca, o "hábito do diário íntimo" praticado na França "absorve muito do material, ou melhor, do potencial de ideias, comentários e reflexões, que podia ser carreados para a crônica.” Dessa forma, ao escrever o diário íntimo com o propósito de publicá-lo é possível identificar no escritor francês "o espírito do verdadeiro cronista."

Embora contemporâneo de Ribeiro Couto, Mário de Andrade, Peregrino Júnior, Guilherme de Almeida, Manuel Bandeira, Marques Rebelo, Carlos Drummond de Andrade, Aníbal Machado, Sérgio Milliet, José Lins do Rego, Rachel de Queiroz e tantos outros escritores que também manejaram o gênero, Brito Broca, portanto, não teria se enveredado pelos novos caminhos da crônica porque já trazia consigo o intuito de fazer crônicas literárias. 
Nesse sentido, vale lembrar novamente Afrânio Coutinho quando afirma que a crônica é por natureza um gênero "eminente individual."

Dessa forma, pode-se dizer que a matéria prima das crônicas de Brito Broca diferencia-se da dos demais porque nem sempre está ligada aos fatos do dia a dia das cidades e de seus habitantes; relaciona-se na maioria das vezes a fatos da vida literária em que as "personagens" nem sempre mantêm uma relação direta com o cronista ou mesmo com a própria realidade. Isso, entretanto, não quer dizer que o cronista não tenha deixado de praticar o gênero encarando-o também dentro de uma perspectiva mais próxima de si, da vida real.

Em algumas crônicas, por exemplo, Broca mostra-se diante de impasses que o gênero impõe a qualquer um que venha a praticá-lo: a falta de assunto. Em "Uma Grande Responsabilidade", recolhida em Papéis de Alceste, o cronista escreve exatamente sobre o problema. Vejamos:

Há anos, quando eu ocupava uma seção diária como esta, acontecia-me, nas ocasiões em que me faltava assunto, recorrer à transcrição de um trecho qualquer de jornal ou revista que proporcionasse um pouco de pitoresco aos leitores.

Assim, numa manhã de calor como a de hoje em que me faltava disposição para forjar uma crônica, caiu-me sob os olhos um jornalzinho do Brás onde alguns plumitivos de bairro faziam as suas experiências literárias.

É bem fácil calcular a riqueza e a variedade de pitoresco que aí se encontravam. Um trechinho me atraiu particularmente a atenção pelo imprevisto das asneiras. Era a narrativa de um caso sentimental; mas que maravilha de paralelos, que inventiva assombrosa nas imagens!

Cortei aquilo e, com um nariz de cera evidentemente irônico, ofereci o pratinho aos leitores, declinando o nome do autor e do jornal para autenticar a transcrição. (BROCA, 1991, p.100)

A "falta de assunto" é um tema recorrente para os que escrevem crônicas. O caráter metalinguístico que o tema traz, permite ao leitor enxergar mais de perto o trabalho realizado pelo cronista, e sua luta diária sobre o que escrever. Brito Broca mostra os andaimes da construção de seu texto, estabelecendo um diálogo com o leitor, o que acaba de certa forma inserindo mais credulidade ao fato. Ainda em Papés de Alceste, podemos observar outro exemplo parecido com este. A crônica intitula-se "O homem e o assunto":

O cronista abriu o jornal pela manhã. Estava em busca de assunto. Mas o que ele queria não era o último discurso de Mr. Chamberlain, nem a notícia de um delito contra a economia popular. Isso seria para outros comentadores.

Procurava a nota extravagante de um desses acontecimentos invulgares, passados em terras longínquas, que, sem alterar a ordem do mundo, fornecem ótimos elementos para quinze minutos de maliciosa filosofia. 
E, às vezes, lá nas distâncias perdidas de Goiás, um homem que matou diferente dos outros, ou nas margens do Danúbio uma mocinha morrendo por causa de uma canção.

Eis aí o que convém ao cronista: o pitoresco, o raro, o romanesco. Apreciando o caso nas suas diferentes faces, não lhe será difícil tirar conclusões inéditas sobre a realidade da vida e as tristes contingências do gênero humano. (BROCA, 1991, p.48-9)

À procura de um assunto para o artigo do dia, muitas vezes o cronista se prende àquilo que Broca chama de "extravagante" e "pitoresco", pouco importando se "nesses comentários se jogue com os sentimentos, as paixões, o destino de uma criatura de carne e osso como nós!" Como a "criatura" está muito longe, o cronista não a vê mais do que como uma "cobaia", reduzida à "simples categoria de assunto, de um tema." Admite que seu trabalho serve-se das "extravagâncias desses indivíduos longínquos, como campo de experiência para toda sorte de reflexões paradoxais e ousadas." O cronista Brito Broca ainda conclui que é preciso este "tope com a história pitoresca (...) para que o pensamento se ponha a cabriolar à vontade, no jogo das deduções sagazes ou dos paralelos sutis." No entanto, sobra-lhe espaço para se questionar a respeito do "valor humano das criaturas" diante da "provável indiferença do cronista e do leitor, cujo destino faculta ao primeiro as mais felizes trouvailles" (Ibidem).

Papéis de Alceste é provavelmente a obra em que encontramos a maior variedade de assuntos tratados por Brito Broca. Vão desde exemplos como o que acabamos de ver até as suas crônicas da vida literária, passando, como o próprio cronista confessa, por aquelas que lhe servem como uma espécie de "diário íntimo". Vejamos:

\begin{abstract}
(...) quem faz literatura diariamente, ou mesmo, com frequência, nas colunas de imprensa, já realiza dessa forma uma transposição do diário íntimo ou da carta ao amigo. A experiência do que observamos de manhã ou à tarde, é logo aproveitada no que escrevemos à noite; e assim, depois dessa espécie de desabafo, já não sentimos a solicitação de registrar de outra maneira o fato. Quem possui, todos os dias, o público por confidente, experimenta naturalmente muito menos do que os outros a necessidade de fazer confidências aos amigos distantes. (BROCA, 1991, p.118)
\end{abstract}

Brito Broca, portanto, fez crônica no melhor sentido da palavra - ou pelo menos no sentido em que ele acreditava. Registrou vários momentos de transformação da cidade, como na crônica "Sobrevivência de uma época", em que relata "a notícia melancólica" da demolição da Vila Kyrial, "onde Freitas Vale manteve, durante três décadas, o seu famoso salão literário e artístico.” O cronista já se achava no Rio de Janeiro (mudara-se para lá em

\footnotetext{
${ }^{4}$ Crônica publicada em 26 de março de 1961, no Correio da Manhã. Atualmente integra o volume Teatro das letras. Campinas, SP: Editora da UNICAMP, 1993, p.18-21.
} 
1937), mesmo assim, num tom meio saudosista, a notícia leva-o a tecer alguns comentários sobre o processo de reurbanização da capital paulista. Dizia ele:

Pois agora, segundo me informam, aquele "palacete de linhas harmoniosas", da Rua Domingos de Morais, em Vila Mariana, acaba de ser atingido pelas máquinas tremendas do progresso. Há mais de vinte anos que, em visitas pouco frequentes a São Paulo, não tenho passado por ali. Imagino, no entanto, que a sobrevivência de Vila Kyrial já teria qualquer coisa de heroico, pressionada pelo sistema tentacular dos prédios de apartamentos - esses cortiços de luxo, como os denominou Álvaro Moreyra. Estaria com o seu destino traçado por essa fatalidade urbana das grandes metrópoles, de que Lewis Mulford nos dá um quadro tão perfeito no livro A Cultura das Cidades. (BROCA, 1993, p.19)

O cronista ainda relembra um pouco da figura do "Prince Royale du Symbole - Freitas Vale, o Magnífico" e suas reuniões. Observe-se, no entanto, que mesmo entristecido pela extinção do palacete da capital paulista, não deixa de inserir o nome de uma obra cujo incidente o faz lembrar. Isto não é uma constante no cronista que em muitos de seus artigos costuma omitir suas fontes, fato que Antonio Candido considera como "tributo à elegância ensaística". (CANDIDO, 1981, p.8)

Outra crônica que também demonstra certa relação do cronista com a cidade é "Roteiro Literário do Rio de Janeiro" ${ }^{5}$. Como o próprio nome sugere, Brito Broca, partindo da Rua do Ouvidor, traça um itinerário em que relaciona todos os nomes de ruas, bairros, comércios, etc. com alguma obra ou ocorrência da vida literária carioca. Seu ritmo é assim:

Em Botafogo localizou Aluísio Azedo $O$ Cortiço, que é por assim dizer o personagem principal do romance do mesmo nome. E Bernardo Guimarães cantou esse bairro, outrora o mais aristocrático do Rio, numa de suas poesias, de certo muito pouco conhecida. Na Travessa Martins Ferreira, ergue-se o velho casarão, onde morou Capistrano de Abreu. Na Rua Ipiranga ficava o Colégio Abílio satirizado por Pompeia $O$ Ateneu. O setor é ainda marcado pela residência de Álvaro Lins, Aurélio Buarque de Holanda, Marques Rebelo, todos no mesmo prédio - um dos prédios mais literários do Rio -; Otávio de Faria, Maurício Rosemblatt.

Em São Clemente fica um ponto culminante, não da história literária, mas da cultura brasileira: a casa de Rui Barbosa. Mais para sul, temos um verdadeiro arquipélago: as residências de Augusto Frederico Schmidt, Carlos Drummond de Andrade, Otto Maria Carpeaux e Jorge Lacerda. (BROCA, 1994, p.40)

O leitor é levado pelo cronista a excursionar pela cidade que muito ofereceu à vida literária brasileira. Ao final do artigo, Brito Broca insere uma nota na qual diz que seu “esboço de um roteiro literário do Rio não tem, naturalmente grandes ambições." São somente pontos de referência, lembra ele, sendo as omissões inúmeras.

\footnotetext{
${ }^{5}$ Publicada em outubro de 1949, no Jornal de Letras. Encontra-se no volume O repórter impenitente. Campinas, SP: Editora da UNICAMP, 1994, p.35-42.
} 
Entretanto, a sua principal contribuição para a crônica brasileira consiste no imenso levantamento que fez de vários episódios da vida literária do país. Nesse sentido, vale lembrar que a sua dedicação também se estende à literatura estrangeira, sobretudo a francesa com a qual muito se identificava, seja em relação aos escritores, seja em relação aos pensadores e suas ideias.

A vida literária no Brasil, por exemplo, há muito já se impôs como obra de referência dentro dos estudos literários do país em razão da abordagem que faz das relações entre literatura e sociedade. Nela, Brito Broca criou um quadro em que se observa a vida existente em torno da literatura: as relações entre os escritores, os locais que frequentavam, os jornais em que publicavam, as transformações ocorridas no Rio de Janeiro (como o "bota-abaixo" do prefeito Pereira Passos), as agremiações, as influências, as polêmicas etc. Optando por escrever "crônicas literárias", Brito Broca acabou agrupando uma série de relatos que traziam informações essenciais à compreensão de alguns fatos de nossa literatura, que mais tarde lhe serviriam de base para a composição dessa obra.

A vida literária francesa também foi tema de várias crônicas de Brito Broca. Entretanto, é algo que ainda necessita de pesquisa uma vez que as referências ao tema se encontram espalhadas nas obras do cronista, postumamente reunidas. E embora Letras francesas continue a ser a primeira referência ao assunto, é preciso notar que a obra traz a reunião dos artigos que Broca escrevia em O Estado de S. Paulo (1956-1961) quando era o responsável pela sessão homônima do suplemento literário desse jornal, e que além disso, o livro não segue nenhum recorte temático específico. Nele podemos encontrar um pouco de vida literária, entretanto, a função de Brito Broca nesse suplemento era a de divulgar as obras que estavam sendo publicadas na França.

Uma pequena parte dessas crônicas encontra-se reunida no presente trabalho em que se investigam as relações culturais entre Brasil e França. Existem, no entanto, outras tantas que abordam a vida literária no contexto francês, mas que não puderam ser estudadas aqui em razão do recorte temático da pesquisa.

Dessa forma, vale considerar que se as crônicas literárias de Brito Broca contribuíram para o entendimento das relações entre literatura e sociedade no Brasil, certamente poderão nos auxiliar da mesma forma em relação à França, uma vez que a crônica, como afirma 
Antonio Candido, "está sempre ajudando a estabelecer ou restabelecer a dimensão das coisas e das pessoas". (CANDIDO, 1992, p.14) 


\section{Fortuna crítica}

(...) todos lhe queriam bem e muitos lhe devem alguma coisa. (Carlos Drummond de Andrade)

Vários estudiosos que já se debruçaram sobre a obra de Brito Broca como cronista literário encontraram marcas singulares que o apontam como um grande conhecedor e, sobretudo, pesquisador da nossa literatura. Não somente da literatura brasileira, como também da estrangeira, especialmente a francesa, como afirma Homero Senna em seu prefácio para Papéis de Alceste (SENNA, 1991, p.9)

A atividade como jornalista profissional teve início quando, em 1927, afastou-se de sua terra natal por redigir uma crônica num órgão oposicionista ao Partido Republicano Paulista (PRP). Transferiu-se, assim, para São Paulo, onde ingressou como colaborador efetivo na redação d' A Gazeta, assumindo o pseudônimo de Lauro Rosas. Mais tarde, tornouse repórter e depois cronista desse mesmo jornal, no qual iniciou um projeto de maior fôlego, recolhendo material sobre literatura e vida literária, tema em que se tornou especialista. Em 1937, mudou-se para o Rio de Janeiro e passou a trabalhar na sucursal do jornal paulista. É esse o período em que se dedica exclusivamente ao jornalismo literário, chegando a ocupar importantes postos em redações de suplementos e revistas especializadas, como Cultura Política, A Manhã, Jornal de Letras, Correio da Manhã e Revista do Livro. Na José Olympio Editora atuou como redator.

O nome do cronista tornou-se familiar nas rodas letradas daquele período (1940 1960). Em 1944 publicou Americanos, livro editado em Curitiba pela Guaíra, na série "Caderno Azul”, coleção dirigida por Sérgio Milliet. Entretanto, foi em 1956, ano da publicação de A Vida Literária no Brasil - 1900, pela José Olympio, que Brito Broca teve seu trabalho reconhecido pelo público, recebendo naquele mesmo ano quatro prêmios importantes $^{6}$. Em 1957 publicou Horas de Leitura e Machado de Assis e a politica, fruto da

\footnotetext{
${ }^{6}$ Prêmio Paula Brito, da Secretaria de Educação do Rio de Janeiro; prêmio Fábio Prado, da Sociedade Paulista dos Escritores; prêmio Sílvio Romero, da Academia Brasileira de Letras; prêmio Luísa Cláudio de Sousa, do PEN Clube do Brasil.
} 
reunião dos artigos esparsos em jornais e revistas. Ainda se preparava para uma terceira antologia (Pontos de Referência) quando, vítima de um atropelamento, morreu em 20 de agosto de 1961, no Rio de Janeiro.

Francisco de Assis Barbosa, amigo e conterrâneo de Brito Broca, foi responsável pela organização de suas Memórias que, a partir de manuscritos e artigos deixados pelo cronista, foram publicadas pela José Olympio em 1968. Da mesma forma o fez com Letras Francesas, em 1969. Nesse trabalho publicado pelo Conselho Estadual de Cultura reúnem-se as crônicas produzidas por Broca no período em que ele colaborou no "Suplemento literário" d' O Estado de S. Paulo, compreendido entre os anos de 1956 a 1961.

Outro colaborador na reunião dos escritos deixados por Brito Broca foi Alexandre Eulálio. Também amigo e grande admirador do cronista, ele objetivava reunir a obra do escritor em 16 volumes, através do projeto "Obras Reunidas" que teve início através da Editora Polis, de São Paulo, em convênio com o Instituto Nacional do Livro. No entanto, falecendo em 1988, o trabalho idealizado e iniciado por ele não resultou em mais do que três volumes: Românticos, pré-românticos, ultra-românticos (1979); Ensaios da mão canhestra (1981); e Machado de Assis e a política (1983).

No ano de 1990, o CEDAE (Centro de Documentação Cultural Alexandre Eulálio), do IEL/UNICAMP, sob a coordenação do professor Francisco Foot Hardman, passou a dar continuidade ao projeto "Obras Reunidas", conseguindo estabelecer um acordo entre as editoras Polis e da UNICAMP para a publicação, em 1991, de Papéis de Alceste, coletânea das crônicas de Brito Broca do período em que escrevia para o jornal A Gazeta, em São Paulo. Outro volume editado no mesmo ano é o organizado por Luiz Dantas, Naturalistas, parnasianos e decadistas. A editora da UNICAMP, ainda no mesmo ano de 1991, assumiu a responsabilidade pela continuação do projeto e realizou, na própria Universidade de Campinas, o Seminário Brito Broca: Vida Literária \& História Cultural. O encontro resultou em mais um número da revista do Departamento de Teoria Literária, o $11^{\circ}$ volume de Remate de Males. 
Essa revista, assim como os prefácios aos livros de Brito Broca, são as primeiras publicações a discutir o trabalho do cronista. Pesquisas de cunho acadêmico ${ }^{7}$, como esta, no entanto, começam a fornecer outros recortes de sua obra.

A maioria dos pronunciamentos feitos a respeito de Brito Broca parte daqueles que já desenvolveram (ou ainda desenvolvem) estudos literários dentro da esfera acadêmica. Dessa forma, trazem consigo uma bagagem de conhecimento construída sobre base sólida, cuja formação passou a contar, sobretudo depois da criação da Universidade de São Paulo, com teorias e métodos científicos mais precisos. Essa geração de críticos passa a comportar outros padrões de referência teórica, os quais surgiram como frutos da formação universitária proporcionada pelos professores estrangeiros, sobretudo os da França, que para cá vieram a fim de fundar a universidade paulista. Antonio Candido, Décio de Almeida Prado e outros são representantes dessa geração souberam capitalizar as demandas de seu tempo e interpretá-las numa chave renovada na qual se mesclavam teoria, método e pesquisa.

Em contrapartida, o trabalho realizado por Broca se vincula ao jornal, o que equivale dizer que seu projeto crítico pautava-se muito mais nas suas "horas de leitura" e no seu autodidatismo, como muitos de sua época, do que em alguma corrente crítica. Brito Broca, portanto, teria se guiado pelo próprio faro, criando assim, à sua maneira, métodos de pesquisa que lhe renderam algumas considerações.

Nesse sentido, as reflexões do prefaciador de Machado de Assis e a política, Silviano Santiago, são bastante pertinentes. Ele sustenta a ideia de que

\footnotetext{
A mais séria e equivocada objeção que se pode fazer ao trabalho crítico de Brito Broca é a de que falta à sua descrição, apreciação ou avaliação da obra literária, certa sistematicidade, característica esta básica da crítica militante universitária. (SANTIAGO, 1983, p.9)
}

Ele atribui essa falta ao meio de divulgação que o cronista utilizou (suplementos literários ou revistas culturais), à linguagem exigida por esse meio (estilo jornalístico) e ao tipo de leitura dispensada ao jornal (leitura ocasional, em diagonal). Defende também a tese

\footnotetext{
${ }^{7}$ Há, até o momento, pelo menos duas dissertações de Mestrado que enfocam o trabalho de Brito Broca: As "Letras Francesas" do Suplemento Literário OESP: dois momentos, duas leituras (2001), de Nelson Luís Barbosa; e Memória, ficção e aforismos: o cronista Brito Broca em formação (2008), de Paulo José de Castro Andrade.
} 
de que esses três fatores não são comuns dentro da tradição moderna da literatura, para a qual o livro, afirma, ainda é sinônimo de qualidade especulativa. O pensamento do cronista apresentava-se de "forma despedaçada" em razão da publicação periódica de seu trabalho, bem como ao curto espaço dedicado a ele nos jornais em que escrevia.

Outra peculiaridade destacada por Santiago consiste no fato de que Broca serviu-se da crônica para tecer parte de sua obra. Lembrando que a efemeridade é um traço caracterizador desse gênero, considera-se que somente com um trabalho sério de pesquisa é que o cronista conseguiu fazer com que sua obra permanecesse viva nos dias de hoje. Ainda com Santiago, vemos que

\footnotetext{
Meio, estilo e leitura são pouco propícios a um trabalho de fôlego e risco dentro da tradição moderna da literatura. Esta, em geral, nas suas obras de mais rendimento estético, eficácia social ou pertinência crítico-interpretativa, tem recorrido necessariamente ao livro - e ao estilo, composição e leitura dele decorrentes. Se meio, estilo e leitura são pouco propícios à alta qualidade da especulação, isto não quer dizer que foram barreiras instransponíveis para Brito Broca. Pelo contrário. (SANTIAGO, 1983, p.9)
}

Santiago se refere aqui ao processo fragmentador ao qual Broca teria submetido seu trabalho que, tendo como suporte a crônica e seu meio de divulgação o jornal, foge do exercício da exegese de obras literárias dentro das páginas do livro. Silviano Santiago acredita que é possível observar a postura crítica de Brito Broca quando se lê seus artigos seguidamente, e não de forma segmentada. É isso, pois, que o faz ao comparar os textos produzidos pelo cronista sobre a postura política de Machado de Assis em períodos diferentes da vida do autor, examinando o salto qualitativo e a coerência de seus textos que, segundo Santiago, retira-o do universo inútil dos descartáveis na medida em que percorre sequencialmente suas crônicas.

O mesmo Silviano Santiago que, no prefácio do livro sobre Machado de Assis é um defensor do "método" de Brito Broca, é também o que promove uma severa crítica a ele em um dos $\operatorname{artigos}^{8}$ da revista Remate de Males. O professor e crítico afirma sua decepção diante dos artigos do cronista que versam sobre a literatura francesa, recolhidos por Alexandre Eulálio. Questionando tanto os autores elencados por Broca quanto o modo de tratar os temas relacionados à literatura francesa, Santiago diz que o cronista não dá o devido valor a autores

\footnotetext{
8 "Lenha na fogueira (leituras em francês de Brito Broca)." Remate de Males, Campinas, (11): 61-66, 1991.
} 
e obras "fundamentais e nitidamente universais daquele país", fato que pode causar reparo no "leitor mais exigente e entusiasmado". Dessa forma,

Nem especialista nem deslumbrado, Brito Broca busca lenha na literatura francesa para aumentar o brilho da sua produção crítica. Por isso, ele é obsessivo na escolha dos temas e questões a serem tratados e personaliza de maneira radical a seleção de autores e obras. (SANTIAGO, 1991, p.64)

Santiago afirma que Broca "só se interessa no outro pelo que já é seu." Quando comenta um livro "alheio, empresta-lhe o que de melhor já possui", quando se refere a outro mais conhecido "retira o que pode enriquecer ainda mais o que já é rico pelo seu próprio talento." Dessa forma, conclui Santiago, estabelece um diálogo com a literatura francesa na procura "daquilo que já ressalta no seu sistema crítico".

Outra consideração do professor diz respeito ao processo de "hierarquização" estabelecido pelo cronista. Segundo Santiago, Broca "interessa-se mais pela 'vida literária' e pelos que a fazem ou a deixam de fazer, do que pelos textos artísticos propriamente ditos." (SANTIAGO, 1991, p. 64)

O embate do qual não é possível escapar quando se toma a obra de Brito Broca diz respeito ao surgimento da crítica universitária no país, a qual até 1930 era praticamente toda realizada nos suplementos literários e nas revistas especializadas. Note-se ainda que o trabalho que Brito Broca desenvolveu configura o que se denomina crítica impressionista. No entanto, esse tipo de crítica, que se baseia nas impressões pessoais face à obra literária ou mesmo na atenção aos fatos exteriores a esta, passa a ser o grande ponto de divergência entre os estudiosos dos fenômenos literários daquele período. É o que podemos verificar nas palavras de Nelson Luís Barbosa9

A moderna crítica literária brasileira, pode-se dizer, tem seu início nos anos que sucederam o movimento modernista como consequência das transformações culturais que sacudiram o país naqueles não tão longínquos anos 20 e 30. Os desdobramentos do movimento modernista, já em estado de acomodação nos anos 30-40, revelaram-se extremamente criativos, dando origem a uma geração de críticos com uma concepção renovada da cultura nacional, agora não mais pautada pelo caráter especulativo e impressionista que até então caracterizara o pensamento brasileiro, tal como se pode constatar nas obras de Sérgio Buarque e Gilberto Freyre,

\footnotetext{
9 Autor da dissertação As "Letras Francesas" do Suplemento Literário OESP: dois momentos, duas leituras. Neste estudo, o autor compara os períodos em que Brito Broca e, posteriormente, Leyla Perrone-Moisés escreveram no Suplemento Literário do jornal $O$ Estado de S. Paulo. O estudo também aborda as diferenças entre a crítica impressionista e a crítica universitária no tratamento da literatura francesa.
} 
e na crítica literária praticada por Sérgio Milliet e Álvaro Lins, por exemplo. (BARBOSA, 2001, p.15)

A respeito disso, o próprio Brito Broca chegou a tratar do assunto em uma entrevista a Ruth Silver ${ }^{10}$. Quando questionado sobre sua posição a respeito das correntes críticas que se debatiam na época, Broca afirma que era "em caráter jornalístico" que tomava conhecimento da atualidade literária e que, por isso, nem sempre podia "opinar com segurança." Afirma-se "visceralmente cético com relação à chamada critique des vivants", pois acreditava que "só a perspectiva histórica coloca [os escritores] no verdadeiro lugar.” Em relação ao debate entre a crítica universitária, a crítica científica e a crítica impressionista, diz o seguinte: "não posso, naturalmente, negar a importância da primeira, mas uma vez que ela seja feita em revistas e em livros." (BROCA, 1993, p.85)

Brito Broca acreditava que só se podia fazer crítica impressionista em "rodapés semanais de jornal”, pois a crítica universitária, "pelo seu próprio caráter, exige um estudo muito mais profundo da obra criticada, a consulta a várias fontes”, coisa que seria inviável para aquele que escreve semanalmente, “já que todos os críticos possuem outras ocupações”. Em relação à crítica científica, afirma ser interessante uma "revisão da obra de Hennequin", o responsável na França pelas "bases da critique scientifique, que viria atender às solicitações do cientificismo do século XIX.”

A comprovação de que uma crítica dentro dos moldes acadêmicos está para o livro assim como a crítica impressionista está para o jornal foi dada, de certo modo, por Brito Broca. É possível verificar a dimensão que suas crônicas alcançam quando saem das páginas do jornal e, após uma revisão, vão para o livro. Em A vida literária no Brasil, por exemplo, Brito Broca revisita alguns de seus textos que foram primeiramente veiculados na imprensa, acrescenta-lhes outras informações (incluindo aí, na maioria das vezes, as referências bibliográficas), de maneira que depois, mesmo que ainda reconheçamos alguns traços da crônica, podemos notar-lhe o esforço para esclarecer possíveis dúvidas que anteriormente foram criadas.

Antonio Candido, no prefácio feito a Ensaios da mão canhestra, ressalta a habilidade de Brito Broca em narrar fatos (história ou biografia) enriquecidos com detalhes

10 "Entrevista a Ruth Silver", em Escrita e vivência. Campinas, SP: Editora da UNICAMP, 1993, p.82-5. 
significativos. Lembra ainda que "o texto como construção linguística, mesmo sendo o fulcro não é tudo para a curiosidade do crítico e sobretudo do leitor." (CANDIDO, 1981, p.8) E em seguida conclui:

Estes perigos não existem no conhecedor Brito Broca, que poderá pecar por omissão analítica, mas nunca na qualidade de "cronista" altamente qualificado. A não ser por um pudor às vezes excessivo quando se trata de discriminar as fontes que usou e foram, por assim dizer, dissolvidas e incorporadas na síntese descritiva. (CANDIDO, 1981, p.8)

Candido lembra que essa postura poderia "causar reparo num estudo de corte erudito e universitário", mas acaba atribuindo tudo "à elegância ensaística de uma exposição que quer ser o mais aliviada possível de qualquer exibicionismo". O crítico continua, dizendo que

No fundo, significa discrição e modéstia, vontade de não parecer pedante nem sobrecarregar a página, - ou seja, as mesmas qualidades que aparecem nos outros níveis de exposição, fazendo, como já foi sugerido, o ponto de vista pessoal parecer uma simples decorrência do material apresentado, e organizado de maneira a destilar por si a interpretação dos significados. (CANDIDO, 1981, p.8)

Os escritos de Brito Broca, segundo Antonio Candido, talvez "não satisfaçam aos que limitam a crítica à análise sistemática e altamente técnica dos textos.” Em contrapartida,

(...) há de satisfazer aos que gostam também da literatura na sua enorme complexidade e variedade, aos que se deleitam e aprendem com o cenário da vida literária, as personalidades dos que produzem os textos e as circunstâncias em que estes são produzidos. (CANDIDO, 1981, p.10)

Dentro dessa perspectiva suscitada por Antonio Candido, Brito Broca distingue-se do "típico cronista". Isso ocorre em razão de um novo direcionamento dado por ele a esse gênero, pois em seus registros é possível encontrar desde o comentário de obras de grandes autores até fatos corriqueiros da vida literária. Isso demonstra que os critérios norteadores dos julgamentos estéticos que tradicionalmente caracterizam a crítica universitária talvez não sejam partilhados por Broca.

Alexandre Eulálio, prefaciador de Românticos, pré-românticos, ultra-românticos, comenta que:

O lugar que Brito Broca ocupou na literatura brasileira foi de certa forma único. Pesquisador por vocação, encaminhou-se naturalmente da divulgação jornalística para a erudição genuína; transformou assim instintivamente a curiosidade virtual (que o havia levado desde cedo às primeiras leituras de artigos de Enciclopédias) na pesquisa cada vez mais aprofundada e absorvente da realidade cultural brasileira, passada e presente. (EULÁLIO, 1979, p.9). 
Traçando um panorama da atuação de Brito Broca, Eulálio acredita que o trabalho do cronista tanto pela "variedade" quanto pela "qualidade e abundância", "constituirá autêntica surpresa, mesmo para os críticos mais céticos e exigentes." Lembra que apesar da "vida atribulada de jornalista profissional e autoditada", Broca não deixou "obra menos decisiva, cuja importância será avaliada na sua verdadeira transcendência (...) reunida em volume.”

A respeito das declarações prestadas até aqui, acreditamos que seja correto afirmar que se o nome de Brito Broca permanece entre os grandes colaboradores dos estudos literários no Brasil provavelmente se deve em razão de sua intensa dedicação à pesquisa que, mesmo com os limites que o suporte de seus textos podiam lhe impor, conseguiu transmitir o teor de alguns aspectos da literatura, sobretudo o da vida literária. 
PARTE II

RELAÇÕES CULTURAIS BRASIL-FRANÇA 


\section{CAPÍTULO II}

\section{BRASILEIROS NA FRANÇA}

Domingos Borges de Barros e Delille (1805)

Intitulada "Domingos Borges de Barros em Paris", essa crônica de 1952, reunida em Românticos, pré-românticos, ultra-românticos, destaca, dentre outras coisas, as "relações intelectuais" entre Domingos Borges de Barros, o Visconde de Pedra Branca, e o poeta francês Delille ${ }^{11}$. Segundo Broca, o brasileiro teria sido um dos primeiros escritores a visitar Paris, embora afirme que Matias Aires, autor de Reflexões sobre a vaidade dos homens, também já o teria feito sem, no entanto, registrar qualquer contato com escritores franceses. Broca cuida também da estreita relação entre Borges de Barros e o escritor português Filinto Elísio, à época, exilado em Paris para escapar da Inquisição.

No que diz respeito à sua estrutura, essa crônica permite-nos identificar um pouco da sistematicidade dos textos de Brito Broca. Os parágrafos iniciais, sobretudo o primeiro, irão confluir a um breve resumo da vida de Domingos de Borges de Barros, como se o cronista quisesse dispor a seus leitores informações elementares que tornasse seu texto inteligível independentemente do nível de conhecimento sobre o assunto.

(...) Borges de Barros estudou em Paris, mas enquanto daquele [Matias Aires] não se sabe que haja travado conhecimento com qualquer escritor francês, deste se tem notícia das relações intelectuais que manteve com o poeta Delille. Baiano, filho de

\footnotetext{
${ }^{11}$ Jacques Delille (Clermont-Fernand, 1738 - Paris, 1813) foi um poeta francês, cujo reconhecimento veio, no entanto, após a tradução das Géorgiques, de Virgílio, publicada em 1770. Em 1774 foi eleito membro da Academia Francesa, embora sua obra mais célebre Jardins tenha sido publicada somente em 1782. Sua poesia caracteriza-se pelo talento descritivo, segundo o qual o poeta deve encontrar as perífrases mais elegantes para descrever coisas simples.
} 
senhor de engenho, Borges de Barros partiu adolescente para a Europa, a fim de cursar a Universidade de Coimbra. Ali bacharelou-se em Filosofia, curso que então envolvia também o estudo das ciências físicas e naturais. E querendo aperfeiçoar-se nesta última matéria, cujo ensino era deficiente em Coimbra, resolveu, depois de receber grau, transferir-se para França. Isto pelos anos de 1805 quando a sombra de Napoleão se estendia por toda a Europa. Em Paris, ao mesmo tempo que se pôs a frequentar os cursos de Cuvier e outros especialistas no Museu do Jardim das Plantas, continuou a cultivar a poesia, para a qual sempre tivera inclinação. (BROCA, 1979, p.35)

É este tipo de organização que verificamos em muitos de seus relatos, ou seja, o breve gesto para situar o leitor ao tema suscitado e, dessa maneira, colocá-lo inteiramente à soleira de suas ideias, e que, outrossim, nos possibilitará perceber o tom didático de seu discurso.

Em função do espaço que o texto de Brito Broca ocupava nos jornais, neste trecho somos levados ainda a observar o caráter sintético de sua escrita, mostrando sempre sua preocupação em captar com poucas tintas o quadro histórico que a temática de suas crônicas traziam. Assim, ao esclarecer que Borges de Barros se encontrava na França nos "anos de 1805 quando a sombra de Napoleão se estendia por toda a Europa", Broca está lembrando ao leitor do agitado período em que se encontrava o velho continente em razão do plano de expansão territorial francês, liderado por Napoleão I que esteve no poder durante dezesseis anos.

De volta ao conteúdo propriamente dito, veremos que o interesse do cronista nesse artigo incide, de modo geral, sobre as relações de um escritor brasileiro com a capital francesa. Por conseguinte, nenhum movimento da vida literária de Barros será deixado de lado. Para iniciar a conversa, Broca relata as afinidades existentes entre Borges de Barros e o português Filinto Elísio ${ }^{12}$, que também se encontrava em Paris. Assim, comenta o cronista, uma vez que o brasileiro era um admirador da poesia,

Nada mais natural, portanto, de que no ambiente de Paris esse gosto se desenvolvesse, sobretudo pelos estímulos que Borges de Barros confessa haver recebido do poeta Filinto Elísio, ali exilado. (BROCA, 1979, p.35)

Broca não consegue identificar as condições em que os dois teriam se aproximado. Conta apenas que Filinto Elísio havia fugido "rocambolescamente da Inquisição, em Lisboa,

\footnotetext{
12 Pseudônimo de Francisco Manuel do Nascimento (1734-1819) que, além de sacerdote, foi também um dos mais importantes poetas neoclássicos de Portugal e tradutor de autores como Chateaubriand e de La Fontaine. Sofreu grande influência de ideias iluministas, fato que o levou a ser perseguido pela Inquisição em 1778 e que o impeliu ao exílio na França.
} 
conseguindo (disfarçado em marinheiro) tomar um navio que velejou para a França" (Ibidem, p.35). Informa ainda que, uma vez exilado, o poeta português fora tomado por grande nostalgia da terra natal, mantendo-se "insensível e numa indiferença quase hostil aos encantos de Paris". Segundo Broca, Filinto Elísio foi, "entre os escritores e poetas estrangeiros que têm conhecido Paris, um dos únicos a não amar a cidade" (Ibidem, p.36).

Broca estende-se mais um pouco a respeito das relações entre os dois escritores. Segundo ele, quando Borges de Barros se aproximou de Filinto Elísio, este já sabia da tradução de uma passagem da Histoire philosophique et politique des établissements et du commerce des Européens dans les deux Indes, de Raynal ${ }^{13}$, "autor então em voga pelas suas ideias esclarecidas." Broca aproveita para comentar o fato de parecer estranho traduzir-se em verso uma história filosófica, embora logo adiante defenda o escritor, alegando que "naquela época estava em moda a poesia didática, de que Delille se tornara na França uma das maiores figuras."

Após receber críticas positivas de seu trabalho, Borges de Barros aproximou-se ainda mais de Filinto Elísio, a ponto de visitá-lo com frequência durante todo tempo que esteve em Paris. Quando finalizou a tradução, "se entregou a outros trabalhos poéticos com maior ardor", sempre com a ajuda do mestre, ligando-se a ele por "verdadeiros laços de amizade, a ponto de mais tarde, de regresso ao Brasil, ter-lhe enviado auxílio financeiro."

A amizade com Filinto Elísio, de acordo com Broca, ocorre ao mesmo tempo em que Barros procura aproximar-se de Delille, "cuja obra muito admirava." O brasileiro chegou a fazer-lhe duas visitas, "delas nos dando conta num fragmento autobiográfico", cuja referência o cronista não explicita claramente em seu texto. $\mathrm{Na}$ primeira delas, Barros objetivava convidar Delille a traduzir Camões para o francês, vingando a memória deste das "injustiças com que temerariamente o deslustrara Voltaire ${ }^{14,}$ (grifo nosso). Segundo Broca, Borges de Barros

\footnotetext{
${ }^{13} \mathrm{Na}$ crônica lê-se Histoire philosophique des établissements et du commerce des Européens dans les deux mondes. Note-se ainda que a tradução de Borges de Barros parece não ter sido editada visto que não encontramos nenhuma referência.

${ }^{14}$ Aqui faz-se alusão à severa crítica feita por Voltaire ao trabalho de Camões em L'Essai sur la poésie épique, publicado em 1882, antecedido do poema La Henriade. Segundo o discurso preliminar de Thomas José de Aquino de 1818, encontrado também na edição de 1865 de Os Lusíadas, Voltaire teria tomado conhecimento da
} 
Apresentou-se sem recomendação e foi muito bem recebido. Iniciada a palestra, veio à baila o nome de Camões, e o jovem brasileiro pôde constatar, desde logo, que Delille tinha a respeito do poeta português ideias errôneas, semelhantes às de Voltaire. (BROCA, 1979, p.36)

Com efeito, a conversa com o francês mostrou-se bastante produtiva visto que "Delille acabou convencido e declarando-se pronto a traduzir várias passagens de Camões", como afirma Broca.

Na segunda visita, o brasileiro queria mostrar-lhe "a tradução de Plantas de Castel, feita por Bocage, para que o francês fizesse uma ideia da língua de Camões, computando os versos" (Ibidem, p.37). Aproveita a oportunidade para mostrar também um exemplar do escritor português, traduzindo-lhe algumas oitavas que o surpreendem, colocando-se à disposição de Delille para traduzir o que ele "quisesse pôr em verso francês." Broca finaliza o tema "Delille" relatando que essas duas visitas haviam deixado o brasileiro encantado com o escritor, mas que, como se depreende, a amizade não poderia se avultar por causa da idade avançada do poeta que "via-se condenado à cegueira e sofria de "uma cruel paralisia ou convulsão'."

A partir desse ponto, a crônica ganha outro rumo. Broca relata a seus leitores os momentos de turbulência pelos quais Borges de Barros terá de passar em virtude da "invasão de Portugal pelos exércitos napoleônicos, com a consequente fuga da Família Real lusa para o Brasil” que, segundo o cronista, "deixava o estudante, enquanto súdito português, em situação dificílima na França" (Ibidem, p.37).

A invasão a Portugal ocorre, conta-nos Broca, no momento em que Borges de Barros realizava uma viagem à Alemanha. Rompidas, portanto, as comunicações entre o Brasil e a França, o brasileiro ao retornar a Paris não pôde mais receber a mesada do pai, um senhor de engenho na Bahia. É nesse período, afirma Broca, que Barros se empenha na elaboração de um dicionário portátil francês-português e português-francês como meio de obter recursos para sua sobrevivência. A empreitada se realizaria juntamente com o também português

obra camoniana por meio de uma tradução inglesa feita por Ricardo Fanshaw em que esta "não representa o seu original com fidelidade; pois além de não ter espírito poético algum, tem vários equívocos, conceitos, e expressões baixas, que não se acham no original, os quais, porém, o desavergonhado Voltaire, com mão liberal dá todos a Camões.” (AQUINO, 1865, p.8) 
Abade Corrêa da Serra, não fosse este ter sido acometido por uma doença, ficando todo o trabalho a cargo do brasileiro.

Segundo Broca, sobre o episódio das "aperturas em Paris", existem relatos tanto no livro do brasileiro, Poesias às senhoras brasileiras, quanto nas Obras completas de Filinto Elísio, assunto de uma de suas "enumerações caóticas" em verso. Broca comenta o caso na crônica sem lá transcrevê-lo. Aqui o reproduzimos parcialmente, após consulta ao livro do poeta:

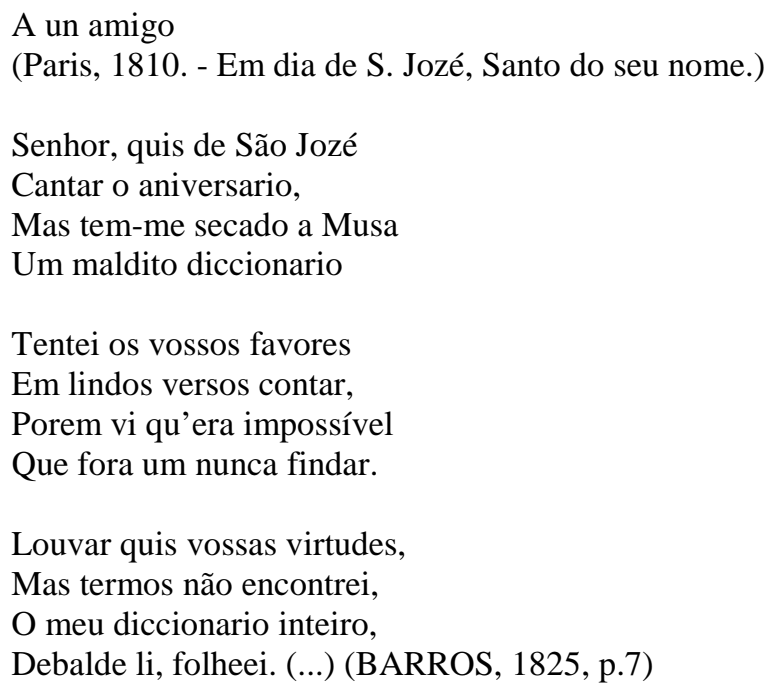

Como podemos conferir, o incidente ocorrido com Borges de Barros atingiu-o de modo tão certeiro que chega a repercutir em sua poesia. Neste trecho, verificamos o poeta envolto por seu labor de tal forma que sua inspiração secara em virtude da confecção de um "maldito diccionario" que lhe tomava todo o tempo.

Finalizando sua crônica, Broca relata ainda que Borges de Barros, após ter vencido outras dificuldades, consegue permissão para retornar ao Brasil, passando primeiramente pelos Estados Unidos, onde permaneceu algum tempo antes de regressar de vez à sua pátria. Entretanto, comenta Broca, "a circunstância de haver permanecido na França e a passagem pelos Estados Unidos tornava-o suspeito de colaboracionismo com Napoleão. Em razão disso, foi preso na Bahia e transferido para o Rio" (Ibidem, p.37). O poema "Cantigas improvisadas" também registra a angústia do poeta ao ser renegado em sua pátria. Brito Broca

\footnotetext{
${ }^{15}$ Segundo Broca, em outubro de 1811 foi publicada a decisão judiciária que inocentava Domingos Borges de Barros.
} 
reproduz apenas uma parte dele possivelmente em razão do pouco espaço reservado à sua crônica no jornal.

Brito Broca afirma que sua intenção ao tocar no nome de Borges de Barros era apenas de assinalar "as circunstâncias que o tornaram o primeiro poeta brasileiro a fazer (por assim dizer) vida literária em Paris". Essas notas sobre uma "existência bem romanesca", espera ele, foram feitas com a intenção de tentar os biógrafos. 
A vontade de escrever um livro cujo tema seria a presença de escritores brasileiros na França é algo muito forte em Brito Broca. No artigo "Natividade Saldanha no exílio", de 1952, recolhido também em Românticos, pré-românticos, ultra-românticos, logo de partida o cronista manifesta esse desejo:

Sob o título Escritores brasileiros em Paris, poder-se-ia escrever um livro fascinante, que iria desde José Bonifácio, nos fins do Século XVIII e Caetano Lopes, nos começos do Oitocentos, até Dinah Silveira de Queiroz, autografando os exemplares de L'Ile des Demons, na Casa Julliard. Que sequência palpitante de episódios não apresentaria tal livro, no qual se reuniriam passagens biográficas de muitas vidas dramáticas e pitorescas! (BROCA, 1979, p.46)

Broca, entretanto, acredita que entre os capítulos mais curiosos de tal obra o dedicado ao poeta pernambucano José da Natividade Saldanha seria o mais curioso. Se por um lado a obra desse escritor é de pouco interesse para os pesquisadores, afirma ele, o mesmo não se pode dizer de sua biografia “interessantíssima”. Dessa forma, o que Brito Broca irá oferecer ao leitor dessa crônica é um breve relato das aventuras de um audacioso escritor - desde sua participação na Confederação do Equador, seguida de sua passagem por terras norteamericanas e a tumultuada estada na França de Charles X, até chegar à Inglaterra, de onde partiu depois para a Venezuela.

Nascido em Recife no dia 8 de setembro de 1796, filho do vigário João José Saldanha Marinho e da mulata Lourença da Cruz, Natividade Saldanha foi aluno do seminário de Olinda e em 1819 seguiu para Portugal. Formou-se em Direito pela Universidade de Coimbra e em 1823 retornou ao Brasil, onde passou a advogar.

Os tempos eram de incerteza política. A Constituição de 1824, promulgada por Dom Pedro, definia o governo brasileiro como monárquico, hereditário e constitucional. Seguindo o molde francês de separação do Poder Moderador do Poder Executivo, criado por Benjamin Constant de quem o imperador era leitor assíduo, Dom Pedro acabou por concentrar várias atribuições em suas mãos, dentre elas: nomear senadores, dissolver a Câmara e convocar eleições para sua renovação e sancionar ou vetar as decisões da Câmara e do Senado. Em Pernambuco, entretanto, local onde a propagação das ideias republicanas, antiportuguesas e federativas ganhava ímpeto graças à efervescência vivida ainda pela Revolução de 1817, a 
atitude do monarca teve outra dimensão. Assim, em resposta à nomeação de um governador não-desejado, no dia 2 de julho de 1824 proclamou-se a Confederação do Equador que reuniria sob a forma federativa e republicana, as províncias da Paraíba, Rio Grande do Norte, Ceará, Piauí e Pará - além, evidentemente, de Pernambuco -, tendo Manuel de Carvalho Paes de Andrade como seu chefe ostensivo, Natividade Saldanha como secretário de seu governo e José de Barros Falcão de Lacerda no comando militar. O levante, todavia, em virtude da supremacia militar das tropas do governo, teve fim, após várias derrotas nas províncias, em novembro de 1824.

À Confederação do Equador, Brito Broca atribui o que teria sido o período mais dramático da vida de Natividade Saldanha que, fracassado o movimento, fugiu para os Estados Unidos, onde acabou sofrendo com o preconceito racial:

(...) ao chegar à Filadélfia começam os contratempos. Mulato, Natividade Saldanha teve fechadas as portas do primeiro hotel a que se dirigiu. Em Nova York sentiu ainda maior a pressão do preconceito de cor. Compreendeu, então, que não podia ficar ali. Não encontraria o asilo que buscava. Seu pensamento voltava-se todo para a França, onde já se tinham abrigado tantos brasileiros. (BROCA, 1979, p.46)

O cronista conta em seguida que Natividade Saldanha havia embarcado para França a bordo do navio Bayard. "Era no reinado de Carlos X; Balzac ainda não havia publicado a Comédia Humana" (Ibidem), informa-nos ele, emoldurando em poucas palavras todo o quadro político-social francês daquela época. Além da capacidade de contar o substancial, esse fragmento da crônica aponta também para os infortúnios que Saldanha viria a sofrer.

Há pouco mais de uma década, a França havia passado por mudanças importantes em seu cenário político. Após a segunda derrota de Napoleão em 1815, é instituída novamente a Restauração, trazendo mais uma vez ao comando do país a dinastia dos Bourbons. Luís XVIII garante alguns direitos ao povo criando uma Charte Constitutionnelle; trata-se, portanto, de uma monarquia constitucional que agrada a burguesia. Em contrapartida, os nobres, empolgados com o retorno da monarquia, querem restabelecer o Ancien Régime. Luís XVIII consegue conciliar a situação e manter o equilíbrio. Com a sua morte, seu irmão, Charles X, assume o poder, sagrando-se em Reims, segundo a tradição real do Antigo Regime; em abril de 1827 suprime, entre outros, o direito de liberdade da imprensa, não respeitando mais, portanto, a constituição de Luís XVIII. 
Balzac, é verdade, ainda não havia dado início ao grande projeto que foi La comédie humaine. $\mathrm{O}$ escritor francês é lembrado por Broca justamente porque foi ele que captou em sua obra todo o processo de profundas mudanças pelo qual passava a sociedade francesa na primeira metade do século XIX, evidenciando a transição do Antigo Regime à consolidação da moderna sociedade burguesa.

Assim, pode-se concluir que Broca quis informar seu leitor da atmosfera que aguardava o escritor brasileiro; ou seja, a presença de um foragido político com ideais republicanos possivelmente não seria bem-vinda em um país que há pouco havia restabelecido um regime monárquico.

Desembarcando em Havre, continua Broca, Natividade Saldanha dirigiu-se logo para Paris em uma diligência parecida com a L'Hirondelle descrita por Flaubert em Madame Bovary. Embora falasse mal o francês, o poeta, "um pernambucano expansivo", tratou logo de puxar uma prosa com seu companheiro de viagem, ao qual contou sobre sua situação na França. O que Saldanha não sabia era que a polícia francesa já o procurava, "empenhada em impedir a permanência de elementos indesejáveis no país" (Ibidem, p.47). Broca conta ainda que o companheiro de Saldanha, assim que chegaram à capital francesa, tratou logo de denunciar o estrangeiro.

Em Textos e pretextos, de Alberto Rangel, obra citada pelo próprio cronista, encontrase outros detalhes da chegada do escritor brasileiro à França. Depreende-se primeiramente que Natividade Saldanha havia desembarcado em solo francês no dia 7 de janeiro de 1825 e que prosseguira sua viagem até chegar em Paris no dia 16, juntamente com Leão Tisset, seu delator. Verifica-se ainda que no intervalo entre o desembarque em Havre e a chegada em Paris, a 14 de janeiro, recebia o chefe de polícia uma carta do ministro do interior alertando-o de que se deveria cuidar para que o brasileiro se estabelecesse numa cidade no interior da França.

Numa das reproduções feitas por Alberto Rangel sobre o caso Natividade Saldanha, lê-se o teor do relato que Léon Tisset havia feito ao chefe de polícia de Bayonna, local onde se dera a denúncia:

"Il (Léon Tisset) parle sans embarras de ses rapports avec Jose Saldanha, qu'il represente comme un homme ardent et une mauvaise tête, et qu'il a vu, dit-il, pour la 
première fois et par hasard sur la route du Havre à Paris, dans une voiture publique, où leur commune connaissanse de la langue portugaise forma entre eux une sorte de liaison accidentale et momentanée." (RANGEL, 1926, p.36-7)

Saldanha, segundo consta, conseguiu hospedar-se num hotel em Paris. Entretanto, a polícia francesa o tem como suspeito e interroga-o. De acordo com Brito Broca, o poeta dá respostas satisfatórias e consegue causar boa impressão às autoridades. Eis um trecho da carta do prefeito da polícia ao ministro do interior reproduzido por Rangel:

\begin{abstract}
“(...) Le sieur Saldanha s'est présenté, il y a deux jours, à ma Préfecture, pour demander un permis de séjour. Interrogé sur les motifis de son voyage à Paris, il a répondu que, fatigué des troubles qui agitaient son pays, il s'était résolu à venir un asile en France et qu'il avait le projet d'employer le temps qu'il y passerait, à étudier la Botannique. Il est à remarquer qu'il entend à peine le français et qu'il a besoin d'un interprète pour comprendre les phrases plus usuelles de notre langue. La physionomie de ce mulâtre est fine et spirituelle et il a une audace et une assurance peu communes. On continnera à le surveiller avec la plus grande attention, mais s'il est chargé de quelque intrigue, je présume qu'il sera d'autant plus difficile de les pénétrer, qu'il sera impossible de se mettre en contact avec lui." (RANGEL, 1926, p.38-9)
\end{abstract}

Não obstante, o governo francês, temendo revolucionários vindos da América, considerou prudente afastar Saldanha e no dia $1^{\circ}$ de fevereiro de 1825 "o ministro do interior baixava a ordem que atirava o mestiço pernambucano ao caminho do retorno." (RANGEL, 1926, p.39) Broca destaca nessa ação o papel do Ministro do Brasil, e também poeta, Domingos Borges de Barros ${ }^{16}$, o Visconde de Pedra Branca que, segundo ele, "tudo fez para embaraçar a permanência do conspirador fracassado na França.” (BROCA, 1979, p.47)

Assim, no dia 6 de fevereiro daquele ano, sob a ordem do ministro do interior, "Saldanha tem o aposento no hotel varejado pela Polícia, as malas revistadas, sendo lavrado um auto de apreensão, reproduzido por Alberto Rangel no livro Textos e Pretextos" (Ibidem). Broca nos informa de que nada havia sido encontrado dentre os pertences do poeta. No entanto, chama sua atenção as "curiosas" expressões do funcionário encarregado de lavrar o auto. Temos, pois, segundo Broca:

Num maço de papéis, onde se achavam algumas poesias, acentuou ele que nelas brilhavam um "verdadeiro talento", não possuindo sentido político. Em outros versos, porém, de diferentes autores e relativos à matéria política, "o espírito era o pior possível e o estilo detestável”. (BROCA, 1979, p.47)

\footnotetext{
${ }^{16} \mathrm{Na}$ época, era o diplomata responsável por tratar do reconhecimento da independência do Brasil junto ao governo francês.
} 
De acordo com o cronista, os papéis encontrados pela polícia francesa não ofereciam nenhum interesse ao governo. $\mathrm{O}$ que deles podiam extrair era somente a maneira pela qual se dava a transformação de ideias em nosso país: "começara-se por detestar os portugueses da Europa e exaltar Dom Pedro; terminara-se por declarar guerra a toda a monarquia e à população branca" (Ibidem). Dessa forma, Broca acredita que o fato de "Natividade Saldanha ser mulato induzia as autoridades a verem na conspiração em que ele se envolvera uma luta de raças."

Eis o auto lavrado pelo funcionário da polícia francesa, reproduzido por Alberto Rangel, como lembra Brito Broca:

"José da Natividade Saldanha, né le 8 septembre 1795, à Recife de Pernambuco, est mulâtre. Il a été nourri par une indienne. Lui-même donne ces détails dans l'Essai coté $\mathrm{n}^{\circ} 1$, et qui était destiné á devenir le premier chapitre de ses mémoires.

Les certificats d'études et le diplôme don il est porteur, prouvent qu'il s'est distingué à l'Université de Coïmbre, et qu'il y été reçu bachelier en droit, le 9 juillet 1823.

L'éxamen de ses papiers a produit le résultat suivant:

$1^{\circ}$ La liasse cotée $n^{\circ} 1$, ne contient ue l'histoire de son enfance.

$2^{\circ}$ La liasse cotée $n^{\circ} 2$, contient quelques poésie où brillet un véritable talent; mais entièrement étrangers à la politique, ainsi que l'ébauche d'une tragédie d'Atahualpa. En peignant la catastrophe qui précipite du Trône ce dernier souverain du Pérou, l'auteur appelle visiblement sur les européens établis dans l'Amérique la vengeance de Castes indigénes, aux quelles celles des mulâtres s'est constamment associée.

$3^{\text {o Sous le }} \mathrm{n}^{\mathrm{o}} 3$ Saldanha a réuni plusieurs traductions en prose d'auteurs français. Ce sont:

a. Essai sur l'épopée, de Voltaire.

b. Eliézer et Nephtali, de Florian.

c. Essai sur le moyen d'engendrer des Enfants d'esprit, de Lavater.

d. Discours prononcé par Racine, pour sa réception à l'Académie Française.

e. Extrait du traité de Lucien, sur la manière d'écrire l'histoire.

$4^{\circ}$ Livre de comptes, tout-à-fait insignifiant.

$5^{\circ}$ Poésies de différents auteurs trouvées dans les papiers de Saldanha, et complètement étrangères à la politique.

$6^{\circ}$ Poésies de différents auteurs, et rélatives à des matières politiques. L'esprit en est fort mauvais, le style détestable; la traduction des semblables pièces, uniquement relatives aux affaires de Portugal et du Brésil, n'aurait aucun intérêt pour le Gouvernement français; tentent uniquement propager l'anarchie dans le Brésil, et à provoquer la destruction de la population blanche dans cette contrée mais la communication de ses écrits pourrait devenir utile aux légations portugaise et brésilienne.

Il est facile d'observer, en parcourant ces pièces politiques, les changement graduels qui se sont opérés dans les esprits, à Pernambuco, et dans le reste des provinces au nord du Brésil. On a commencé pour invectiver contre les portugais de l'Europe, et pour exalter Don Pedro; on finit par déclarer la guerre à tout pouvoir monarchique, et presque à toute génération blanche. 
$7^{\circ}$ Poésies relatives à des matières politques, et toutes de sa main. L'esprit en est aussi mauvais que celui des précédentes; mais elles sont remplis de verve et de véritable talent. Les observations précédentes leur sont entièrement applicables.

$8^{\circ}$ Essai d'un poème épique, intitulé Joaneida. Le sujet de cet ouvrage serait l'expulsion des hollandais qui s'étaient rendus maîtres, au commencement du XVII ${ }^{\mathrm{e}}$ siècle, de tout le nord du Brésil. Les premières stances font allusion à la vie passée et à l'existence actuelle de Saldanha. Elles respirent un esprit de faction et de haine contre le parti vainqueur dans la dernière guerre civile du Brésil. Enfin, on a trouvé dans les papiers de Saldanha un petit poème imprimé à Lisbonne, et dont l'esprit politique est excellent.

On voit par cette analyse, que les papiers de quelque importance dont Saldanha était muni, sont restés en Angleterre ou à New York. Il me semble qu'on pourrait lui rendre tous ceux qui ont passé sous mes yeux; et qu'en adoptant même le systême de plus sevère, on ne pourrait garder que la liasse cotées 6 et 7, le plan de la tragédie d'Atahualpa et la Joaneida. Paris, le 8 février 1825." (RANGEL, 1926, p.48-53)

Livre finalmente das perseguições na França, Natividade Saldanha segue para a Inglaterra "no dia 12 de fevereiro de 1825, às 9 horas da manhã, no paquete 'La Furie', nome, no caso, de grande significação e propriedade" (Ibidem, p.54). Lá se achava Paes de Andrade, "chefe da insurreição fracassada." Antes disso, lembra Brito Broca, o poeta não provia de recursos para sua partida e, assim, recorreu a alguns brasileiros residentes em Paris e obteve a quantia necessária. O cronista não nos informa quem seriam esses compatriotas, mas Argeu Guimarães, em Vida e morte de Natividade Saldanha, nos presta maiores esclarecimentos. Diz ele:

A França lhe recusava a acariciada hospitalidade. Sem dinheiro, sem documentos, era obrigado a seguir os tortuosos trilhos do exílio. A fina flor dos pernambucanos residentes em Paris, num gesto de comovida solidariedade, abriu uma subscrição para auxiliar a viagem, contribuindo para esse efeito o futuro Boa-Vista, seu irmão Sebastião, depois ministro da guerra e veador; Maciel Monteiro, que seria mais tarde barão de Itamaracá, ministro dos Estrangeiros, o galanteador do Império, o fino diplomata e poeta mundano; Pedro de Araujo Lima, que um dia se chamaria marquês de Olinda, ministro, senador, conselheiro da coroa, regente; o baiano Sequeira Lima, falecido na Venezuela como encarregado de negócios do Brasil, e outros e outros, de nobre descendência. Araujo Lima recolheu as quotas, adiantando as dos colegas pobres... (GUIMARÃES, 1932, p.120-1)

Há ainda outro fato muito instigante no caso Natividade. Em Textos e pretextos, Rangel lembra que o poeta, estando ainda em Paris, encontrou-se com o padre Tavares ${ }^{17}$ :

\footnotetext{
${ }^{17}$ Francisco Muniz Tavares (1793-1876), sacerdote e político, atuou na Revolução Pernambucana de 1817. Foi deputado na Corte de Lisboa em 1821 onde enfrentou forte oposição ao defender os interesses brasileiros. Obrigado a fugir para a Inglaterra, só retornaria ao Brasil em 1822, ano da proclamação de nossa independência; foi eleito no ano seguinte à primeira Assembleia Constituinte Brasileira, logo dissolvida por determinação de $\mathrm{D}$. Pedro I. Recusou-se a participar da Confederação do Equador e foi para a Europa estudar Teologia. Publicou História da Revolução Pernambucana de 1817, em 1840.
} 
Havia encontrado Saldanha em Paris ao seu adversário o padre Francisco Muniz Tavares, o panegirista da Revolução de 1817 , que ali se achava com seu sobrinho, desde os primeiros dias de setembro de 1824. Dizia o prefeito a 15 de abril do ano seguinte que Saldanha dirigira àquele seu comprovinciano uma carta ameaçante "dans laquelle il l'accuse d'avoir provoqué la mesure dont il a été object”. (RANGEL, 1926, p.54-5)

Esta informação restaria desconexa em nossa leitura não fossem as palavras de Argeu Guimarães sobre o caso. Vejamos:

Em toda aquela espionagem e perseguição, contrastando com a generosidade e a piedade da colônia pernambucana, o padre Tavares aparecia, no fundo sombrio do cenário, como delator e traidor. Não tinha perdão para a consciência dos paladinos de 24. Furioso com quem lhe merecera outrora fervoroso panegírico, Natividade, nos passos da expulsão, endereçou-lhe uma carta ameaçadora, acusando-o de haver instigado, as autoridades francesas, de parceria com Pedra Branca, a adotarem a medida inflexível. Mais uma injustiça, mais um desengano que ele não podia admitir nem compreender. (GUIMAR ̃̃ES, 1932, p.123-4)

Não se sabe até que ponto a acusação de Natividade Saldanha é verdadeira. Todavia, fica mais evidente que o poeta creditava também ao padre uma parcela de culpa para sua expulsão da França.

Brito Broca prossegue sua crônica sem, entretanto, relatar um acontecimento trágico na vida de Saldanha: o naufrágio do La Furie. Consultando a obra de Argeu Guimarães, conta-nos ele que Natividade Saldanha

Naufragou, em verdade, no canal da Mancha e perdeu os últimos haveres, os seus papéis amados, as suas roupas, o seu dinheiro, sendo obrigado a trabalhar rudemente para ganhar o pão.

- O naufrágio foi o mais duro transe de toda a minha vida, confessou ele ao amigo Ortiz $^{18}$ nos extremos dias. - Estive a ponto de perecer em frente às costas da Inglaterra, lutando dois dias contra ondas enfurecidas, nu, com uma tábua amarrada à cintura, para quando chegasse o momento supremo do barco submergir. Nesse tempo ainda não se conheciam as boias e salva-vidas de cortiça... (GUIMARÃES, 1932, p.126)

Diante disso, não resta dúvida de que, como destaca Broca no início de sua crônica, em um livro sobre escritores brasileiros em Paris o capítulo dedicado ao poeta pernambucano seria o mais curioso.

\footnotetext{
18 Trata-se de João Francisco Ortiz, colombiano que amparou Natividade Saldanha em Bogotá. Narrou em um livro de reminiscências alguns detalhes da permanência do poeta em Albion.
} 
Prosseguindo nossa leitura, o cronista nos conta que Natividade Saldanha ao chegar à Inglaterra, enviou uma carta "malcriada" ao chefe de polícia de Paris, na qual protestava contra a violência que lá sofrera. Broca comenta que a carta do poeta havia sido escrita em português e terminava com um pitoresco "Bonjour". Vejamos, pois, as palavras do poeta ao chefe da polícia francesa, reproduzidas em Textos e pretextos:

\begin{abstract}
"Mr. Prefeito da Polícia de Paris. Liverpool, 14 de março de 1825, nº 1, Manfields Street.

Como vós não vos contentastes somente com furtar os meus manuscritos durante a minha detenção em Calais, porém agora mesmo (segundo nos conta) furtastes do correio dessa cidade umas cartas, que me vinham dirigidas de Pernambuco e de Coimbra para as remeter ao vosso amigo Borges de Barros, não posso deixar de vos dirigir esta para dizer-vos que me remetais as minhas cartas, e que não continues na vil e infame espionagem, que não perdoa nem ao selo das cartas, contra todos os princípios da Razão e da Justiça, porém nenhuma outra coisa há de esperar de um governo tímido e que está vacilando sobre o trono. Eu sei que vos remetestes os meus manuscritos ao vosso Borges; fizestes bem; eu temo tanto a ele, como vos temo a vós; porém com toda a razão aborreço a ambos. Rogo-vos, que lhe mandei esta minha carta, e que não deixeis de mandar um de vossos espiões para me acompanhar tão bem nesta cidade. Tende saúde e regalai-vos com vossos amigos Borges e Muniz Tavares. Bonjour! J. da N. Saldanha”. (RANGEL, 1926, p.55-6)
\end{abstract}

Tão interessante quanto a própria carta de Saldanha é a consideração que dela faz Alberto Rangel. Em seu livro, diz ele que:

(...) Essa epístola, com efeito, não se reponta em torneios que a sobrelevem. Até a sintaxe saiu arranhada na danação do animal que se escorraçava... Doloroso é que se o verifique: a pena de Saldanha retalhou suas queixas de modo nada literário, senão pouco cavalheiresco. A inteligência também é responsável dos gestos subalternos que ela deixa correr à sua revelia... (RANGELl, 1926, p.56)

Rangel, segundo o cronista, considera as atitudes do poeta como sendo de uma "grosseria inqualificável, bem própria de um mestiço". Broca, no entanto, acredita que tais atitudes refletiam o "desabafo de quem se sentira ferido nos seus direitos".

Vejamos ainda a reação do chefe da polícia de Paris na leitura de Brito Broca:

E o mais curioso é o que nos informa Alberto Rangel. De posse da missiva, o Chefe de Polícia fê-la traduzir e ao inteirar-se dos termos ofensivos, tomou uma resolução realmente deliciosa, pela qual se vê que mesmo os chefes de Polícia da França não são destituídos de esprit: remeteu a carta ao Ministro do Interior com a seguinte nota: “A julgar pelo conteúdo é à Vossa Excelência que o Sieur Saldanha quis dirigir-se". Como bom funcionário, transmitia, assim, a quem de direito os desaforos do Sieur Saldanha. (BROCA, 1979, p.48)

Finalmente em Londres, Saldanha encontra-se com Paes de Andrade e Lacerda. Juntos, premeditavam um plano de investida contra o Brasil monárquico, uma 
"republicanização total do continente" (GUIMARÃES, 1932, p.135). Pensavam em organizar uma expedição naval e para isso necessitavam angariar recursos. Assim, com o intuito de conseguir apoio para o levante, Natividade Saldanha, em maio de 1825, partiu para Caracas, Venezuela, para encontrar-se com Simón Bolivar, um dos principais libertadores da América espanhola.

É importante observar que no Estudo histórico-biográfico de José Augusto Ferreira da Costa $^{19}$, em Poesias de José da Natividade Saldanha, verifica-se que o poeta brasileiro teria partido da Inglaterra para os Estados Unidos com cartas de apresentação dadas por Paes de Andrade, ao contrário do que afirmam Broca e Guimarães; por não encontrar abrigo em solo norte-americano em razão do preconceito racial, é que Natividade Saldanha segue, primeiramente para o México, e só depois para a Venezuela, "onde fixou sua residência, esperando o dia em que pudesse ver a pátria” (COSTA, 1875, p.XC).

Contradições à parte, fato é que Natividade Saldanha continuou fiel à sua personalidade. Conta Broca que, condenado à morte no Brasil, Saldanha enviou da Venezuela uma carta na qual dava procuração a um amigo para que se deixasse fuzilar em seu lugar. É o que também afirma e reproduz Costa no estudo biográfico do poeta. Vejamos:

\footnotetext{
"Pela presente procuração, por mim feita e assinada; constituo por meu bastante procurador na província de Pernambuco ao meu colega dr. Thomaz Xavier Garcia de Almeida, para em tudo cumprir a pena que for imposta pela comissão militar, podendo este morrer enforcado, para o que lhe outorgo todos os poderes que por lei me são conferidos. Caracas, 3 de agosto de 1825. - José Natividade Saldanha". (COSTA, 1875, p.XC-XCI)
}

Nessa mesma ocasião, Saldanha escreve uma carta ao Dr. Pedro Moraes Mayer queixando-se da sentença contra ele aplicada e por este tê-lo chamado de mulato. Assim, lembra ao colega que "esse - tal mulato Saldanha - era o mesmo que adquiria prêmios, quando ele Mayer tinha aprovação por empenhos, quando o tal mulato recusava o lugar de auditor, ele o alcançava por bajulações etc." (Ibidem); e aproveita a oportunidade para enviar também um soneto:

Em vão pretendes, monstro sanguinoso,

Sobre mim desfechar seu golpe injusto:

Fui condenado à morte?... não me assusto;

${ }^{19}$ Organizador do livro em que estão recolhidas algumas das poesias de Natividade Saldanha. 
Não me acobarda teu decreto iroso.

Sim, a pátria perdi, fui desditoso,

Mas vivo sob as leis de um povo augusto,

E o rei dos orbes poderoso e justo

Não tardará de ouvir meu som queixoso.

Une os escravos, que o Brasil encerra,

Invoca as fúrias do tremendo Averno,

Desfaz-te mesmo enfim, nada me aterra.

Há de ser contra ti meu ódio eterno,

$\mathrm{E}$ hei de enquanto viver, fazer-te guerra,

Na terra, e mar, e céu, no mesmo inferno.

(SALDANHA, 1875, p.44)

No livro explicitamente utilizado pelo cronista, Textos e pretextos, não se encontra o detalhe da condenação de Natividade Saldanha e tampouco se transcreve a pitoresca procuração do poeta; foi com o desenrolar da pesquisa que se pode confirmar esse fato relatado por Broca - tanto em José Augusto Ferreira da Costa quanto em Argeu Guimarães. Todavia, se não fosse sua crônica, possivelmente José da Natividade Saldanha permaneceria esquecido - como talvez ainda o seja - pela história da literatura brasileira. Fica, entretanto, a dúvida sobre qual obra Brito Broca teria compulsado para trazer o detalhe, sempre relevante, de seu texto.

Há ainda outro fato que não se encontra nem em Brito Broca e muito menos em Alberto Rangel. Trata-se da morte de Natividade Saldanha. E, sobre o caso, as obras de Argeu Guimarães e de Ferreira da Costa são valiosas fontes de informação.

Verifiquemos, primeiramente, as palavras de Costa:

Temos que Saldanha falecera solteiro, embora haja ele dito na mesma carta a Mayer que era muito bem acolhido na sociedade de Caracas e que estava a receber-se com uma senhora; a morte talvez tivesse cortado esses laços. (COSTA, 1875 , p.XCI)

Continua ele ainda:

Ralado de saudades, condenado à morte como criminoso, pela pátria que tanto amara, pouco a pouco finou-se Saldanha de doenças que lhe produziram os excessos de bebidas alcoólicas a que se havia entregado, e nas quais procurara se entorpecer o sentimento que mais lhe dominava no espírito. (COSTA, p.XCI-XCII)

A versão de Argeu Guimarães é bem mais romanceada. Conta ele que o poeta em 
(...) certa noite, mais fria, mais silenciosa e mais triste, saiu do "Palomar" muito tarde para espairecer, não podendo conciliar o sono na áspera enxerga do leito de pedra. A escuridão compacta e as lufadas de ar gelado prenunciavam temporal. (...) O suor lhe pelava a fronte, apesar da temperatura glacial. (GUIMARÃES, 1932, p.197-8)

Em sua descrição, Guimarães relata-nos que Natividade Saldanha fora surpreendido por um cano, "imunda sarjeta, esgoto da cidade", que cortava uma das ruas em que transitava e, encontrando dificuldades para enxergar,

Dá um passo em falso. Perde o equilíbrio, escorrega, chafurda na sarjeta transmudada em caudal impetuoso. Debate-se como um náufrago, rodopia, dá com a cabeça no lajedo e morre... (GUIMARÃES, 1932, p.199)

Argeu Guimarães ainda complementa seu relato com as palavras de Ortiz:

(...) "não pôde safar a cabeça de dentro das águas, e afogou-se aí, num ribeiro insignificante, quem antes pudera livrar-se das ondas encapeladas do canal da Mancha". (GUIMARÃES, 1932, p.199)

Considerando o dramático fim de Natividade Saldanha, podemos concluir que Brito Broca não utilizou esses dois últimos estudiosos do poeta como referência, pois um detalhe tão surpreendente não escaparia a seu registro. 
Araújo Porto Alegre em Paris (1831)

Herança do Brasil colonial, a tradição do mecenato é lembrada na crônica "A formação de Araújo Porto Alegre”, enfeixada em Românticos, pré-românticos e ultraromânticos. Nela, Brito Broca nos conta que figuras como Gonçalves de Magalhães, Araújo Porto Alegre e Gonçalves Dias sempre "procuraram aproximar-se do Trono, depois de haverem superado grandes dificuldades econômicas no início da carreira literária e artística" (BROCA, 1979, p.59).

Segundo o cronista, logo após ter despertado o interesse de Dom Pedro I com o quadro histórico sobre a instalação da Academia de Medicina, Porto Alegre, além de tornar-se pintor da Imperial Câmara, obteve do monarca uma ajuda financeira para iniciar seus estudos artísticos na Europa. Entretanto, o pintor "não se pôde valer desse amparo" em razão de uma doença que lhe acometera no início de 1831, seguida da abdicação de Dom Pedro I, em abril do mesmo ano. Porto Alegre já havia se comprometido com o pintor francês Jean-Baptiste Debret a acompanhá-lo à Europa, mas passadas algumas dificuldades, consegue recursos para a viagem e permanência em Paris.

A crônica basicamente versará sobre os dissabores vividos por Araújo Porto Alegre em terras europeias. Entretanto, antes de seguir na trilha desse relato, é oportuna a compreensão de alguns fatos que o permeiam.

No livro $O$ pintor do romantismo, de Paranhos Antunes, obra de explícita referência para Broca, verifica-se muito da trajetória do artista até seu embarque para Europa.

\footnotetext{
"Chegou ao Rio de Janeiro, no dia 14 de janeiro de 1827, e achou hospitalidade em casa do senador Antônio Vieira da Soledade, devida esta a uma carta do seu amigo João Evangelista França, atual tesoureiro do Colégio Pedro II". (ANTUNES, 1943, p. 29)
}

Contando com o auxílio do senador (e também cônego) Soledade e do Visconde de São Leopoldo, ministro do Império a quem já conhecia do Rio Grande do Sul, Araújo Porto Alegre consegue se estabelecer na capital brasileira. No dia 27 de janeiro já se achava matriculado na recém-criada Academia Imperial de Belas Artes, tornando-se discípulo de Debret que, como relata Paranhos Antunes, "o recebeu com afago paternal". 
É importante ainda fazer uma pequena observação a respeito da citação acima, encontrada na obra de Paranhos Antunes. Este, como bem se depreende, busca as informações sobre Porto Alegre em uma autobiografia do pintor. Não obstante, se analisarmos a citação imprimida aqui, poderemos verificar que há um narrador exterior ao fato (“Chegou...”), ou seja, alguém que narra o acontecido sem nele estar, ao menos aparentemente, envolvido. Nossas suspeitas são confirmadas por Leticia Squeff em O Brasil nas letras de um pintor:

(...) não se trata de uma autobiografia comum: falta ao texto o primeiro elemento
que a define: o narrador que é ao mesmo tempo o sujeito da ação. Ou seja, ao narrar
sua história, Porto Alegre opera uma cisão entre aquele que comenta acontecimentos
e fatos e aquele que os vivenciou no passado, construindo toda a narrativa na terceira
pessoa. Por esse expediente, provoca no leitor a falsa sensação de que Porto Alegre e
o autor do texto não sejam a mesma pessoa. (SQUEFF, 2004, p.35-6).

Dessa forma, poderíamos considerar aquele recorte como parte do texto de Paranhos Antunes não fossem as aspas ali empregadas e a observação de Squeff, pois o emprego do verbo na terceira pessoa inevitavelmente nos remete à existência de um narrador heterodiegético.

Voltando a Paranhos Antunes, verificamos que a relação entre o jovem pintor e Debret estreita-se ainda mais com o passar dos anos. Araújo Porto Alegre destacou-se entre os alunos do mestre francês em razão de seu empenho nas aulas e também por uma querela tida com o diretor do estabelecimento, Henrique Silva, que proibira a permanência dos alunos após o horário estipulado. Ao que parece, o diretor da Academia havia feito várias retaliações às atividades de Debret, levando este a recorrer à Assembleia Geral para que fossem tomadas as providências cabíveis. A causa parece ganhar peso quando Porto Alegre escreve um artigo na Minerva brasiliense reclamando ao Imperador o direito de se estudar depois do horário de funcionamento. Assim, "Com essa primeira vitória, torna-se Araújo Porto Alegre o líder da turma, que exulta ante a derrota do diretor" (Ibidem, p.34).

A primeira exposição realizada pela Academia também é concretizada mediante ação de Araújo Porto Alegre. Conta Paranhos Antunes que, a contragosto do diretor, os alunos puderam expor seus trabalhos ao público em fins de 1929, recebendo Porto Alegre na ocasião três prêmios, nas áreas de pintura, arquitetura e escultura.

Retornando o senador Soledade ao Rio Grande do Sul, é na residência de Dom José Caetano, na ocasião bispo do Rio de Janeiro, que Porto Alegre irá hospedar-se. É interessante 
perceber que o artista aproveita sua estadia no Rio para tecer uma rede de relações, a qual lhe será de grande valia futuramente na Europa.

"No Palácio da Conceição teve a fortuna de ter por companheiros e amigos muitos jovens talentosos, entre os quais se notavam os muito respeitáveis e ilustres bispos do Maranhão e da Diamantina. O jovem artista teve sempre inclinação à sociedade dos homens velhos e talentosos, porque dele sempre lucrava. Entre as pessoas notáveis que o admitiam à companhia e privação, contam-se Evaristo Ferreira da Veiga, o Dr. Lino Coutinho, o grande orador Sampaio seu colega Monte Alverne, o senador Paula Souza, o Barão Inhomerim, Antonio Carlos, Martim Francisco e o imortal José Bonifácio, por quem tinha uma espécie de adoração, e outras mais notabilidades". (ANTUNES, 1943, p.38)

Nossas observações fazem coro à de Paranhos Antunes quando este nos diz em seu livro que:

É preciso atentar para a nobre sociedade com quem o moço convive no palácio episcopal. Mercê de Deus, ele tem a ventura de achar abrigo sob o teto de uma das mais acatadas figuras da Corte, que se torna assim o seu mecenas. E ali, naquele palácio, na intimidade dos grandes do Império, é tratado como amigo, como igual, recebendo lições de alta cultura e fina cortesia. Não é, portanto, para admirar que, pouco tempo depois, em Paris, saiba se impor, mova-se com desembaraço e não faça má figura ante as maiores cerebrações do mundo. (ANTUNES, 1943, p.38)

Araújo Porto Alegre, em 1830, é considerado o pintor da moda, como bem lembra Paranhos Antunes. Várias encomendas lhe são feitas e ele revela-se um "exímio retratista". É nesse momento que recebe a proposta para pintar um painel representando Dom Pedro I entregando o decreto da reforma da Academia de Medicina ao corpo acadêmico. Esta obra foi considerada umas das mais importantes na exposição de Belas Artes de 1830, "figurando o seu autor em primeiro lugar no catálogo publicado por Debret” (Ibidem, p.40). A originalidade das obras apresentadas pelo novo talento da pintura passa a ser, segundo Antunes, modelo para os outros colegas. Vemos, então, que

Domingos José Gonçalves de Magalhães, por exemplo, colega e amigo de Porto Alegre, que ali inicia uma amizade com o artista, que há de perdurar por toda a vida, expõe "cópias de diversos estudos feitas da natureza por Araújo Porto Alegre"; Antônio Pinheiro de Aguiar, também ali expõe "cópias de estudos feitos por Araújo Porto Alegre"; José Correia de Lima apresenta "o retrato de Moniz copiado de Araújo Porto Alegre"; Marcos José Pereira comparece com alguns trabalhos e "cópias de estudos de Araújo Porto Alegre"; e João Clímaco exibe "cópias dos estudos de Araújo". (ANTUNES, 1943, p.41)

Parece, portanto, não haver dúvida de que o discípulo de Debret havia conseguido apropriar-se dos ensinamentos "do amor da arte pela arte", tão incutidos pelo mestre. Mas é com a visita do Imperador à Academia de Belas Artes no momento em que ainda executava o 
trabalho de pintura do quadro da instalação da Academia de Medicina que Araújo Porto Alegre recebe um importante convite. Após verificar que sua fisionomia não havia sido reproduzida como desejava, ordenou o Imperador que o jovem o procurasse no Palácio da Quinta da Boa Vista “porque assim o veria melhor”. Dessa forma,

"No dia 12 de outubro foi ele e teve as audiências. No momento em que concluía o seu trabalho em presença da Família Imperial, chegou-se ao ouvido do Imperador a Imperatriz e este lhe respondeu:

- Não tem dúvida, há de ser servida, minha senhora.

"E voltando-se para o artista, disse-lhe:

- A Imperatriz quer este retrato porque o julga o mais perfeito de todos, e logo que o acabares lhe virás entregá-lo; depois me hás de fazer outro, e o dela e o de meus filhos, os quais irás tu mesmo levar à minha sogra a Princesa Augusta de Leuchtemberg, residente na Baviera, e de lá partirás para a Itália ou onde melhor te convier estudar, contanto que lá não fiques. (ANTUNES, 1843, p.45-6)

É neste ponto que tomamos nossa conexão com o texto de Brito Broca, pois a partir dela podemos acompanhar com mais proximidade sua leitura. Referindo-se ao último parágrafo da citação acima, diz o cronista que esse era o modo pelo qual o Imperador "se dirigia a qualquer lacaio" e que tal linguagem na época não era estranha a ninguém, pois outra não usavam "os soberanos quando estendiam o manto protetor por sobre os súditos mais modestos" (BROCA, 1979, p.59).

Coberto por tal "manto protetor", Araújo Porto Alegre tem diante de si abertas as portas que o levariam a "realizar o seu maior sonho, seguindo para a Itália, a fim de aperfeiçoar-se na pintura.” (ANTUNES, 1843, p.46) Porto Alegre ainda formaria, juntamente com os colegas Gonçalves de Magalhães e Torres Homem, uma roda literária - provável fruto dos encontros nos salões de Dom José Caetano e das reuniões na loja de Evaristo da Veiga, figura de destaque na política do período. (SQUEFF, 2004, p.66)

É interessante notar que em Teatro das letras, na crônica “As 'capelinhas' literárias", Brito Broca comenta algo a respeito desses pequenos grupos. Vejamos:

Ante os grupelhos que se multiplicam no Rio de Janeiro e em São Paulo, sob o rótulo cada vez mais abusivo de geração, tecendo os fios de uma tediosa política literária, tingida por vezes de mundanismo, somos levados a atenuar até certo ponto a nossa repulsa, lembrando-nos de que essas "capelinhas" foram sempre uma constante da vida intelectual em todos os tempos e em todos os países. (BROCA, 1993, p.11)

Nesse artigo Broca faz um pequeno balanço do surgimento de grupos que, como o de Porto Alegre, reuniam-se para exercer a atividade de autoapreciação de suas obras. Segundo o 
cronista, “As 'academias' dos tempos coloniais ainda não tinham o caráter de 'capelas', pois nelas não prevalecia o elogio mútuo, mas o elogio comum ao rei, aos mecenas e aos poderosos" (Ibidem, p.12). Afirma ainda que "o objetivo dos escritores era, então, bajular os que podiam pensioná-los e dar-lhes o amparo material de que necessitavam para produzir”. Brito Broca lembra que

Com o Romantismo é que surgem verdadeiramente as primeiras "capelas" entre nós. Gonçalves de Magalhães, Porto Alegre, Torres Homem formaram um "grupinho" bem característico de elogio mútuo. Basta ver os louvores excessivos e quase ridículos que trocaram, principalmente os dois primeiros. (BROCA, 1993, p.12)

Continua ainda, um pouco adiante:

Podemos dizer, no entanto, que o chefe dessa "panelinha" era o próprio Imperador, que no seu longo reinado, com um interesse maníaco pelas Letras, sempre foi um homem de "capelas" literárias. (BROCA, 1993, p.12)

Inserido, portanto, no "grupelho" formado pelo Imperador, a ideia de uma viagem à Europa soaria como algo natural na vida de Porto Alegre. Brito Broca começa, então, dizendo:

\begin{abstract}
Uma doença quase no início do ano de 1831 e a abdicação de Dom Pedro I em abril puseram tudo por terra. Mas o pintor já se havia comprometido antes com seu mestre, Jean-Baptiste Debret, de acompanhá-lo à Europa. No entanto, o dinheiro que reservava para isso, cinco mil cruzados, emprestara-os a um primo, amigo de infância, não conseguindo reavê-lo. O devedor partira estradeiramente para o Rio Grande do Sul, esquivando-se do pagamento. (BROCA, 1979, p.59-60)
\end{abstract}

Qual teria sido a doença, ou mesmo a sua gravidade, não conseguimos apurar em Brito Broca e nem com Paranhos Antunes. O dinheiro havia-o recebido por conta de sua emancipação. O curioso, revela este último, é que Porto Alegre somente toma conhecimento do calote ao ler no Jornal do Commercio uma nota sobre a partida do primo para o Rio Grande do Sul. É aqui, no entanto, que sua teia de relacionamentos começará a agir:

Desesperado (...) escreve à mãe, ao primo relapso e ao Cônego Soledade, todos lá no Rio Grande do Sul. Só deste último consegue obter uma ordem de cem mil-réis fortes a lhe serem pagos mensalmente na França. Estava garantida uma pequena mesada. Só faltava a passagem. Vêm-lhe em auxílio José Bonifácio e Evaristo da Veiga; o primeiro dando-lhe uma carta para o Almirante Grivel, que lhe valeria uma passagem grátis a bordo do navio de guerra francês Durance; o segundo obtendo-lhe, por subscrição, a quantia de 400 mil-réis fortes, como ajuda de custo para essa empresa que implicava sem dúvida, certo espírito de aventura. (BROCA, 1979, p.60) 
A crônica parece ganhar fôlego quando Porto Alegre desembarca na França e Broca passa a perseguir seus passos. O curioso é que o cronista não menciona, por exemplo, que Porto Alegre, ao chegar a Paris, matriculou-se na escola do Barão de Gros; que, por influência de Debret, foi recebido no Institut de France, juntamente com Domingos de Magalhães e Torres Homem, onde pronunciou um discurso traçando uma síntese histórica das belas artes no Brasil, publicado, segundo Antunes, em vários jornais de Paris, como Le Moniteur Universelle; tampouco cita que, frequentando também a casa de François Debret, Porto Alegre passou a ter contato com músicos como Rossini, Auber, Boieldieu, Cherubini e Päer, sem falar "nas plêiades de pintores, escultores e outros homens de primeira plana" (ANTUNES, 1843, p.59). O pintor teria tido ainda grande proximidade com o romântico português Garrett, exilado na França por defender seus ideais liberais; e outro músico, Sigismund Neukomm, que lhe contou sobre sua experiência no Brasil com a missão de Lebreton, em 1816. De qualquer maneira, não nos causaria reparo tal omissão não fosse o título da crônica se referir justamente à formação de Porto Alegre, e se esses encontros também não tivessem contribuído para o crescimento do pintor, visto que a atmosfera que se respirava na ocasião iria influenciar um dos que seria o fundador do Romantismo no Brasil.

O que também não nos conta Broca é que Porto Alegre desembarcara em uma França que ainda irradiava a grande agitação política e literária vivida há pouco: a Revolução de julho de 1830, que pôs fim ao reinado de Charles X, e a publicação do prefácio de Cromwell, de Victor Hugo, que punha por terra o "classicismo e suas velhas formas teatrais" (BERRETTINI, 2002, p.9). Parece mesmo que o cronista busca outro rumo para sua investigação. Mas qual seria?

Vamos encontrar um pouco da atmosfera vivida por Porto Alegre em carta de seu amigo, Gonçalves de Magalhães, a Monte Alverne, pregador oficial do Império, em que aquele dizia:

Os poetas estão aqui empenhados em explorar a mina da meia-idade, fatigados com as ideias antigas, e não podendo quase marchar na estrada de Racine e Corneille e Voltaire, eles calcam todas as leis da unidade tão recomendadas pelos antigos; as novas tragédias não têm lugar fixo, nem tempo marcado, podem durar um ano e mais; o caráter dessas composições é muitas vezes horrível, pavoroso, feroz, melancólico, frenético e religioso. Os assassínios, os envenenamentos, os incestos são prodigalizados às mãos largas, mas nem por isso deixam de ter pedaços sublimes. Os principais trágicos são De Laragotine, Alexandre Dumas, Victor Hugo. Esses poetas chamam-se românticos; eu tenho visto representar as principais dessas peças. (LOPES, 1962, p.16-17) 
Paranhos Antunes, por sua vez, faz ao menos uma observação sobre o contexto em que se insere o pintor brasileiro:

\begin{abstract}
Em chegando a Paris, escuta ainda os ecos da luta travada naquela noite histórica $^{20}$, e toma parte na batalha em plena efervescência, pois que os clássicos estão encastelados em jornais e revistas prestigiosos, de onde queimam com vigor os últimos cartuchos. (ANTUNES, 1843, p.52)
\end{abstract}

Broca, não obstante, prossegue contando-nos que se inicia para Porto Alegre um período de grandes dificuldades financeiras. Segundo ele, após perder o auxílio que recebia de alguns amigos brasileiros, o pintor teria passado por uma "grave enfermidade, que acabou de arrasá-lo financeiramente (...)" (BROCA, 1979, p.60) e por isso teve que vender seus livros, um relógio, um alfinete de peito e "até a melhor roupa" (Ibidem). O cronista afirma ainda que para não morrer de fome Porto Alegre viu-se obrigado a pintar tabuletas e retratos de ocasião. Além disso, passou a contar com "algum auxílio do mestre Debret (...) e da generosidade do patrício e depois amigo Dr. João Martins Leão, que por mais de uma vez lhe franqueou a mesa".

Desse modo, pode-se concluir que Brito Broca aparenta estar muito mais interessado em rastrear os apuros financeiros vividos pelo pintor do que propriamente com os aspectos que dizem respeito à sua formação profissional. Evidentemente, não negamos aqui que este tipo de experiência contribua para o amadurecimento de qualquer ser humano, entretanto, basear-se somente neste fator é correr o risco de adotar uma visão unilateral dos acontecimentos da vida de uma pessoa. Tal fato causa reparo, sobretudo se lembrarmos que é o próprio cronista que vai, muitas vezes, questionar a falta de interesse de escritores e artistas brasileiros em relacionar-se (e, principalmente, relatar suas experiências) com escritores ou artistas franceses estando uma vez na França.

O pintor, continua Broca, teria se encontrado com Dom Pedro I no Boulevard des Capucines, sendo que este também "não tinha emprego para oferecer-lhe, mas podia deixarlhe alguns bilhetes de banco na mão (...)" (Ibidem). Ao que parece, Porto Alegre não acrescenta mais nada a este assunto e Brito Broca prossegue, relatando-nos que no momento

\footnotetext{
${ }^{20}$ Em 25 de fevereiro de 1830, noite de estreia da peça Hernani de Victor Hugo, favoráveis à tragédia clássica e defensores do drama romântico travaram verdadeira batalha dentro da sala de espetáculo. Seguindo a linha adotada por Cromwell e seu prefácio, o escritor fez uso de uma nova estrutura (abertura do espaço e do tempo), rompendo, dessa maneira, com a regra das três unidades proposta por Boileau.
} 
em que o pintor já pensava em retornar ao Brasil, recebe um auxílio de vinte mil francos (dos quais aceita apenas quatro mil e não dez, como está registrado na crônica) de Luís Meneses de Vasconcelos Drummond $^{21}$ que havia acabado de chegar a Paris. A quantia era suficiente para que Porto Alegre seguisse para a Itália, pois sua hospedagem estava garantida na residência do Conselheiro Rocha e seu filho. Antes, porém, de partir, escreve ao amigo e protetor Evaristo Ferreira da Veiga carta em que partilha sua indecisão entre retornar ao Brasil e seguir seus estudos em Roma. Dela, destacamos a desilusão com Paris e o afloramento de ideais românticos:

“(...) Paris já não tem atrativos para mim, quem gosta de vadiação tem nele seu alento; teatro, danças, etc. é para quem tem dinheiro e gosta, portanto, eu já não posso aqui viver, demais a idade avança, o tempo foge e a minha Pátria e família me chamam; agora o meu único desejo é ter discípulos, vê-los mais fortes do que eu". (ANTUNES, 1843, p.66)

Dessa forma, verificamos que, por trás do grande desejo de retornar ao Brasil, existe também certo espírito romântico em suas linhas. O tema da construção da identidade nacional, tão cantado pelos românticos, parece subjazer ao discurso de Porto Alegre quando este afirma ao colega que seu "único desejo é ter discípulos". Nossas suspeitas são confirmadas pelas palavras de Paranhos Antunes:

Como pintor, os quadros que nos deixou são tocados pelo romantismo muito de leve, mas como professor e escritor viveu aconselhando aos discípulos e leitores que se votassem ao estudo das cousas da pátria e que deixassem de pensar como europeus. Como poeta, ele foi, mais do que ninguém, o pintor do romantismo. (ANTUNES, 1843, p.71)

Nosso cronista, por sua vez, prossegue sua investigação sobre os recursos de que se valiam os brasileiros na Europa, não se restringindo apenas a Porto Alegre. Ocupou-se também em seu texto do amigo, Gonçalves de Magalhães. Segundo ele, Magalhães sobrevivera em Paris não se sabe com que recursos. Afirma que em Le Brésil Littéraire, Ferdinand Wold "estendendo-se sobre as conjunturas econômicas de Porto Alegre, não esclarece esse aspecto da vida de Magalhães”. Não obstante, na obra de Paranhos Antunes o cronista consegue encontrar o registro de que Gonçalves de Magalhães, em Paris, teria passado pela mesma situação de Porto Alegre. Dessa forma, a amizade desses dois brasileiros

\footnotetext{
${ }^{21}$ Antes da ajuda de Luís de Meneses, na sessão de Câmara de 1834, os adversários políticos Martim Francisco de Andrada e Evaristo Ferreira da Veiga uniram forças para propor uma pensão ao pintor que, em razão de algumas desavenças políticas, foi refutada pelo ministro Aureliano Coutinho.
} 
fazia "com que se amparassem mutuamente, ante as mesmas dificuldades" (BROCA, 1979, p.61).

Ainda na esteira de Paranhos Antunes, Broca nos conta que Gonçalves de Magalhães seguiu junto com o pintor para a Itália, pois "estaria nessa ocasião, além de doente, sem pensão, num estado verdadeiramente desesperador". Dessa forma, "não fora esse amparo talvez não viesse a escrever as obras com as quais se tornaria a principal figura do nosso Préromantismo" (Ibidem). Entretanto, após quatro meses, Magalhães é nomeado adido da Legação Brasileira de Paris, graças ao Conselheiro Rocha, e retorna à capital francesa. Porto Alegre permanecerá por mais algum tempo na Itália, porém, "Não tardará também a regressar à França, à míngua de recursos”, passando novamente ao convívio do amigo, bem como o de Torres Homem, que exercia na ocasião o mesmo cargo que o poeta. Com este último, os outros dois fundaram a revista Niterói, "em que se ensaiaram os primeiros movimentos do nosso Romantismo" (Broca, 1979, p.62). A revista, segundo nos afirma Broca, não teve mais do que dois números, pois Magalhães e Torres Homem, não tolerando mais as "impertinências" do Conselheiro Moutinho, pediram demissão do cargo e ficaram sem meios para prosseguir com o periódico.

Quando retorna à França, Porto Alegre, conta Broca, consegue se restabelecer financeiramente graças a uma pensão oferecida por Martim Francisco, chegando até mesmo a realizar algumas viagens para países como Holanda, Bélgica e Londres, sempre acompanhado do amigo inseparável. No entanto, no que diz respeito às relações culturais entre brasileiros e franceses, Broca oculta novamente outro fato que talvez fosse importante ser abordado aqui.

Mais uma vez, bebendo da própria fonte de nosso cronista, é em Paranhos Antunes que somos informados de que Porto Alegre, logo que regressou da Itália, fora convidado por José Michaud, presidente do Instituto Histórico de Paris, "para ler, no Congresso Europeu, uma memória $^{22}$ em que se comparasse a arte antiga com a moderna" (ANTUNES, 1843, p.81). Esse mesmo senhor também o nomeou para a comissão da exposição geral do Louvre em 1836, cujo relatório final, "um monumento de erudição e senso estético" em que o pintor tece algumas considerações sobre o romantismo, chegou a ser parcialmente reproduzido em

\footnotetext{
${ }^{22}$ Araújo Porto Alegre não chegou a realizar tal trabalho em virtude de uma forte febre que o acometeu na época.
} 
um texto de Alexandre Lenoir ${ }^{23}$. Vejamos os trechos do texto de Porto Alegre incorporados ao discurso de Lenoir:

"L’empire n'était que le résultat de la révolution, et l'art a pris quelque essor; la pensée publique n'était préoccupée que d'un seul homme; elle resumait en lui tous les destins de l'humanité, et l'art a essayé de quitter la Grèce et Rome pour reproduire la gloire nationale; il a attaché son char à celui du triomphateur.

La restauration était à l'empire ce que la révolution avait été à l'ancien régime; une idée nouvelle devait éclore pour fermer la marche de celle qui était en possession du terrain. Il n'était pas possible de rétrograder jusqu'aux dieux de la Grèce et de Rome. L'histoire moderne n'avait encore rien à dire; une époque restait vierge, et le moyen-âge fut ressuscité. La restauration était arrivée escortée des idées religieuses, mais ces idées n'avaient pas encore jeté de profondes racines dans les masses. L'art ouvre la Bible, y cherche des sujets analogues aux idées du moment, mais l'inspiratoin lui manque. A peu d'exception près, on chercherait en vain dans les productions de ce temps de l'empreinte de ce type religieux qu'on admire dans les ouvrages de Giotto, de Masaccio et de Raphael, et qui nous transporte vers au ciel". (ANTUNES, 1843, p.82-3)

O que chama a atenção aqui, como bem lembra Paranhos Antunes, é o modo severo como o pintor critica o romantismo, alegando faltar a seus adeptos inspiração e que "estão muito longe de poder igualar a Giotto, Masaccio e Rafael”. Entretanto, como lembra o próprio Antunes, é importante observar que "o romantismo recém ensaia os seus primeiros remígios em arte e que Porto Alegre, já é, sem o querer talvez um pintor da nova escola (...)" (ANTUNES, 1843, p.83).

Brito Broca, por sua vez, não se detendo a este fato, parte para a conclusão da crônica, buscando novamente apresentar ao seu leitor a situação econômica dos brasileiros na Europa. Assim, encerra ele dizendo:

(...) Tudo indica ainda ter sido Porto Alegre quem custeou a publicação do livro do amigo Suspiros poéticos e saudades, considerado o primeiro rebento do nosso Romantismo e impresso em Paris em 1836. (Broca, 1979, p.62)

Para nós, o que se faz claro é a distância das rotas tomadas por Broca e Antunes. A comparação é inevitável e, mais uma vez, pode-se confirmar a maior profundidade deste último no tratamento do tema em razão do suporte de que se vale, ou seja, o livro. Não obstante, o que também claramente se manifesta na crônica de Brito Broca é a sua insistência em tratar das finanças do pintor brasileiro enquanto esteve na Europa.

\footnotetext{
23 Arqueólogo fundador do Museu dos Monumentos Franceses. Também conhecido por suas diversas obras sobre arte.
} 
Como já comentado, esse viés adotado por ele pode, à primeira vista, pode trazer algumas limitações ao texto, pois, afinal, propor-se a contar a história da formação profissional de uma figura como Porto Alegre valendo-se somente de suas dificuldades econômicas implica deixar de lado uma série de outros fatores que sem dúvida seriam relevantes para a totalidade da empreitada, como muitas vezes apontados aqui. Mas há, na apreensão dos fatos - literários ou não - a escolha. E tal atitude passará sempre pelo crivo pessoal, restando, portanto, aquilo que saltar aos olhos do crítico.

Posto isso, quando analisamos a escolha de Brito Broca, podemos até considerá-la pouco usual ou evasiva, porém não podemos negar-lhe a sua eficiência. Retratar em uma crônica o processo vivido por um profissional em formação apoiando-se quase que exclusivamente nas suas desventuras financeiras é, sem dúvida, levar o leitor diretamente ao cerne da questão. Dizemos isso porque sabemos que a questão financeira influencia, muitas vezes, de forma direta uma boa formação profissional. Ademais, nada mais romântico do que relatar as dificuldades financeiras vividas (com seus altos e baixos) por um daqueles que mais tarde seria um dos grandes representantes do Romantismo no Brasil, ainda que na pintura. 
Nísia Floresta na Europa (1849)

Em crônica de 1953, intitulada "As mulheres na Literatura Brasileira", Brito Broca tem como objetivo traçar um pequeno panorama da atuação das primeiras mulheres do país como escritoras. Esse artigo, recolhido em Românticos, pré-românticos e ultra-românticos, toma como base a obra Precursoras Brasileiras, de Barros Vidal, como indicado pelo próprio cronista. O destaque dado ao nome de Nísia Floresta se deve em razão do fato da brasileira ter estabelecido residência na França e também pelo fato de ter se relacionado com alguns importantes escritores e pensadores franceses da metade do século XIX, como Lamartine, Victor Hugo e Auguste Comte, dentre outros.

Se a falta das fontes utilizadas é algo que sempre causa reparo em muitas das crônicas de Broca, dessa especificamente não lhe podemos cobrar muito. A obra de Barros Vidal ${ }^{24}$ é a grande referência do cronista, sobretudo quando fala das pioneiras no ofício de escrever.

Tentando estabelecer uma ordem cronológica, Brito Broca inicia sua leitura lembrando o nome de Teresa Margarida da Silva Orta (1711 - 1793), autora de Aventuras de Diófanes, obra de 1752. Afirma que até o fim do século XIX, "a literatura no Brasil continuava a ser tida como uma atividade pouco adequada ao sexo feminino" (BROCA, 1979, p.76). Relembra ainda o fato de que ser escritor ou poeta, até mesmo para os homens, trazia sempre "qualquer coisa de anti-social e, principalmente, de antiburguês". E fala da luta de nossas primeiras escritoras:

Foi um combate lento e persistente, correndo parelha com as reivindicações femininas noutros setores. O livro de Teresa Margarida é dos meados do século dezoito. Trata-se, no entanto, de uma mulher que, tendo nascido em São Paulo, foi com a idade de cinco anos para Portugal, lá estudou e lá escreveu a obra, que publicou sob pseudônimo. (BROCA, 1979, p.76)

\footnotetext{
${ }^{24}$ Em Precursoras Brasileiras (ver referências bibliográficas), a pesquisa de Barros Vidal traz o nome de várias mulheres que se destacaram como pioneiras em vários campos de atuação tidos até o momento como de domínio masculino. Seus capítulos, portanto, recebem nomes do tipo "A primeira peregrina"; "A primeira guerreira"; "A precursora do romance brasileiro", referindo-se nesse caso a Teresa Margarida da Silva e Orta; "Qual a primeira poetisa?", em que destaca os nomes de Rita Joana de Sousa e Ângela do Amaral Rangel; "A precursora do feminismo", para tratar de Nísia Floresta; etc. Em sua crônica, Brito Broca considera somente aquelas que se dedicaram a escrever.
} 
"Dorothea Engrassia Tavareda Dalmira". Este era o pseudônimo usado por Teresa Orta, segundo o fac-símile contido em Precursoras Brasileiras. O cronista atribui muito o surgimento do livro da escritora à possibilidade que ela teve de poder estudar em Portugal, pois, considera, caso permanecesse na Colônia, "certamente nunca viria a compor coisa alguma; nem chegaria a adquirir instrução necessária para qualquer espécie de exercício literário" (Ibidem).

Em Barros Vidal, vemos a existência de duas polêmicas em torno do romance de Orta. A primeira delas se refere a quem teria sido de fato o primeiro romancista brasileiro. E Vidal nos explica:

\begin{abstract}
No esquema da história da nossa literatura aparecia Pereira da Silva como o primeiro romancista brasileiro, com a sua obra "Jerônimo na Côrte Real", publicada em 1839, no gênero fantasia histórica, e Teixeira e Sousa em 1843 com o "Filho do pescador", verdadeira ficção, e Joaquim Manuel de Macedo, em 1844, com a "Moreninha", que se ilumina de todos os característicos de um verdadeiro romance popular, pois até hoje, um século depois, é lido com entusiasmo por muita gente. Mas os documentos históricos rebuscados nos arquivos de Portugal por Ernesto Enes provam, de maneira definitiva, que o primeiro romance escrito por brasileiro apareceu em 1752. (VIDAL, [194-?], p.22-3)
\end{abstract}

Não é, como explica Vidal, nenhuma coincidência. Trata-se da obra de Teresa Orta. Entretanto, eis a segunda polêmica. A obra Aventuras de Diófanes teve sua autoria atribuída a outro escritor, ou melhor, o nome de dois possíveis autores concorreram como produtores do livro. São eles: Alexandre de Gusmão ${ }^{25}$ e Nuno Marques Pereira ${ }^{26}$, justamente estes que, como lembra Vidal, haviam publicado dois livros totalmente "despidos dos característicos marcantes do romance, tão claro o seu espírito de propaganda religiosa” (Ibidem).

Como o romance era assinado por Doroteia Engrassia Tavareda Dalmira, o debate só foi encerrado mediante intervenção do abade Barbosa Machado, o qual

(...) no tomo IV de sua "Biblioteca Lusitana", publicado em 1759, diz que foi ela mesma [Orta] quem escreveu "Máximas de virtude e formosura", cuja segunda edição, publicada em 1777, traz um título mais sintético: "Aventuras de Diófanes", embora sem a dedicatória que figurava na anterior, à D. Maria I. (VIDAL, [194?], p. 23)

\footnotetext{
${ }^{25}$ Pedro Alexandre de Gusmão (1629 - 1725) foi um padre jesuíta e escritor lisboeta que veio para o Brasil em 1644 e fundou na Bahia o Seminário de Belém, do qual foi reitor. Escreveu Predestinado peregrino.

${ }^{26}$ Nuno Marques Pereira (1652 - 1728) também foi padre e escritor. É autor de O peregrino da América.
} 
Fica, portanto, esclarecido que Aventuras de Diófanes tratava-se da segunda edição de Máximas de virtude e formosura, tornando claro que a obra de Teresa Orta teria sido o primeiro romance de autoria genuinamente brasileira.

A cronologia empregada nesse artigo nem sempre segue sua devida ordem. No capítulo “Qual a primeira poetisa brasileira?", Brito Broca revela a seus leitores as primeiras brasileiras a fazerem versos no país, remontando ao final do século XVII. Como lhe informa Vidal,

(...) em 1696 já era possível encontrar no Brasil uma mulher fazendo versos, a pernambucana Rita Joana de Sousa, que teria sido a nossa primeira poetisa. Onde foram parar tais versos? Como não havia imprensa na Colônia, é de presumir-se não chegassem a ser publicados. (VIDAL, [194-?], p.77)

Como se percebe, o cronista volta alguns anos no tempo para informar seu público da primeira poetisa nascida no Brasil. O nome de Rita Joana de Sousa (1696 - 1718) surgiu das pesquisas de Vidal para encontrar a pintora que Sousa também fora; porém, acabou encontrando dados que a caracterizavam como grande poetisa. O comentário de Brito Broca a respeito de onde teriam ido parar tais versos é, na verdade, fruto da leitura de Vidal no momento em que este, por sua vez, cita em sua obra um trecho do Ano Biográfico Brasileiro, de Joaquim Manoel de Macedo, de 1876. Neste livro, Macedo se queixa da falta de uma imprensa capaz de veicular o trabalho da poetisa.

Durante muito tempo, afirma Broca, a poesia teve "função de ornamento social no Brasil". O cronista acredita, portanto, que, seguindo os costumes da época, "Rita Joana de Sousa limitar-se-ia, talvez, a recitar suas poesias de sentido laudatório nos jantares de aniversario e casamento, nas festas em homenagem aos grandes da terra" (BROCA, 1979, p.77). Depreende-se, portanto, que a poetisa teria difundido seu trabalho por meio dessas convenções, ignorando, talvez de maneira involutária, o meio impresso de divulgação.

Outra poetisa tratada como umas das primeiras a escrever no Brasil é Ângela do Amaral Rangel. Broca nos dá o seguinte relato da escritora:

Já no Século 18, Ângela do Amaral Rangel, nascida no Rio de Janeiro, em 1725, deixou alguns versos impressos. Era cega, e entre as produções mais conhecidas de sua lavra figura a que declamou na Academia dos Seletos, na festa ali realizada em honra a Gomes de Freire de Andrade, em 1752. (BROCA, 1979, p.77) 
O trecho acima revela, quando comparado à sua fonte, a síntese do cronista. Em Vidal, essas informações podem ser confirmadas, incluindo aí o fato da poetisa também não ter deixado impresso um só livro e ser conhecida como a "Ceguinha".

Na sequência, o cronista fala do Jornal das Senhoras, fundado em 1852, no Rio de Janeiro, por Joana Paula Manso de Noronha ${ }^{27}$ (1819 - 1875). O periódico, conta ele, "tratava, além de literatura e arte, de modas e mundanidades, representando, assim mesmo, uma grande conquista para a época" (Ibidem). Brito Broca colhe essas informações no capítulo "A primeira jornalista", em Precursoras Brasileiras. O cronista afirma que o "periódico lutou com grandes dificuldades", pois não faltou quem "hostilizasse o empreendimento dessas femmes savantes". A folha durou quatro anos.

A baiana Violante Atabalipa Ximenes de Bivar e Velasco (1817 - 1875) foi colaboradora desse periódico. Vidal comenta que sua atuação foi impressionante porque representava "a luta de uma vocação contra uma época". Violante de Bivar também desenvolveu atividades de tradutora, chegando a verter para o português obras de Alexandre Dumas, Eugenie Sue e outros.

Do capítulo "A precursora do feminismo: Nísia Floresta", Brito Broca retira os elementos para relatar um pouco da história dessa mulher que teve a ousadia como um traço característico de sua personalidade. É o que se depreende do parágrafo dedicado a ela em que o cronista nos conta que Nísia Floresta "escandalizava o conservadorismo da burguesia monárquica, com suas conferências públicas na Corte, preconizando a emancipação da mulher e defendendo ideias revolucionárias" (BROCA, 1979, p.77).

O cronista relata ainda que a atitude da escritora gerou tanta polêmica "que consta terlhe sido aconselhada uma viagem à Europa, para atender ao desejo dos que se inquietavam com as suas atividades" (Ibidem). Entretanto, em Barros Vidal confirma-se que Nísia também partira para lá em razão dos problemas de saúde de sua filha. Em um estudo cronológico da vida e da obra de Nísia Floresta, Constância Lima Duarte ${ }^{28}$ confirma os dois motivos que

\footnotetext{
${ }^{27} \mathrm{Na}$ crônica de Brito Broca parece haver um engano em relação ao nome da fundadora do jornal. Nela, lê-se "Joaquina" vez em de Joana.

${ }^{28}$ Esse estudo encontra-se no livro Itinerário de uma viagem à Alemanha, cuja tradução é de Francisco das Chagas Pereira. (ver referências bibliográficas)
} 
impulsionaram a escritora a seguir para a Europa. A viagem, segundo Duarte, ocorreu no ano de 1849.

No dia 7 de setembro, Lívia sofre um acidente ao cair de um cavalo e o médico, após semanas de tratamento, aconselha mudança de ares. Nísia Floresta resolve, então, ir para a Europa com os dois filhos, o que faz em 2 de novembro a bordo da galera francesa Ville de Paris. Para muitos, a saúde da filha foi apenas o pretexto para ela se ausentar do país. Com efeito, a campanha difamatória nos jornais e o sucesso do livro elogiando os liberais eram motivos suficientes a escritora se sentir pouco à vontade na Corte. (DUARTE, 1998, p.23)

Ao chegar à França, comenta Duarte, Nísia presencia o "conturbado clima parisiense, ainda não de todo refeito das revoluções do ano anterior" (Ibidem). A permanência na Europa rende à brasileira algumas amizades ilustres, como a estabelecida com Auguste Comte, no momento em que passou a frequentar as conferências ministradas pelo filósofo em seu Curso de História Geral da Humanidade, no auditório do Palais Cardinal. Quando resolve excursionar pela Europa, em julho de 1851, Nísia Floresta "vai ao Chateau de Madri, no Bosque de Bolonha, despedir de um amigo ilustre". Em 1852, retornaria ao Brasil, fato que é registrado pelo Jornal das Senhoras.

Aqui, Nísia publica Opúsculo Humanitário e vários artigos em jornais cariocas. Sua atuação como defensora dos direitos femininos prossegue até 1856, ano que retorna à França e passa a conviver com os amigos intelectuais, sobretudo Comte. Data desse período a correspondência trocada com o filósofo que morreria no ano seguinte. A brasileira é uma das poucas que acompanha o cortejo do amigo.

Em 5 de setembro morre Auguste Comte após semanas de agonia. Nísia Floresta é uma das quatro mulheres que acompanha o cortejo fúnebre até o Père Lachaise, junto de Sophie Bilaux, a filha adotiva de Comte, a irmã mais velha de Sophie, Mme Laveyssière e Mme Maria Robinet. (DUARTE, 1998, p.26)

O retorno à Europa é produtivo para Nísia, pois chega a publicar alguns livros em francês, dentre eles: Itinéraire d'un Voyage en Allemagne (1857); Conseils à ma Fille (1859), Trois ans en Italie, suivis d'un voyage en Grèce (1864); Le Brésil (1871); e Fragments d'un Ouvrage Inédit - Notes Biographiques (1878). A escritora volta ainda mais uma vez ao Brasil, em 1872, depois de dezesseis anos fora, mas logo regressa, no ano de 1875. Dirige-se primeiramente à Inglaterra para ver a filha, depois a Portugal e finalmente à França, Rouen, onde falece em 1885, vitimada por uma pneumonia. 
Nessa crônica é possível notar que Brito Broca impõe um ritmo muito mais acelerado do que normalmente costumamos ver. Capta somente aquilo que lhe parece ser o essencial das informações a respeito de Nísia Floresta, como se buscasse mostrar verdadeiramente os traços gerais da escritora. Mostra, em determinados momentos, certa ansiedade em resumir tudo, como nesse período: "Partiu ela para o Velho Mundo e lá se relacionou com Lamartine, Victor Hugo, Auguste Comte, vindo a escrever livros em francês e falecendo em Rouão" (BROCA, 1979, p.77). Talvez pela falta de espaço, o cronista tampouco chega a tocar na relevância da aproximação de Nísia Floresta e Auguste Comte, contato que provavelmente influenciou a vida da escritora.

Vale ressaltar ainda que a amizade de Nísia com Auguste Comte, o fundador do Positivismo, foi, em certa medida, importante para a divulgação de suas ideias entre os brasileiros. Alfredo Bosi afirma que a "militância positivista se fez sentir entre nós mais intensamente a partir do último quartel do século XIX”. Segundo ele, um levantamento feito por Teixeira Mendes, em 1924, mostra que, "entre 1850 e meados dos anos de 1870, a presença da doutrina limitou-se a expressões acadêmicas avulsas”. De acordo com Bosi, essa presença produziu um saldo positivo na história do país ao se considerar "o conformismo social de nossas oligarquias liberais desde o fim do Império até o ocaso da República Velha”. Para ele, o saldo positivo seria:

(...) o pensamento antropológico anti-racista; a precoce adesão à campanha
abolicionista mais radical; a luta pelo Estado republicano leigo com a consequente
instituição do casamento civil, do registro civil obrigatório e da laicização dos
cemitérios; a exigência sempre reiterada da austeridade financeira no trato da coisa
pública; enfim, o interesse pela humanização das condições de trabalho operário,
que resultou, tanto na França da Terceira República como no Brasil, em propostas
de leis trabalhistas, afinal implementadas quando políticos gaúchos de formação
positivista ascenderam ao poder central em 1930. (BOSI, 2004, p.22)

O motivo, no entanto, que leva Brito Broca a escrever sobre Nísia Floresta é sua condição de escritora e precursora do movimento feminista no Brasil. Dessa forma, não há como cobrar-lhe qualquer menção à influência de Auguste Comte na obra de Nísia, muito embora a filosofia positivista se propagasse por longo período no Brasil, como lembra Alfredo Bosi.

Terminado o tema "Nísia Floresta", Brito Broca parte para Narcisa Amália, poetisa que "pregava a Abolição em versos condoreiros, à maneira de Castro Alves"; e depois segue para a também poetisa Beatriz Francisca de Assis Brandão, à qual Joaquim Norberto havia 
proposto sociedade honorífica do Instituto Histórico e Geográfico, em 1850. O cronista relata ainda um episódio ocorrido em 1870, no Liceu de Artes e Ofícios, quando o poeta Luís Guimarães leu um artigo, "concitando as mulheres a vencer o preconceito que as afastava das letras".

A partir de Narcisa Amália e de Beatriz Francisca de Assis Brandão, podemos constatar que a fonte do cronista passa a ser outra. Percorrendo as páginas de Precursoras Brasileiras, não se encontra nenhum registro dessas poetisas. O cronista parte, então, para suas considerações finais, comentando:

Mas só com o advento do Naturalismo e do espírito cientificista que o informava, o movimento de emancipação intelectual da mulher tomou grande impulso no Brasil. (...) Com a extinção do Romantismo, a mulher perde a aura de deusa irreal, que a sufocava intelectual e socialmente, para ser vista como um ente humano, capaz de caminhar ombro a ombro com o homem, na luta pela vida. (BROCA, 1979, p.78)

A conclusão vem reforçar a ideia de que as mulheres puderam ter a oportunidade de expor seus pensamentos à sociedade somente muito tempo depois do surgimento de nossa literatura. Dessa forma, acreditamos que o texto de Brito Broca é bastante significativo quando se observa seu caráter de vulgarizador de mulheres escritoras como essas que davam os primeiros passos na luta pela igualdade de direitos com os homens. Nesse sentido, faz-se justo também indicar o nome de Barros Vidal e seu esforço por registrar o nome de todas que se aventuraram à condição de pioneira dentro de assuntos tidos como de ordem masculina. 
Nogueira da Gama na Europa (1855)

Comecemos, antes da apresentação dessa crônica, por ouvir as queixas de Brito Broca a respeito de brasileiros que estiveram na Europa do século XIX, mas que disso não deixaram nada relatado:

São escassos - temos dito e repetido - os testemunhos de escritores brasileiros sobre a Europa no século passado. Hoje, em que a Europa é tão conhecida, a maioria dos intelectuais que a visitam não se esquiva de escrever suas impressões, senão em livro, pelo menos em artigos; entretanto, só no período romântico, isto é, de 1830 a 1870, quantos escritores brasileiros por lá andaram ou mesmo residiram sem cogitar disso. (BROCA, 1979, p.203)

A escassez de registros apontada pelo cronista lhe servirá aqui como justificativa para lançar mão de outros nomes - que não o de um escritor - para ilustrar sua investigação sobre as relações culturais entre o Brasil e a França. É o que se verifica abaixo:

O Visconde de Nogueira da Gama, que, não sendo propriamente um escritor, deve ser considerado um intelectual, foi um dos poucos, no referido período, a dar um depoimento de suas andanças pela Europa. (BROCA, 1979, p.203)

Dessa forma, "Um brasileiro na Europa em 1855", crônica de 1960, recolhida em Românticos, pré-românticos e ultra-românticos, abordará a estada do Visconde de Nogueira da Gama $^{29}$ na Europa, intelectual, segundo Broca, que deixou relatadas suas três visitas ao Velho Mundo no livro Minhas Memórias, publicado em 1893.

Valendo-se sempre de uma escrita sintética, logo de saída vê-se um cronista preocupado em informar o público sobre a fonte de sua consulta, não deixando nem mesmo de indicar a divisão de capítulos feita na obra do Visconde, fato que proporciona ao leitor um texto que caminha bem rente aos depoimentos prestados por mais um brasileiro em terras europeias.

\footnotetext{
${ }^{29}$ Nogueira da Gama (1802-1897) pertenceu a uma antiga e muito importante família de políticos e abastados proprietários rurais de Minas Gerais. Serviu como alferes na guarda de honra de D. Pedro I, ajudando a apaziguar algumas revoltas mineiras. Foi presidente da Câmara de Ouro Preto e deputado por Minas Gerais. Mais tarde, tornou-se conselheiro imperial e veador, título dado àqueles que eram considerados cidadãos nobres ou que fossem provenientes de famílias nobres, cabendo-lhes servir à rainha ou à imperatriz no paço ou fora dele.
} 
O livro, portanto, divide-se em três partes, tratando cada uma delas, respectivamente, dos três períodos em que Nogueira da Gama esteve na Europa. Essas partes, por sua vez, subdividem-se ainda em capítulos que, como indica o cronista, são compostos por cartas dirigidas ao Brasil.

Daquelas escritas durante a primeira excursão do Visconde, apreendem-se impressões e relatos da visita feita a Portugal em março daquele ano, cujo destaque é o encontro de Nogueira da Gama com a esposa de D. Pedro I, por quem foi primeiramente recebido ${ }^{30}$. A imperatriz Amélia, segundo Brito Broca, "não escondia [...] ressentimento [...] contra os brasileiros" (BROCA, 1979, p.203) em razão dos acontecimentos que culminaram no 7 de abril $^{31}$. Nesta, que seria a primeira das cinco cartas enviadas da Europa pelo Visconde, há ainda referências a uma visita feita à cidade de Cintra, em que se compara esta ao Rio de Janeiro, capital do império. Em seguida, o cenário desloca-se para a França, de onde Nogueira da Gama envia mais três cartas.

A chegada do brasileiro a Paris, em junho de 1855, coincide com o período da Exposição Internacional, fato que leva o brasileiro a considerar tudo muito caro na cidade: "paga-se muito e come-se pouco" (Idem, p.204). Broca, por sua vez, não deixa de relatar uma das poucas referências sobre literatura feita por Nogueira da Gama. Trata-se do episódio em que o Visconde,

Bom leitor de Victor Hugo e de Eugène Sue, procura logo subir à torre mais alta da Notre Dame, para circular a vista pela cidade, e no meio dos 395 degraus que ali o conduzem, dá uma "furiosa umbicada" no escuro com um vulto que lhe parece a alma penada de Quasímodo. Depois, vai percorrer os "becos sombrios e tortuosos" da Cité, conseguindo localizar o n ${ }^{\circ}$, da Rue aux Féves, onde o autor d'Os Mistérios de Paris situou vários episódios do romance. (BROCA, 1979, p.204)

Vale ainda observar como se dá essa passagem na obra de Nogueira da Gama:

Causou-me esse prazer um bom susto, porque, em meio, pouco mais ou menos, dos 395 degráos que ali conduzem, ás escuras, dei uma furiosa embigada em

\footnotetext{
${ }^{30}$ D. Pedro I encontrava-se doente na ocasião e pediu ao filho, Rei D. Pedro V, para que recebesse Nogueira da Gama. Dentre os assuntos discutidos estavam: a viagem do Visconde à Europa e os elogios à "Confederação de Tamoios, do Dr. Gonçalves de Magalhães, e da Nebulosa, do Dr. Macedo, que muito têm agradado à Sua Majestade." (NOGUEIRA, 1893, p.17). Broca, a respeito desta última informação, observa que certamente D. Pedro II era quem havia recomendado a leitura ao sobrinho, pois, como afirma o cronista, o soberano admirava as obras.

${ }^{31}$ Aqui, faz-se referência à abdicação de D. Pedro I, assunto já relacionado em um dos artigos deste trabalho. Mais uma vez, o período turbulento e bastante importante para o Brasil é retomado, mesmo que de forma enviesada, na crônica de Brito Broca.
} 
um vulto que descia, e que, comquanto nada tenha de supersticioso, cuidei que era a alma penada de Quasimodo (...) (GAMA, 1893, p.34)

Outra observação feita por Broca ilustra a maneira como Nogueira da Gama percebe o sentimento dos franceses em relação aos brasileiros; uma vez identificado o interlocutor de sua carta, um "cunhado, militar, homem prático, sem nenhuma fantasia romântica”, o cronista, falando da visita daquele a Versalhes, relata-nos que Nogueira da Gama

\begin{abstract}
Acha espantosa a ignorância dos franceses com relação ao Brasil, julgando, salvo pouquíssimas exceções, não haver dinheiro mais desperdiçado do o que o país dispende com seus diplomatas. O brasileiro, logo ao pilhar-se em Paris se esquece da pátria, da língua e até dos nomes de batismo: qualquer José ou Manuel passa a ser Le Chevalier ou Le Commandeur. (BROCA, 1979, p.204-5)
\end{abstract}

Não é tarefa difícil imaginar o que pensavam os franceses a respeito desses representantes que, por vezes, mantinham algum tipo de convivência. Mais do que mostrar propriamente a visão dos franceses a respeito do Brasil ou dos brasileiros, a ênfase aqui é dada à postura de deslumbramento assumida por aqueles que, à custa da oportunidade oferecida pelo governo, representavam o país ou até mesmo chegavam a estabelecer residência fora dele por determinado período. Em sua leitura, Brito Broca destaca ainda que no período em que o Visconde permaneceu por lá, podia-se encontrar muitos brasileiros, "principalmente das províncias do Norte, bastando uma volta pelos boulevards para encontrálos, sempre em grupos" (BROCA, 1979, p.205).

A terceira carta traz o registro da rápida visita feita a Londres. Nela, Brito Broca observa o equívoco do brasileiro ao comentar o número de habitantes daquela capital - doze milhões e trezentos mil - cálculo um tanto exagerado, afirma ele, uma vez que "nem hoje "2 $^{32}$ Londres possui essa população" (BROCA, 1979, p.205). O cronista revela ainda um episódio curioso que se passou com o Visconde, que também registraremos aqui, porém utilizando as próprias palavras daquele que de fato vivenciou a situação. O convite para uma soirée é o tema do episódio. Vejamos:

Dias depois, recebemos uma carta do Grand Chambellan, convidando por ordem do imperador madame la Comtesse de Nogueira e mr. Vasco da Gama para uma soirée no paço das Tulherias. Que lhe parece! minha mulher condessa de Nogueira, e eu Vasco da Gama! Está visto que lá não fomos, até porque podiam perguntar-me se era eu o mesmo indivíduo, ou, pelo menos, descendente do grande descobridor das Índias. Não acredita? pois ouça: Os jornaes que publicaram os nomes das pessoas notables que, durante a semana, tinham chegado a Paris, dizem entre outras: $m r$.

\footnotetext{
${ }^{32}$ Essa crônica, vale lembrar, é de 1960.
} 
Vasco da Gama, Chambellan de Sa Magesté l'Empereur du Brésil, et mr. da Costa, Charge d'Affaires". (GAMA, 1893, p.47)

Ao que vemos, Nogueira da Gama encarou a situação com bom humor. Em contrapartida, essa inadvertência não deixa de ser um exemplo da falta de conhecimento sobre o Brasil que, para o estrangeiro, ao que tudo indica, não ia muito além dos estereótipos da época em que se relacionavam o país à ideia de exotismo, fosse ele de sua gente ou de sua natureza.

É da França, no entanto, que Nogueira da Gama partirá todas às vezes para realizar suas visitas a outros países da Europa. A carta de 31 de julho, por exemplo, de Viena "dá conta do longo percurso feito através da Bélgica e depois da Alemanha, para chegar àquela cidade". Nela, Nogueira da Gama "mostra-se entusiasmado com os prodígios que as estradas de ferro têm realizado na Europa, aludindo às vantagens que elas trariam para o Brasil" (BROCA, 1979, p.205).

As impressões presentes na obra do Visconde, é preciso esclarecer, assemelham-se àquelas feitas durante uma viagem turística, em que se procuram sempre os pontos mais conhecidos de determinada localidade; não se vinculam, portanto - afora a visita à família real -, a nenhum caráter investigativo ou até mesmo oficial.

Acompanhado da família, Nogueira da Gama ainda visita Trieste e Veneza, a qual faz esta pequena observação: "Não admira pois, que com pezar a deixássemos na manhã do dia 7 , depois de lhe dirigirmos por último adeus estas palavras de Byron: 'Venice! If y a nothern wanderor weep for thee whas shuld theysons do?" (GAMA, 1893, p.64) ${ }^{33}$. O comentário parece não seduzir Broca que, por sua vez, prefere comentar que esta se tratava da última e mais longa carta escrita pelo brasileiro,

(...) uma vez que o autor a encompridou, juntando às opiniões pessoais trechos extraídos do guia de viagem sobre templos e monumentos de Roma. Nela devemos destacar a descrição de uma acidentada excursão ao Vesúvio, onde o viajante, a família e os companheiros correram o risco de morrer asfixiados. (BROCA, 1979, p.205)

Não só esse último comentário quanto o restante do livro parecem impulsionar o cronista a tocar adiante seu mapeamento. Com efeito, Broca encerra seu artigo, observando que no ano de 1855, a França estava em guerra com a Rússia e que "Nogueira da Gama

33 "Veneza, se eu, peregrino do Norte, estou chorando, o que devem fazer os teus filhos?" 
apenas se refere de passagem ao fato. A luta na Criméia $^{34}$ não perturbava a vida da Europa" (Ibidem).

Estivesse o cronista atrás de assunto ou mesmo interessado em explorar a temática que tanto lhe aguçava a curiosidade - como acreditamos que o fosse -, fato é que a obra de Nogueira da Gama pouco pode oferecer à investigação sobre as relações culturais entre brasileiros e franceses, uma vez que se pauta demasiadamente nas suas impressões de viagem de turismo, deixando poucos atrativos àquele que busca compreender melhor as influências francesas no país.

Não é de se estranhar, portanto, que a segunda parte da obra não cause interesse ao cronista. Traz o título "Recordações da minha vida escolástica", em que são expostas diversas correspondências entre o Visconde, Dr. Saldanha da Gama, Frei Francisco do Monte Alverne (que havia sido seu professor no Colégio São José, Rio de Janeiro) e outros. Há também um registro de sua segunda viagem à Europa, em 1861, mediante orientação médica. Acompanhado novamente da família, o relato é feito a partir do turismo realizado nas cidades de Lisboa (pontos históricos) e Coimbra (universidade) em que relembra o poeta Claudio Manoel da Costa, José Alves Maciel (seu tio-avô, como lembra), os Alvarengas etc. Não obstante, verifiquemos os verdadeiros motivos que levaram Nogueira da Gama a mais uma viagem:

Graças aos abalos e ás fadigas por que passei, durante os calamitosos dias da rebellião de $1842^{35}$, tinham-se aggravado os meus antigos incommodos de fígado; mas, logo que passamos a Linha, e baixou a temperatura, desapparecêram, como por encanto, todos esses incommodos, e cheguei á Lisboa completamente restabelecido. (GAMA, 1893, p.160)

Embora não saibamos precisar o nível de envolvimento de Nogueira da Gama, conclui-se que fora o bastante para lhe abalar a saúde e o levá-lo a procurar novos ares para ver-se novamente restituído fisicamente.

\footnotetext{
${ }^{34}$ Localizada ao sul da atual Ucrânia, a região da península da Crimeia foi palco de um conflito que se estendeu de 1853 a 1856, envolvendo a Rússia (país que tentava expandir sua influência nos Balcãs, região entre o mar Negro e o mar Mediterrâneo), e a coalizão integrada por Reino Unido, França Império Otomano e o reinado de Sardenha (na Itália).

${ }^{35}$ A luta contra o Império centralizado (o golpe da maioridade há pouco instituíra D. Pedro II ao trono) durante o Segundo Reinado fez eclodir, em maio e junho de 1842, algumas revoltas liberais em províncias como São Paulo e Minas Gerais, além de Alagoas, Rio Grande do Sul, Rio de Janeiro e Pernambuco alguns anos mais tarde. Figuras importantes como a do Padre Feijó e Campos Vergueiro, em São Paulo, e Limpo de Abreu e Teófilo Ottoni, em Minas, destacam-se como líderes do movimento.
} 
A terceira e última parte da obra também não chama a atenção de Brito Broca. Intitulada de "Terceira viagem à Europa em 1871, acompanhando S.M. Imperial o Sr. D. Pedro II", traz somente o itinerário percorrido em companhia do monarca, passando por Lisboa, Espanha (trajeto feito de trem e que desperta bastante a atenção do Visconde) e França (Paris e Nimes). 
Artur de Oliveira e Victor Hugo (1870)

Nesta crônica Brito Broca apresenta a seus leitores uma figura curiosa de nossa vida literária: Artur de Oliveira. Este que, debaixo de certa polêmica fora homenageado pela Academia Brasileira de Letras como patrono de uma de suas cadeiras - muito embora não tivesse deixado nenhuma obra - foi motivo de um ensaio biográfico realizado por Felipe Vieira Souto, em 1935, trabalho sobre o qual Broca se debruçou para compor seu texto. Nele estão registrados traços da personalidade desse homem que, segundo é depreendido, teria tido amizade com alguns escritores franceses.

$\mathrm{O}$ artigo encontra-se reunido em Naturalistas, parnasianos e decadistas. Segundo indicações contidas nesta obra, o texto teria aparecido no jornal carioca $A$ manhã, no dia 5 de agosto de 1951, cem anos depois do nascimento do próprio Artur de Oliveira. Intitulava-se, na ocasião, "Artur de Oliveira - Homem Curioso".

Este não era um nome muito familiar entre os leitores, lembra Broca. Certamente por essa razão é que ele desenvolve um trabalho investigativo muito sustentado por cenas da vida literária desse escritor. Uma das primeiras expostas pelo cronista envolvendo o nome desse "homem curioso" diz respeito à sua indicação como patrono a uma das cadeiras da Academia Brasileira de Letras. Assim, informa-nos Brito Broca que,

Quando, na fundação da Academia Brasileira de Letras, se tratava de escolher os patronos das respectivas cadeiras, Filinto de Almeida optou pelo nome de Artur de Oliveira, do qual ninguém se lembrara, pois que não deixara obra alguma. Dizem que Machado de Assis se levantou muito comovido e abraçou Filinto pela escolha. Machado fora um grande amigo de Artur de Oliveira e regozijava-se imensamente em ver-lhe o nome incluído na lista dos patronos. (BROCA, 1991, p.54)

Sobre a proximidade existente entre Machado e Oliveira, o cronista prossegue, valendo-se de Afrânio Peixoto, para relatar “uma versão um pouco diferente do caso”. Assim, conta que

Teria sido o próprio autor do Dom Casmuro a insinuar a Filinto de Almeida o nome de Artur - figura inteiramente obscura -, enquanto ele, Machado, preferia ficar sob a égide de José de Alencar. Não sabemos até onde está com a razão a malícia de Afrânio. O fato é que sempre causou estranheza a muita gente essa cadeira da Academia, patrocinada por um escritor do qual ninguém conhecia a obra. (BROCA, 1991, p.54) 
A amizade, que de fato houve entre os dois escritores, pode ser confirmada por Luiz Felipe Vieira Souto, no prefácio de seu estudo biográfico em que comenta o caso, não sem estranhá-lo também. Diz ele:

Uma das mais estranhas faces da vida de Artur de Oliveira, foi a amizade e admiração votada a ele por Machado de Assis. Duas naturezas tão diversas, tendo a se repelirem quase tudo; uniram-se fortemente, fazendo que dentre todos os panegiristas de Artur de Oliveira, seja o burilador de "Dom Casmurro", o que com mais veemência, abandonando o habitual retraimento deu mostras de incontida veneração e pungente saudade. (SOUTO, 1935, p.16)

Com efeito, a aproximação dos dois escritores haveria de causar surpresa entre muitos em razão da personalidade de cada um. Machado, como indicado acima, era mais retraído, ao passo que Oliveira tinha na expansividade um de seus maiores traços. Na biografia feita por Souto, verifica-se que Artur de Oliveira foi "daqueles indivíduos que impressionam e agradam de preferência às senhoras de sociedade, por darem vida e brilho às recepções (...)" (Ibidem); descrição que também concorre para ilustrar um quadro indicado por Brito Broca ao se referir a tipos como o surpreendente amigo de Machado de Assis. Assim, o cronista nos informa que:

\begin{abstract}
As mesas de café, os salões, os vestíbulos dos teatros, todos os recintos em que se cultivava outrora a palestra, como um verdadeiro gênero literário, consagrando os autores de um mot d'esprit ou de um paradoxo, criavam situações propícias a tais "realizações", com as quais se contentavam num meio onde a Literatura tinha qualquer coisa de marginal. (BROCA, 1991, p.56)
\end{abstract}

Artur de Oliveira não só costumava frequentar esse tipo de salão, como também teve o seu. Conta Luiz Felipe Vieira Souto que durante sua "curta convivência conjugal, [o escritor] manteve animado salão literário, onde às recepções afluíam os maiores escritores da época”. Informa ainda que Oliveira "era sempre, onde estivesse, a figura central para que convergiam todas as atenções, pela originalidade nova que dava aos seus discursos" (SOUTO, 1935, p.16).

É interessante notar que os primeiros movimentos do cronista nesse artigo nos remetem ao trabalho de alguém que está à procura de informações mais precisas a respeito de um escritor "agráfico", como o foi Artur de Oliveira. O mesmo processo pode ser observado em Luiz Felipe Vieira Souto quando fala de sua diligência por juntar o maior número possível de informes sobre o escritor. A tarefa, conta o biógrafo, foi difícil, pois eram "raras as produções encontradas, discordantes os depoimentos dos que sobre ele escreveram, 
flagrantemente errados alguns e deficientes todos" (Ibidem). Esse estado peculiar de escritor sem uma produção minimamente mais sólida, leva muitos a se questionarem sobre a real relevância do nome de Artur de Oliveira à literatura. Tal condição leva o próprio Vieira Souto a afirmar: "Chamavam-no e ainda o chamam de poeta, mas ninguém viu até hoje um verso seu sequer". Brito Broca vem alimentar ainda mais essa querela para seus leitores:

Chegou a haver uma discussão azeda entre Osório Duque Estrada e Francisco Prisco por ter este perguntado uma vez o que fizera a Academia dos versos de Artur de Oliveira. Artur nunca escrevera versos - respondeu Osório. Ao que retrucou, iracundo, Francisco Prisco, argumentando com uma citação de Alfredo Pujol e de uma poesia de Machado de Assis, em que este, traçando o perfil de Artur, o classificava de "poeta enorme". (BROCA, 1991, p.55)

Brito Broca afirma que ninguém conhecia os versos de Artur de Oliveira e que Machado, na verdade, "referia-se ao feitio do homem, à natureza excepcional desse espírito fora da bitola comum, vivendo sempre no mundo do sonho e da fantasia". Diante disso, somos levados a observar o pequeno mosaico que vai sendo construído pelo cronista, de tal modo que aos nossos olhos começam a se delinear os primeiros traços da figura de Artur de Oliveira. Age assim até chegar a algo mais substancial que no caso seria o ensaio biográfico sobre o escritor, como se pode constatar a seguir:

Afinal, em 1935, apareceu um ensaio biográfico de Luís Felipe Vieira Souto sobre o desconhecido patrono da cadeira de Filinto de Almeida e viu-se logo que se tratava de uma vida curiosíssima, das mais curiosas da nossa literatura, capaz de oferecer palpitante modelo a qualquer romancista. (BROCA, 1991, p.55)

Luiz Felipe Vieira Souto seria o responsável também pela publicação de Dispersos, os escritos "tão reclamados de Artur de Oliveira", que, segundo o cronista, vieram "revelar que o escritor estava longe de ser o que muitos afirmavam - tratando-se mesmo, no caso, de um destino literário fracassado". Isto, lembra Broca, em relação ao poeta. O homem, contraditoriamente, "era, na verdade, original e digno de todo o interesse".

Broca parece por fim ter encontrado aquilo que buscava: uma fonte mais segura pela qual poderia apresentar Artur de Oliveira a seus leitores. O entusiasmo do cronista se deve em razão dos Dispersos do autor virem acompanhados de sua correspondência ${ }^{36}$, fato que, segundo ele, lhe permitiria reconstruir, de modo geral, "a existência bem característica de uma época de boêmia, ainda sob o influxo do Romantismo".

\footnotetext{
${ }^{36}$ É importante lembrar que Luiz Felipe Vieira Souto também se valeu da correspondência de Artur de Oliveira no ensaio biográfico sobre o escritor. Ele a recebeu, juntamente com outras informações, do próprio irmão de Oliveira.
} 
Desse ponto em diante, o relato ganha certa ordem cronológica, em que é possível localizar de forma pontual os acontecimentos mais relevantes da vida de Artur de Oliveira. Diríamos, portanto, que temos a crônica em sua acepção mais direta, ou seja, uma narração histórica subjugada à sequência de fatos. Vejamos como isso se opera no texto:

Muito jovem, quando começava a aproximar-se dos poetas e escritores da Corte, Artur de Oliveira foi internado pelo pai no Colégio do Caraça, em Minas. O pai não queria vê-lo transformado num literato, o que na época queria dizer um boêmio, sem eira nem beira. (...)

Dentro de um ano, devido a um incidente de disciplina - pois Artur era essencialmente impulsivo e temperamental -, o jovem deixa o Caraça e vai para o Recife, sob o pretexto de que só ali poderá fazer os estudos que deseja. Reprovado, segue para a Alemanha, a mando do pai, a fim de matricular-se na universidade que cursara Goethe. Artur chega a Paris. (BROCA, 1991, p.56)

A chegada em Paris é outro ponto alto da crônica. Vê-se aqui maior preocupação em mostrar como transcorre o período da vida do escritor, agora em solo europeu.

Vale lembrar, no entanto, que o trabalho do cronista acabava muitas vezes tendo de se curvar ao espaço que lhe era concedido no jornal, circunstância que certamente o obrigava a poupar seus leitores de alguns detalhes em seus relatos.

De fato, como apontou Brito Broca, em 1870, Artur de Oliveira deixou Recife para ir estudar na Alemanha, cumprindo as ordens do pai. Porém não o fez porque "ignorava completamente a língua alemã, não sendo possível sem sabê-la bem, cursar uma escola superior" (SOUTO, 1935, p.63). Acresce-se ainda que a França vivia os primeiros dias da guerra franco-prussiana, o que dificultava mais sua mobilidade e o obrigava a permanecer em Paris; um evento que não poderia ter se dado, segundo esta explicação de Souto:

\footnotetext{
Mandaram-no para a Alemanha, via França, o que foi absurdo e perigoso, por não ter passagem e por tê-lo tornado entusiasta dos Franceses; ele, que falava correntemente o idioma, que conhecia a literatura perfeitamente, que tinha nas veias os ímpetos da latinidade, irmanou-se aos Parisienses e sentiu-se empolgado pelas paixões do momento. (SOUTO, 1935, p.63)
}

Brito Broca, possivelmente valendo-se da fonte acima, relata o "incidente" em sua crônica, acrescentando que Artur de Oliveira teria sido "um dos primeiros exemplos de intelectual brasileiro fazendo amizade no meio literário. Certamente, como uma curiosidade exótica vinda dos trópicos" (BROCA, 1991, p.56).

Permanecendo Artur de Oliveira em Paris, na biografia feita por Luiz Felipe Vieira Souto, o que se verifica é uma série de cartas destinadas ao pai, nas quais o escritor relata os 
acontecimentos vividos por ele durante os nove meses que viveu na cidade. Comunica-o, portanto, de suas relações com Gustave Laforgue, redator do Figaro, o qual the teria apresentado aos escritores Dumas (pai), (Jules) Sandeau, (Victorien) Sardou e um outro, cujo nome completo Souto afirma estar dilacerado no original. Sabe-se apenas que seu prenome era Henri. Também teria estabelecido amizade com o "sábio helenista Leconte de Lisle", embora não sejam indicadas as circunstâncias dessa aproximação.

Outras missivas, também dirigidas ao pai, porém sem resposta alguma, foram enviadas de Berlim e datam de 1871, depois do fim da guerra. Achava-se, então, o escritor entre os alemães e dentro de um território onde não conseguia se adaptar de modo algum. Em suas cartas desfilam pedidos de permissão para voltar a viver em Paris, uma vez que, argumentava ele, identificava-se muito mais com esse lugar.

O desprezo do pai, juntamente com o desejo de retornar à capital francesa, agem de forma tão intensa sobre o escritor que este, "aborrecido e indignado contras as manifestações jubilosas pela vitória alemã”, chega a tomar uma decisão bastante arriscada, como nos informa Souto:

Estacionava ele, defronte do Hotel Central, em Berlim, durante o desfile, entre aclamações uníssonas, das tropas vitoriosas que chegavam dos campos de batalha, e incontido, com voz retumbante, deu vivas à França. O escândalo foi tremendo, enorme. A prisão do aloucado brasileiro, imediata. (SOUTO, 1935, p.75-6)

Somente com essa atitude "teatral, única, inconsequente e imprevista" veio a oportunidade de se ver livre da Alemanha. O fato, afirma Souto, "teria tido consequências gravíssimas, se não fora a intervenção diplomática do conselheiro Viana de Lima, ministro brasileiro em Berlim" (Ibidem).

Brito Broca também nos informa de todo esse episódio, embora não se prenda a alguns detalhes. Vejamos:

Terminada a guerra, Artur parte para Berlim, em cujo ambiente não consegue adaptar-se, escapando de ser fuzilado por haver dito "Viva a França", no momento em que desfilavam tropas prussianas vitoriosas. Expulso da Alemanha, sem maiores consequências, graças à intervenção diplomática, retorna a Paris, onde passa a enfrentar uma vida de dificuldades, porque o pai lhe restringe a mesada e termina cortando-a. (BROCA, 1991, p.57)

Como se pode perceber, à síntese do cronista parece não faltarem os elementos essenciais do ocorrido a Artur de Oliveira. Embora não fique muito claro que a ofensa aos 
alemães tratava-se de algo já premeditado, entende-se que o escritor brasileiro conseguiu atingir seu objetivo de retornar a Paris, sem grandes complicações - por conta da intervenção do diplomata -, e sem o auxílio do pai - o qual era favorável à permanência do filho em Berlim. O cronista aproveita ainda para, na sequência, informar o leitor das condições em que Oliveira passa a viver de volta à França. Isso feito, parte para as considerações finais, encerrando o relato cronológico sobre o escritor.

Antes, porém, de verificar o desfecho da história junto com Brito Broca, convém retroceder alguns parágrafos de seu artigo ao ponto em que relata para seu público a aproximação de Artur de Oliveira, Victor Hugo e Théophile Gautier. Vejamos:

Conta-se que indo à casa de Victor Hugo, e impedido de entrar pelo criado, fez
tamanha algazarra que o autor d'Os Miseráveis saiu à janela procurando saber do
que se tratava e acabou recebendo-o. O père de la foudre tê-lo-ia chamado Victor
Hugo. Théophile Gautier dar-lhe-ia a antonomásia de mon bon sauvage. (BROCA,
1991, p.56-7)

A aproximação, como se percebe, não seguira qualquer tipo de protocolo. Muito pelo contrário. Souto, que também relata o episódio, conta que Artur de Oliveira quando retornou da Alemanha desejava intensamente conhecer Victor Hugo, “cuja atuação nos acontecimentos de 1870, havia elevado a culminâncias jamais atingidas por um escritor francês" (SOUTO, 1935, p.76). O biógrafo nos informa que ao se dirigir à casa de Hugo, o brasileiro havia sido informado pelo porteiro de que o escritor não se encontrava. Artur de Oliveira, retornando outras tantas vezes à residência de Victor Hugo, acaba por espancar o porteiro quando percebe que este, na verdade, o ludibriava. "O barulho foi grande e Victor Hugo, em pessoa, assomou à porta. Artur, imediatamente ante o seu ídolo, caiu de joelhos, declamando versos das Contemplations, naquele francês tão puro que ele sabia falar" (SOUTO, 1935, p.76-7). Após essa passagem, Souto nos informa que Victor Hugo chegou várias vezes a receber Oliveira em sua casa.

Brito Broca, por sua vez, tece algumas considerações a respeito da veracidade desse episódio. Vejamos de que maneira:

\footnotetext{
Mas não se sabe, ao certo, até que ponto tais escritores permitiram intimidades com o jovem e turbulento intelectual brasileiro. O único depoimento que temos nesse sentido são as cartas de Artur e este era um exagerado, deixando-se levar muito pela imaginação. (BROCA, 1991, p.57)
}

A personalidade do escritor, portanto, acaba por levar Broca a não devotar total credibilidade ao ocorrido. Em contrapartida, Souto afirma não ter encontrado "da mão de 
Artur" qualquer relato a respeito desse episódio; o biógrafo teria, na verdade, se pautado em "informações orais de pessoas fidedignas" que o levaram a crer na ocorrência desse fato. Sendo assim, uma questão torna-se inevitável: teria Brito Broca encontrado outra fonte para essa pesquisa que não aquela, a do biógrafo de Artur de Oliveira? Sabe-se que o cronista também utilizou a coletânea de textos do escritor, há muito reclamada, na qual também constava a correspondência com o pai. No entanto, se a biografia de Artur de Oliveira não tivesse sido obra de Luiz Felipe Vieira Souto, esse desencontro de informações poderia ser posto de lado, pois é incongruência pensar que o biógrafo não tomasse conhecimento de um relato dessa relevância contido em uma correspondência cuja organização havia sido realizada por ele próprio.

Das dificuldades pelas quais Artur de Oliveira passou quando retornou da Alemanha, ambos, Broca e Souto, dão-nos conta. Por ter desrespeitado sua vontade, o pai do escritor havia lhe retirado o auxílio financeiro, atitude que o deixou em difícil situação na França. Quem tentou socorrê-lo foi o escritor Villiers de l'Isle Adam, o qual, afirma Souto, "viveu sempre na mais negra miséria, apesar do nunca desmentido orgulho de nobre de antiga raça" (SOUTO, 1935, p.78). Mesmo assim, o poeta não deixou de escrever ao pai, dando a ele notícias de suas relações com "celebridades". Vejamos um trecho da carta, reproduzida por Souto:

\footnotetext{
"Frequento as casas dos snrs. Leconte de Lisle, o tradutor de Homero e um dos poetas mais sábios e distintos da França, Catulle Mendès, onde vai de quando em quando Théophile Gautier, Victor Hugo, Vacquerie e outros homens distintos e velhos. Tenho sido felizmente bem conceituado por esses homens que faziam a minha admiração e a alegria e contentamento dos nossos poetas e grandes homens". (SOUTO, 1935, p.80)
}

Extintos, no entanto, seus recursos, a única solução é retornar ao Brasil. Em uma última tentativa, Artur de Oliveira "chega a reclamar do pai a parte que lhe compete na herança materna" (Idem, p.81); apelo inútil visto que seu pai permaneceu irredutível. Dessa forma, as esperanças do escritor dirigem-se a um amigo da família, no Brasil, o qual consegue convencer o comandante Oliveira a ajudar o filho a retornar para o país.

Ao cronista que relatava a temporada desse brasileiro na França, a história de Artur de Oliveira praticamente se encerra aqui. Aos leitores que se interessaram pela biografia desse escritor, fica sugerida a sua permanência na mesma vida boêmia, pois, como destaca Brito Broca, ao retornar da Europa, “Artur torna-se personagem indispensável à rua do Ouvidor". 
Ainda consta nesse último parágrafo da crônica, a informação de que Oliveira chegou a escrever alguns folhetins para jornais do Rio de Janeiro. Entretanto, afirma Broca,

Não deixou obra, foi verdadeiramente agráfico, mas na sua correspondência encontramos os delineamentos de um perfil humano muito vivo, por onde se justificam a admiração e a amizade de Machado de Assis. (BROCA, 1991, p.57)

O cronista, por fim, retoma a amizade dos escritores, justificando mais uma vez sua existência em virtude da figura curiosa e expansiva que foi Artur de Oliveira.

Para nós, ainda resta uma dúvida a respeito da referência bibliográfica para essa crônica. No episódio envolvendo o escritor brasileiro, Victor Hugo e Théophile Gautier, a origem das informações prestadas por Brito Broca é diferente daquela utilizada por Souto. $\mathrm{O}$ cronista teria extraído a informação da correspondência (organizada por Souto) entre Artur de Oliveira e o pai, ao passo que Luiz Felipe afirma ter se baseado em fontes fidedignas para reconstruir essa passagem. 
França Júnior na Exposição Internacional de Paris (1878)

Publicada no Boletim da Associação Brasileira de Imprensa, em setembro de 1961, a crônica "Um folhetinista brasileiro em Paris", recolhida em Naturalistas, parnasianos e decadistas irá abordar a presença do jornalista e escritor brasileiro França Júnior em Paris, no ano de 1878. Obedecendo a seu rito, Brito Broca, irá primeiramente situar o leitor a respeito das condições que envolvem o assunto posto em cena. Por esse motivo, seu artigo se iniciará falando da Exposição Internacional de Paris, realizada poucos anos depois do fim da guerra franco-prussiana:

\begin{abstract}
Em junho de 1878 inaugurava-se a Exposição Internacional de Paris. Depois do colapso sofrido com a guerra franco-prussiana ${ }^{37}$, a perda das províncias de Alsácia e Lorena, a França pretendia mostrar ao mundo que já se achava restabelecida do golpe. A Exposição ia atrair a Paris soberanos, chefes de Estado, jornalistas, artistas e intelectuais de toda parte do mundo. E Ferreira Araújo, que havia fundado há pouco tempo a Gazeta de Notícias ${ }^{38}$, resolveu enviar também um correspondente àquele grande encontro internacional. Em quem havia de recair a escolha? Em França Júnior, cronista ágil, fixador de costumes em tons humorísticos e cujos "Folhetins", reunidos em livro, estavam sendo anunciados na própria Gazeta. (BROCA, 1991, p.66)
\end{abstract}

Como já apontado algumas vezes, o primeiro parágrafo dos artigos do cronista é sempre responsável por provocar a atenção do leitor. Dessa forma, é justificável a presença constante de uma série de informações que, observadas com mais atenção, carregam consigo as chaves que auxiliarão os leitores na interpretação de seus textos.

No caso dessa crônica, o tema é a viagem de França Júnior a Paris como correspondente da recém criada Gazeta de Notícias. Note-se, entretanto, que logo de saída,

\footnotetext{
${ }^{37}$ Conflito ocorrido entre a França e a Prússia, no período de 19 de julho de 1870 a 10 de maio de 1871 . A guerra surge a partir de uma tentativa de Napoelão III de impedir o processo de expansão territorial pelo qual a Prússia vinha passando. Revoltados com a derrota e com o posicionamento do governo, a Guarda Nacional francesa juntamente com vários trabalhadores tomaram a capital francesa, estabelecendo a Comuna de Paris, movimento responsável pela reconquista da cidade. A França, após acordo de paz assinado em Versailles, foi obrigada a ceder os territórios de Alsácia-Lorena.

${ }^{38} \mathrm{O}$ periódico foi fundado em 1875. Era considerado um jornal popular para os padrões da época (final do século XIX) e, embora fosse moderado em suas posições, veiculou diversas crônicas de fundo irônico destinadas ao imperador Pedro II.
} 
Broca fornece um pouco da atmosfera que se respirava na França no período em apreço, levando, porém, o leitor a concluir - como ele próprio também o parece fazer - que a Exposição Internacional parece na verdade revestir-se de uma espécie de medidor dos abalos sofridos há pouco pelo país e que, em certa medida, ferira o orgulho francês.

Ainda a respeito desse trecho inicial da crônica, faz-se notório o tom de admiração usado por Brito Broca ao anunciar a seus leitores o responsável pela cobertura do evento. Classificado como "cronista ágil”, França Júnior ${ }^{39}$, segundo se depreende das palavras de Broca, parece ser um dos profissionais mais capacitados para verificar de perto o "grande encontro internacional" que se realizava em Paris, possivelmente em razão de sua grande experiência na imprensa brasileira, cujo fruto também é explorado no artigo em análise.

Sendo assim, parece-nos justa uma ressalva no tocante ao livro Folhetins, de França Júnior, obra em que se reúne uma série de crônicas do escritor. Sua citação, de início, nos leva a imaginar que dela teriam partido as referências para o assunto da crônica de Brito Broca, hipótese que cai por terra quando se folheiam suas páginas. Dividida em três partes, a obra de França Júnior irá discorrer sobre uma infinidade de assuntos, muitos dos quais gravitando em torno de episódios da cidade do Rio de Janeiro. O livro, que conta ainda com um estudo biográfico $^{40}$ de Artur de Azevedo, de 1906, não chega a trazer nenhum relato que remonte àquele outro apontado por Brito Broca.

Pois bem, estamos mais uma vez diante do impasse trazido pela "síntese descritiva" de Broca (lembrando novamente Antonio Candido), qual seja, a omissão da fonte utilizada por ele. Atente-se ainda ao fato de que o único rastro deixado pelo cronista parece, na verdade, querer desorientar, ou melhor, despistar qualquer desejoso dessa informação.

Outra tentativa para se descobrir qual foi a verdadeira fonte utilizada pelo cronista toma como referência seu acervo de livros doado à biblioteca da UNICAMP. Nele é possível

\footnotetext{
${ }^{39}$ Joaquim José da França Júnior (Salvador, 1838 - Poços de Caldas, 1890) foi estudante do Colégio D. Pedro II no Rio de Janeiro, transferindo residência em seguida para São Paulo a fim de cursar a faculdade de Direito. Na capital paulista, chegou a publicar alguns artigos em periódicos acadêmicos, antes de se dedicar ao teatro, gênero para o qual escreveu diversas peças ao longo de toda sua carreira. Retornando ao Rio de Janeiro, continuou exercendo suas atividades nos periódicos desta cidade, valendo-se agora de um gênero muito em voga na época: a crônica. Considerando este último aspecto, Alfredo Bosi afirma: "França Jr. terá deixado o melhor de si não ao teatro, mas à crônica jornalística dos Folhetins que evocam o Rio dos meados do século.” (BOSI, 2004, p.241)

${ }^{40}$ Esse estudo foi publicado pela primeira vez na revista Século $X X$, segundo Alfredo Mariano de Oliveira, organizador da obra.
} 
verificar todas as obras que lhe pertenceram e, dessa forma, identificar a existência de um título que poderia ter lhe servido como consulta. Foi o caso de Política e $\operatorname{costumes}^{41}$, de França Júnior que, uma vez encontrado e consultado, também nos permitiu concluir que ainda não se tratava da referência usada por Broca no episódio do folhetinista.

Essas duas tentativas, portanto, obrigaram-nos a aceitar como referência outra passagem contida na mesma crônica. Vejamos:

Falecendo nessa ocasião em Paris o bispo d. Vital, França Júnior assistiu-lhe às exéquias, e no folhetim de 18 de junho protesta contra os termos em que lhe fez $\mathrm{o}$ elogio fúnebre o padre Segur (...) (BROCA, 1979, p.68)

Essa passagem, que será analisada mais adiante, revela-nos que as referências de Brito Broca na composição desse artigo parecem ser mesmo os folhetins de França Júnior, consultados por ele em jornais da época, os quais, ao menos até onde temos conhecimento, ainda não foram coligidos em livro.

À parte esse problema, retomemos a crônica para verificarmos a leitura de Broca a respeito da presença de França Júnior em Paris.

Brito Broca conta que França Júnior partiu para a capital francesa no mês de maio. Segundo ele, aquela era "possivelmente a primeira vez que um jornal brasileiro mandava um correspondente à Europa"42 (Ibidem). França Júnior, por sua vez, afirma ter ficado bastante impressionado com a quantidade de assuntos esperando por serem enquadrados em crônicas, coisa que não se dava no Rio, onde era preciso sair-lhes à caça. Uma das únicas queixas do jornalista concerne ao tempo que se levava para publicar suas crônicas originárias da Europa, uma vez que os acontecimentos em Paris seguiam um ritmo muito mais intenso do que no Brasil; "quando se publicava no Rio um folhetim sobre determinado fato, esse fato já havia sofrido modificações, se achando o comentário superado" (Ibidem, 66-7).

É interessante notar nessa crônica que mais uma vez Brito Broca já parece trazer consigo - e faz questão de explicitar isso ao leitor - de qual fatia dos escritos de França Júnior irá servir a seus leitores: "abordaremos apenas os episódios que envolvem o Brasil e os brasileiros em Paris" (BROCA, 1991, p.67). A ideia exposta aqui parece ser a de alguém que,

\footnotetext{
${ }^{41}$ Ver referências bibliográficas.

${ }^{42}$ Como podemos verificar, a Gazeta de notícias, portanto, teria sido o primeiro jornal brasileiro a enviar um correspondente internacional à Europa.
} 
movido pela curiosidade, quer acima de tudo compreender como se davam as relações entre seus compatriotas e a capital francesa. Nesse empenho, esforça-se por apresentar a seu público aquilo que mais lhe chama a atenção, não deixando, todavia, de inserir seu próprio ponto de vista em fragmentos como este:

A cidade estava cheia de estrangeiros e era natural que os nossos patrícios pertencentes à burguesia e à aristocracia rurais, vivendo do trabalho escravo e favorecidos pela desvalorização do franco, ali figurassem em grande número. (...) Era como se estivéssemos na rua do Ouvidor. Reproduz então alguns diálogos de brasileiros, que misturando o português com o francês se referiam, frequentemente, às largas despesas que faziam, mostrando um par de luvas há pouco adquirido no "gantier", a elegância de um chapéu, ou manifestando esse chauvinismo tolo, que até hoje muitos brasileiros posam em Paris. (BROCA, 1991, p.67)

O cronista oferece, portanto, uma viva ideia do que faziam alguns dos brasileiros que se encontravam na Paris de 1878, visitando a Exposição Internacional da cidade. Tenta buscar, por meio de sua leitura, uma caracterização dos tipos que se encontravam por lá, levando seus leitores a compreender, em poucas linhas, o perfil socioeconômico dos brasileiros presentes, assim como a situação vivida pela França nesse período.

Ainda em relação a esse trecho, é importante notar uma das primeiras aparições de um Brito Broca mais crítico no tocante aos tipos que visitavam a França. Eram eles, então, representantes de uma elite que, como bem lembrou Broca, frequentemente iam gastar o dinheiro acumulado em virtude da exploração do trabalho dos negros em suas lavouras cafeeiras, que naquela ocasião ${ }^{43}$, ainda eram mantidos como mão de obra escrava em nosso país. Brito Broca chega a transcrever pequenos diálogos em que se afigura o discurso esnobe de alguns desses representantes da aristocracia do país.

A seguir, como deixa claro que sua intenção é tratar dos episódios que envolvem o Brasil e os brasileiros, o cronista parte para outro episódio que lhe chama a atenção. Trata-se do quadro A primeira missa no Brasil, de Victor Meireles ${ }^{44}$ reproduzido em Le Figaro e que causara a irritação de França Júnior.

\footnotetext{
${ }^{43}$ Como é sabido, mesmo após o tratado de 1826, feito com a Inglaterra, em que se declarou ilegal o tráfico de escravos para o Brasil, assim como o projeto de lei de 1831, criado pelo ministro da Justiça, Eusébio de Queirós, e que se converteria em lei no ano de 1850, o fluxo dessa atividade continuou intenso. O número de cativos no país, após esta última data, continuou aumentando em razão do tráfico interprovincial, ou seja, pela transferência forçada de escravos de uma região para outra. Este claro sinal de atraso, muito mal visto por países como França e Inglaterra, permaneceu até 1888, com a extinção do trabalho escravo.

${ }^{44}$ Victor Meireles de Lima (Florianópolis, 1832 - Rio de Janeiro, 1903) foi um pintor brasileiro formado pela Academia Imperial de Belas Artes. Pintou várias obras históricas, dentre elas "A primeira missa no Brasil”,
} 
Segundo Brito Broca, o fato teria incomodado França Júnior porque, apesar dos elogios feitos ao artista, o jornal francês não havia lhe indicado o nome. O correspondente, então, tomado por um sentimento de patriotismo, dirigiu-se à redação de Le Figaro para queixar-se do ocorrido.

No elegante palacete da rua Drouot, onde imperava Villemessant, recebido por um porteiro cheio de dragonas e dourados, [França Júnior] perguntou-lhe se podia falar com algum dos redatores. $\mathrm{O}$ porteiro indicou uma sala ao lado. Apareceu o redator e houve uma troca de mesuras entre os dois jornalistas. (BROCA, 1991, 68)

Broca conta que o folhetinista, antes de explicar o motivo que o levara à presença do redator, aproveitou-se da ocasião para agradecer os elogios prestados ao artista, chegando inclusive a expor uma pequena biografia de Victor Meireles. Após ouvi-lo, o francês disse-lhe que o jornal não tinha absolutamente nada com tal publicação. Na verdade, o artigo havia sido pago pelo responsável em vender as cromolitografias ao jornal. "França Júnior, cronista ágil, fixador de costumes em tons humorísticos" saiu de lá extremamente constrangido, não deixando, porém de registrar o caso bem à sua maneira, como nos transcreve Brito Broca em seu artigo. Assim, após ter ouvido a resposta do redator de Le Figaro,

Diz França Júnior ter completado mentalmente a reticência: “... e por isso o senhor vá embora, não nos venha maçar a paciência com coisas que não nos interessam; se quiser contar aos leitores parisienses a biografia do senhor Victor Meireles, faça o que o outro fez, puxe o cordão da bolsa e a nossa pena estará às ordens". (BROCA, 1991, p.68)

Brito Broca ainda observa que esse acontecimento teria sido motivo de piadas entre a imprensa daqui.

Outro fato que Brito Broca relata em sua crônica, e este está um pouco longe do tom bem humorado frequentemente empregado por França Júnior, diz respeito à cerimônia fúnebre do bispo Dom Vital, falecido em Paris no dia 4 de julho de 1878, à qual compareceu o folhetinista. Conta Broca que França Júnior,

(...) no folhetim de 18 de junho ${ }^{45}$ protesta contra os termos em que lhe fez o elogio fúnebre o padre Segur, apresentando o prelado como um mártir, que viera falecer ali

trabalho sugerido por Araújo Porto Alegre, seu mentor intelectual e diretor da Academia Imperial. Sua dedicação à arte rendeu-lhe alguns anos de estudos na Europa sob tutela do governo brasileiro.

\footnotetext{
${ }^{45}$ Note-se que as datas de falecimento de Dom Vital e da crônica de França Júnior parecem estar equivocadas, pois é fácil concluir que o texto do folhetinista foi publicado posteriormente à morte do bispo, e não o contrário, como se verifica no artigo de Brito Broca.
} 
em consequência dos maus-tratos recebidos no cárcere. França Júnior não alude à versão divulgada na França, segundo a qual o bispo, preso na Ilha das Cobras (l'île au Serpents), se achava num cubículo entre serpentes; mas as palavras do padre Segur deviam ter resultado, até certo ponto, desse pitoresco equívoco. (BROCA, 1991, p.68-9)

Por trás da escrita sintética de Brito Broca esconde-se um importante episódio vivido entre Estado e Igreja, envolvendo membros da sociedade maçônica no Brasil durante a década de 1870. Trata-se da ocasião em que o bispo de Olinda, Dom Vital ${ }^{46}$, obedecendo a uma determinação do papa $^{47}$, resolveu proibir o ingresso de maçons nas irmandades religiosas. Tal ação desencadeou uma série de descontentamentos não só por parte desse grupo como também por parte de alguns intelectuais e escritores como Rui Barbosa, Franklin Távora, Saldanha Marinho, Joaquim Nabuco e outros. Dentre os mais insatisfeitos com a medida do bispo estava o Visconde do Rio Branco, que na ocasião presidia o Conselho de Ministros, além de também pertencer à maçonaria. O conflito, que ganhou repercussão nacional, acabou por levar Dom Vital à prisão, sendo condenado em seguida. O Imperador D. Pedro II, por sua vez, concentrou nas mãos do Duque de Caxias o poder de amainar a situação (1874-1875), que só assim foi feita mediante a condição de que os bispos (Dom Macedo, bispo do Pará, também esteve ao lado do outro) envolvidos no caso fossem anistiados. É importante ressaltar ainda que o papa Pio IX acabou suspendendo as proibições aplicadas aos maçons.

O último ponto da leitura feita por Brito Broca nos relata a indignação de França Júnior mediante a ignorância de um francês colecionador de jornais, o qual, segundo o cronista, "Já possuía várias folhas brasileiras, cuja lista mostrou, faltando-lhe, porém, as seguintes: El Siglo, La Tribuna, El Telegrafo Marítimo..." (Ibidem, p.69), jornais que, após uma boa risada, França Júnior lhe comunicou não pertencerem ao Brasil, mas ao Rio da Prata. A respeito desta informação, o homem ainda teria exclamado: "Então o Rio da Prata não fazia parte do Brasil?" (Ibidem)

O recorte proposto pelo cronista, ou seja, "os episódios que envolvem o Brasil e os brasileiros em Paris", encerra-se com esse último relato. Broca, por sua vez, despede-se de seus leitores alegando falta de espaço para continuar a leitura dos folhetins de França Júnior e

\footnotetext{
${ }^{46}$ Dom Frei Vital Maria Gonçalves de Oliveira (Itambé, 1844 - Paris, 1878).

${ }^{47}$ Pio IX, tomando como base as novas diretrizes do Vaticano, a partir de 1848, condenou as "liberdades modernas" e tratou de afirmar o predomínio espiritual da Igreja no mundo. Em 1870, o poder do papa foi reforçado quando um Concílio Vaticano proclamou o dogma de sua infalibilidade.
} 
"suas andanças pela Paris ofuscante da Exposição Internacional de 1878". Este último parágrafo reforça a ideia de que a crônica dentro de seus moldes de publicação trava uma luta diária com seu próprio suporte, o jornal. 


\section{Tobias Monteiro e Émile Zola (1898)}

Inicialmente publicada no periódico A Manhã, no dia 8 de junho de 1952, a crônica "Quando um escritor brasileiro entrevistou Zola", de Brito Broca, foi acolhida no volume de Naturalistas, parnasianos e decadistas, de 1991, da editora da UNICAMP.

$\mathrm{O}$ artigo faz um pequeno balanço das relações entre escritores brasileiros e europeus. Logo no início do texto, o leitor depara-se com uma série de questionamentos feitos por Broca acerca dos escritores brasileiros que estiveram na Europa, mas que nunca deixaram relatados seus possíveis contatos com escritores daquele continente. O primeiro exemplo é o caso de Gonçalves Dias e Odorico Mendes que, segundo afirma o cronista, tanto tempo viveram na Europa, mas que não se aproximaram de escritores como Lamartine e Sainte-Beuve, seus respectivos contemporâneos. Broca chega a essa conclusão com base na correspondência de Gonçalves Dias que tanto tempo por lá permaneceu, sobretudo em Paris.

O segundo caso trata de sua entrevista com Gilberto Amado, na qual este lhe relata, após a leitura do livro de um memorialista francês, a história da amizade entre Balzac e o Conselheiro Pereira da Silva, historiador da Formação do Império Brasileiro, que estudou em Paris. Sobre a fonte de tal episódio, Broca diz que Gilberto Amado não a teria mais, tornandolhe, portanto, impossível conferir a referência. Broca informa ainda ao leitor que numa de suas releituras encontrou o relato deste possível acontecimento no livro Evolução da Prosa Brasileira, de Agripino Grieco, mas que, assim como acontecera a Gilberto Amado, não fazia alusão à fonte. ${ }^{48}$

É justamente essa falta de informação no que diz respeito à origem do episódio que faz com que Brito Broca estranhe o fato do próprio Pereira da Silva não ter deixado nada registrado sobre o ocorrido. De acordo com o cronista, Pereira da Silva havia publicado um livro de reminiscências, Memórias do meu tempo, no qual o caso de sua amizade com Balzac

\footnotetext{
${ }^{48}$ No artigo enfeixado no volume de Naturalistas, parnasianos e decadistas lê-se: “(...) embora Agripino emitisse também o nome do livro e do autor." Ora, se "emitir algo" é justamente "exprimir-se verbalmente ou por escrito" deduz-se que o cronista ou o responsável pela transcrição da crônica para o jornal ou para o livro respectivamente, cometeu um pequeno deslize; ainda que se depreenda logo em seguida que Agripino Grieco, assim como Gilberto Amado, desconhecia a fonte dessa informação.
} 
não é mencionado em nenhum de seus capítulos. Para Broca isso lhe soa estranho, uma vez que se tratava de um contato com um ilustre escritor francês.

Dando continuidade ao tema, a crônica prossegue. Broca fala agora da carta de Lamartine a José de Alencar. Aquele procurava obter no Brasil assinaturas para a obra Cours Familier de Littérature, como alternativa para seus problemas financeiros, mas, segundo Broca, quando Alencar chega a visitar Paris, Lamartine já havia falecido. O próximo é Joaquim Nabuco que, segundo ele, é uma espécie de marco sobre as notícias de contatos pessoais entre escritores do Brasil e da França. Em Minha Formação Broca encontra relatos dos encontros que Nabuco teve com Renan e George Sand, durante sua primeira viagem à Europa.

De Joaquim Nabuco o cronista segue para Artur de Oliveira, o escritor agráfico que já teria sido tema de uma de suas crônicas, no ano anterior a esta, também em A Manhã. Descreve sucintamente o envolvimento de Oliveira com figuras francesas como Victor Hugo, Théophile Gautier e l'Isle Adam; informações colhidas, segundo Broca, nas rápidas referências que o autor deixou registradas em cartas.

Outro escritor tratado nessa pequena investigação do cronista é Olavo Bilac que, em 1891, foi para a França como enviado especial do jornal Gazeta de Notícias. De acordo com o cronista, era a primeira vez que um jornal enviava um correspondente à Europa. No entanto, quase 10 anos mais tarde, numa crônica publicada no Boletim da Associação Brasileira de Imprensa, de setembro de 1961 e que também integra Naturalistas, parnasianos e decadistas, Broca afirma que o primeiro correspondente do Brasil na Europa foi França Júnior, a pedido de Ferreira Araújo que há pouco havia fundado a já referida Gazeta de Notícias. Desse modo, depreende-se que este teria sido verdadeiramente o primeiro brasileiro enviado à Europa com a missão de manter o país informado sobre o que se passava na capital francesa e não Bilac, como ele próprio havia dito na crônica que se investiga. França Junior viajou para lá em maio de 1878 para conferir de perto a inauguração da Exposição Internacional de Paris.

Ainda sobre Bilac, Broca parece indignar-se com o fato de, em pleno auge do Naturalismo no Brasil, o poeta não ter se empenhado em realizar uma entrevista com Zola. O cronista, que investiga o caso a fundo, pesquisando nos numerosos artigos de Bilac durante o período em que o poeta trabalhou para a Gazeta de Notícias ou mesmo para outros jornais e 
revistas, conclui que Bilac não teria travado qualquer tipo de relação não só com Zola como também não teve nenhum encontro com algum outro escritor francês célebre na época. Dessa forma, a entrevista com Zola fica a cargo de Tobias Monteiro e Broca a deixa para o fim de sua crônica.

Em 1898, quando a comitiva do presidente Campos Sales partia para uma visita à Europa, Tobias Monteiro, jornalista e historiador, promete entrevistar Zola. De acordo com Broca, seria o primeiro contato de um brasileiro com esse escritor que havia se tornado duplamente célebre, dada sua participação no caso Dreyfus. O Jornal do Commercio foi o veículo pelo qual Monteiro expôs seu relato. Em sua crônica, Broca nos diz que o primeiro encontro dos dois havia se dado no gabinete de Yves Guyot, diretor político do Le Siècle e amigo de Zola. No entanto, alegando outros compromissos, o romancista e o jornalista acabaram por adiar o encontro.

De fato, Broca é muito preciso nas informações que deseja repassar a seus leitores pois a leitura que realiza dos artigos de Monteiro é justamente para rastrear seus passos na direção de Zola. Assim, em $O$ presidente Campos Salles na Europa, obra onde são agrupados os artigos enviados pelo jornalista Tobias Monteiro da Europa para o Jornal do Commercio, mais precisamente nos capítulos intitulados "Visitas proveitosas" e "Entrevista com Sr. Zola", encontramos as informações que Broca nos mostra em sua crônica juntamente com outras por ele ignoradas, mas nem por isso menos consideráveis.

Dentre as visitas proveitosas citadas por Tobias Monteiro estão registrados os encontros com Hannotaux (Ministro das Relações Exteriores), Felix Faure (Chefe de Estado da França), Henri Germain (presidente do banco Crédit Lyonnais) e Yves Guyot (diretor do jornal Le Siècle). À exceção da última, todas as outras visitas foram feitas em companhia de Campos Salles. Neste capítulo, entretanto, Monteiro tem outro objetivo:

\footnotetext{
Já disse o que tem feito o Sr. Campos Sales; devo agora dizer o que procuro colher de especial para os leitores, no curto tempo roubado à minha missão particular. Quando parti do Rio, prometi ao diretor do Jornal que faria o possível para ter uma entrevista com o Sr. Zola, tão admirado hoje do mundo inteiro, pela grandeza das suas criações literárias como pela inteireza moral consagrada à questão Dreyfus. (MONTEIRO, 1983, p. 72)
}

É a partir desse momento que Tobias Monteiro nos relata como foi sua trajetória antes da entrevista com Zola. O jornalista, então, logo que chega a Paris, consegue ser apresentado ao Sr. Yves Guyot, ex-deputado e ex-Ministro das Obras Públicas, atual diretor político do Le 
Siècle e, principalmente, amigo íntimo de Zola. Tobias Monteiro nos dá um pequeno quadro da figura de Yves Guyot e de como este conseguiu lhe proporcionar o seu primeiro encontro com o escritor de L'Assomoir. Segundo Monteiro, Guyot lhe havia informado de que Zola sempre o visitava às seis e quarenta e cinco da tarde. Dessa forma, à hora estimada, ele teve seu primeiro contato com o escritor.

Confirmando o que nos diz Brito Broca em sua crônica, esse primeiro encontro entre Monteiro e Zola serviu apenas para que adiassem a entrevista, uma vez que ambos se encontravam em condições desfavoráveis para uma conversa maior. Tobias Monteiro porque seguiria no dia seguinte para Londres na sua missão de acompanhar Campos Salles e Zola porque se encontrava tomado por seus afazeres. No entanto, em seu artigo, Tobias Monteiro nos relata o modo amável pelo qual foi recepcionado por Zola e das cartas que este havia recebido do Brasil cumprimentando-o por sua atuação no caso Dreyfus. Monteiro aproveita a oportunidade para mostrar a Guyot e a Zola um número do Jornal do Commercio, cuja primeira página era quase toda destinada a esse caso. Os dois homens impressionam-se com as proporções do jornal brasileiro, com as variedades dos assuntos tratados nele e da abundância dos anúncios, alegando só haver na Inglaterra e nos Estados Unidos diários como aquele.

Tendo ficado para depois a conversa com o romancista francês, Monteiro retoma seu encontro com Guyot e a conversa que teve com ele sobre o Brasil. Broca, como já dissemos, priva seus leitores de pormenores como este em detrimento de seu objeto, qual seja, a entrevista com Zola. No entanto, não deixa de ser precioso para os estudiosos das relações Brasil-França alguns pontos tratados nesse artigo.

O tema da conversa entre Tobias Monteiro e o Sr. Guyot gira em torno dos aspectos financeiros e econômicos do Brasil. Monteiro informa a Guyot os progressos do individualismo contra o socialismo do Estado, mostra como a necessidade de achar aplicação para as novas emissões de papel-moeda havia desenvolvido o espírito protecionista de indústrias precoces e, ainda sobre protecionismo, chama a atenção dele para o exagero com que a França tributava o nosso café, enquanto no Brasil já se começava a bradar contra essa atitude. Yves Guyot demonstra apoio a essas ponderações de Tobias Monteiro e o convida para escrever um ou mais artigos no Le Siècle para que seus leitores sejam informados desses fatos, de tanto interesse para a sua escola política. Monteiro agradece ao convite e informa 
Guyot que no Brasil, Américo Werneck, havia escrito alguns artigos apoiados em seu trabalho Trois ans au Ministére des Travaux Publics.

Outro ponto que desperta a atenção no artigo de Tobias Monteiro diz respeito à queda nas exportações do café. De acordo com ele, o café entre 1894 e 1895 produzia £ 28.000.000, entre 1895 e 1896 rendia £ 21.250 .000 e entre 1897 e 1898 dava apenas £ 12.687.500. Com base nesses valores, Monteiro lembra em seu artigo que o Brasil poderia aproveitar a exposição de Paris em 1900 para fazer alguma coisa em benefício do consumo do café brasileiro na Europa. Adverte que se o Estado não pudesse custear a exposição, os fazendeiros, os comissários, os ensacadores e os exportadores poderiam formar uma associação poderosa e pedir que o governo solicitasse um local para a exposição do nosso café. De acordo com Monteiro, esse empenho faria com que milhões de visitantes vissem toda a evolução dos processos para o uso do café e se assegurariam da autenticidade e da qualidade de nosso produto. Segundo Monteiro, melhor oportunidade não teria nosso país haja vista que Paris seria o ponto de encontro de populações de todo o mundo durante a exposição.

A ideia de Tobias Monteiro fosse pela falta de interesse ou pela ousadia (ele imaginou, por meio do cinematógrafo, exibirem grandes vistas de fazendas com cafezais e dependências) acabou sendo deixada de lado, como se depreende ao fim desse seu artigo.

Como afirma o próprio Broca, a entrevista com Émile Zola se dá logo após o retorno de Tobias Monteiro de Londres. Escrito em 24 de junho de 1898, o artigo compõe o oitavo capítulo do livro de Monteiro e se intitula "Entrevista com o Sr. Zola".

A conversa ocorre efetivamente na residência do próprio escritor, à Rue Bruxelles 21, onde, segundo Broca, depois de sua condenação, "a fachada amanhecia diariamente coberta de flores e de imundices". Essas manifestações refletiam as opiniões de seus admiradores e de seus inimigos ante o caso Dreyfus, afirma o cronista.

Broca chama a atenção para o modo como o escritor recebe Tobias Monteiro: "com trajes com que saíra do quarto de dormir" e também para a referência que Tobias faz à decoração do interior da casa de Zola: um grande número de quadros pela parede, indicando que ali morava um "cultor da arte". Entretanto, verifica-se uma grande riqueza de detalhes na descrição feita por Monteiro tanto no que concerne ao escritor quanto à sua residência. Evidentemente, devido ao espaço limitado do jornal, Broca procura não se prender tanto a 
esses detalhes que, nesse caso, são pouco relevantes para seu texto. Dessa forma, o cronista parte logo para alguns pontos da entrevista que lhe são mais instigantes.

Temas como a reforma do ensino feita pelo governo francês e o caso Dreyfus são tratados por Zola a pedido do jornalista brasileiro. Brito Broca prefere não relatar os detalhes das respostas do escritor francês sobre o caso Dreyfus por acreditar que essa discussão não interessaria a seus leitores visto que o assunto havia se dado em 1898. Por outro lado, em seu artigo, Monteiro nos relata o pensamento de Zola sobre a campanha começada por Edmond Demolins que foi seguida por Jules Lemaitre contra a educação francesa. Assim, Zola, segundo Monteiro, ignorava esse movimento reformista e acreditava que toda a influência exercida pela França em todo mundo vinha sobretudo da sua língua, da sua literatura e que, portanto, não havia necessidade de submeter a nação ao aprendizado de outros idiomas. Ao contrário, segundo o romancista, convinha desenvolver o seu idioma cada vez mais para que, com a riqueza de suas letras, se conseguisse torná-lo indispensável aos outros povos.

Essa pequena discussão acaba levando Zola a dirigir algumas perguntas a Tobias Monteiro acerca de sua viagem e da organização do Jornal do Commercio, a folha brasileira pela qual o romancista havia mostrado grande interesse desde o primeiro encontro com o jornalista. Segundo o romancista, os jornais franceses não tinham o hábito de veicular anúncios como os ingleses ou os americanos; segundo o escritor, esse comportamento prejudicava o comércio e encarecia a imprensa. A conversa, segundo se depreende, prossegue até o ponto em que Monteiro nos relata que em sua viagem a Londres despertou-lhe a atenção ao grande número de anúncios espalhados pela cidade: estações, bondes, degraus de escadas, andaimes, tapumes todos aproveitados para esse fim. Ao contrário do que se via na França.

Tobias Monteiro começa então a falar da Inglaterra e aproveita o ensejo para introduzir o tema que mais lhe interessava: a intervenção de Zola na questão Dreyfus. É importante salientar que estamos em $1898^{49}$, ou seja, há 4 anos do julgamento do capitão Dreyfus pelo conselho de guerra e há poucos meses da publicação da carta de Zola, J'accuse, em Paris pelo jornal L'Aurore. Neste artigo o romancista defendia o capitão de artilharia do Estado-Maior Alfred Dreyfus, descendente de judeus alsacianos, da acusação de ser o autor de uma carta (o bordereau) que transmitia informações sobre recursos e planos de defesa do

\footnotetext{
${ }^{49}$ De acordo com a crônica de Brito Broca, o encontro entre Tobias Monteiro e Zola teria se dado em 1892. Entretanto, no livro do jornalista, o artigo registra o ano de 1898.
} 
Exército francês ao adido militar alemão em Paris, major Schwartzkoppen. Tanto a condenação de Dreyfus quanto a carta de Zola causaram muitas polêmicas no cenário sóciopolítico da França daquele período. Até mesmo entre os brasileiros, que, desde a publicação da carta de Ruy Barbosa em janeiro de 1895 pelo Jornal do Commercio, tanto se debruçaram sobre as notícias sobre l'affaire Dreyfus. É por essa razão que Monteiro credita grande valor ao assunto, tratando de registrar as palavras de uma figura como Zola que tanto se envolveu no episódio.

Confirmando as palavras de Brito Broca, Zola se achava na Itália produzindo seu romance Roma quando teve a notícia da condenação de Dreyfus. Entretanto, ao contrário do que se depreende da leitura de Broca, o escritor confessa a Monteiro que o caso, inicialmente, não lhe chamou a atenção tamanha era sua dedicação ao livro. Recorda-se apenas que ao ouvir falar do ato de degradação pelo qual passara o capitão de artilharia, sentiu na alma de romancista a beleza trágica daquela cena que teria gostado de descrever. Somente depois, quando toma conhecimento efetivo do caso e das provas que inocentavam Dreyfus, é que decide escrever a respeito. Monteiro ouve ainda do escritor que, durante esse período, quase toda a França se voltou contra ele, movida por forte paixão patriótica.

Broca em sua crônica procura não se estender muito na questão Dreyfus e a encerra antes mesmo de introduzir qualquer detalhe dessa parte da entrevista, alegando o fato de que o caso não interessaria ao leitor de seu tempo, uma vez que já estariam disponíveis várias biografias de Zola para a realização de uma pesquisa dessa natureza. Dessa forma, verificamos a precisão do recorte feito pelo cronista para continuar seguindo as pegadas que o levarão ao que lhe interessa realmente, a Literatura.

Dentro desse tema, ou seja, a Literatura, Broca busca no artigo de Monteiro informações para seus leitores sobre um novo livro que o romancista francês pensava em escrever na época. Na verdade, trata-se de Fecondité, sobre o qual lemos:

Passando para a Literatura, Tobias pede desculpa pela indiscrição de jornalista, mas desejava saber se Zola não pretendia escrever um novo romance. Depois de procurar furtar-se à declaração, o escritor acaba dizendo que tencionava tratar do importante problema do decréscimo de natalidade na França. E esse romance, como se sabe Zola o escreveu: intitula-se Fecondité. (BROCA, 1991, p. 170) 
Neste trecho é importante destacar a habilidade de cronista que Brito Broca possui; escolhe com tal precisão as palavras que vão compor seu texto que consegue, com fidelidade, o efeito de enxugamento da informação que buscou sem nenhum prejuízo para o leitor e para o próprio espaço do jornal que será destinado à sua crônica. Observemos a fonte de Broca, como ilustração à nossa hipótese:

(...) por fim ele revelou-me o seu propósito de estudar a grave questão da diminuição dos nascimentos em França, que tanto preocupa os higienistas e os estadistas. Procurará expor a imoralidade desse fato e levantar contra os seus autores a indignação do país. Depois estudará a questão do aleitamento. Principalmente com a preocupação de pouparem-se, as mães em geral não alimentam bastante os filhos ou entregam-nos à indústria das amas-de-leite. Em consequência da nutrição incompleta, os vícios de infância minam os organismos novos e preparam o enfraquecimento da nação. (MONTEIRO, 1983, p. 108)

Como se pode observar, o texto em que Broca se orienta para compor sua crônica traz outras informações a respeito de um romance de Zola. No entanto, não lhe escapa o essencial, ou seja, o nome e o tema da obra.

Talvez o próprio Broca desconhecesse, pois possivelmente teria tratado de divulgar, mas de acordo com uma nota de roda-pé presente na edição usada para este trabalho, verificase que Tobias Monteiro teria sido o primeiro jornalista a divulgar o novo romance de Zola, em 25 de junho de 1898, data da publicação do artigo no Jornal do Commercio. A imprensa francesa, segundo consta, tomaria conhecimento da obra somente muitos meses depois, em 1899.

Outra questão levantada por Tobias Monteiro e que Broca apreende em seu texto é sobre o fato de Zola servir-se do que há de ruim na sociedade para produzir seus romances. Assim, temos:

(...) Tobias não perde a ocasião de referir-se ao que se diz a respeito do romancista: de preferir sempre retratar o que há de mau na sociedade. Nunca teve a preocupação de escolher assuntos chocantes - responde Zola. Todo seu empenho era servir à verdade e à justiça. (BROCA, 1991, p.170)

Consultando mais uma vez a fonte de Broca, verificamos que ele se apropria do próprio texto de Tobias Monteiro para prosseguir sua investigação:

Respondeu-me prontamente que nunca teve o propósito de escolher assuntos chocantes. Todo o seu empenho era servir à verdade e à justiça, e para isso colhia os temas onde a sua observação os surpreendia e quando a imaginação por eles se inflamava. (MONTEIRO, 1983, p.109) 
Aqui, como é evidente, o cronista serve-se da própria construção de sua fonte para retirar o que lhe é proveitoso. Entretanto, o que nos indaga nesse trabalho é de onde o cronista teria retirado outras informações que permeiam seu texto, pois, se ao contrário de Monteiro que segue para suas considerações finais, Broca introduz um novo fato, ou, como ele próprio chama, um parêntesis antes de encerrar sua crônica?

O fato novo que nos chama a atenção e que o cronista deixa para o final de seu texto trata-se do livro de um médico francês, Dr. Laupts, Perversions et Perversités Sexuelles. Nele Broca encontra a reprodução da confidência de um homossexual que havia sido enviada inicialmente a Zola. Ao que parece, o romancista não a considerou como tema para uma possível obra, pois contava com a certeza de que seria outro escândalo envolvendo seu nome e, por isso, enviou o manuscrito para o Dr. Laupts, que o soube aproveitar. Broca, então, finaliza esse "pormenor", colhido possivelmente numa de suas leituras, dizendo que somente Proust muitos anos depois teria tido a coragem de penetrar nesse "terreno escabroso" e, assim, o cronista fecha o parênteses e encerra seu artigo registrando que Tobias Monteiro havia se encantado "com a simplicidade e as maneiras acolhedoras de Zola".

Tal atitude nos levar a pensar que Broca se posiciona frente ao texto como um habilidoso jogador, aguardando assim, o melhor momento para dar a última cartada. 


\section{CAPÍTULO III}

\section{FRANCESES NO BRASIL}

\section{Jacques Arago e João Caetano $(1817,1850,1854)$}

Originalmente publicada no suplemento literário "Letras \& Artes" do jornal carioca $A$ Manhã, a crônica "Há cem anos, na casa de João Caetano: Jacques Arago e o Brasill, que hoje integra o volume Horas de leitura: primeira e segunda séries, é um exemplo do interesse de Brito Broca pelas relações culturais entre o Brasil e a França. Embora não se precise a data desse artigo, conclui-se que sua aparição se dera em 1954. Seu estopim é a publicação das Cartas ao amigo ausente, de José da Silva Paranhos, o Visconde do Rio Branco ${ }^{50}$ Entretanto, Broca logo adverte ao leitor que seu interesse não incidirá sobre o surgimento dessa obra, mas sobre uma referência nela encontrada na qual verifica a visita de um teatrólogo francês ao Brasil, Jacques Arago, em 1854.

Recorrendo a essa primeira fonte, constata-se que o relato da estada do dramaturgo francês entre nós encontra-se na $19^{\mathrm{a}}$ carta de Paranhos, da qual Broca se vale de parte como referência direta em seu texto. Nota-se, entretanto, que o próprio Visconde dedica-lhe menos que uma página e assim seu artigo acaba funcionando muito mais como uma espécie de “deixa" de que precisava o cronista para se lançar à pesquisa. É o que se verifica na

\footnotetext{
${ }^{50} \mathrm{O}$ livro é resultado da reunião dos artigos (folhetins) do Visconde do Rio Branco publicados no Jornal do Commercio durante o ano de 1851, no Rio de Janeiro. Com introdução de José Honório Rodrigues, nessa obra encontram-se registros da vida política, social e teatral da época.
} 
sequência. Broca, então, traçando um pequeno histórico do dramaturgo com base nas informações de Paranhos, diz:

O Jacques Arago a que alude o folhetinista era irmão de François Arago, o grande sábio francês, famoso pelas suas descobertas no terreno da astronomia. Ao contrário do irmão, inclinou-se para a literatura e principalmente o teatro. Em 1817, agregou-se à expedição das corvetas Uranie e La Physicienne, comandadas por Freycinet e demorou três anos dando a volta ao mundo, longa viagem que narrou depois no livro Promenade Autour du Monde. (BROCA, 1992, p. 224)

Em uma rápida consulta à obra de Arago, Broca recolhe a impressão do escritor sobre a biblioteca de Dom João VI. Assim, o francês observa que "com a vinda do Príncipe Regente para o Brasil já se verifica uma visível mudança de mentalidade no que se referia à censura dos livros" (BROCA, 1992, p.224). Segundo o cronista, ler Rousseau, Voltaire e Reynal no Brasil do final do século XVIII era considerado um verdadeiro crime. Ainda sobre essa visita de Arago à Biblioteca Real, é válido destacar este trecho:

No período de Dom João VI - aquele "tempo do rei”, em que Manoel Antonio de Almeida situa as Memórias de um Sargento de Milícias - Arago descreve-nos o diretor da Biblioteca Real mostrando-lhe um volume de Reynal e dizendo-lhe: - "Eis um grande pensador, senhor. Um dos vossos primeiros filósofos." E o mesmo homem copiava, no momento, certo trecho de Rousseau, para os filhos traduzirem. (BROCA, 1992, p. 225)

Causa-nos reparo, entretanto, um fragmento colhido na obra do próprio Jacques Arago, Souvenirs d'un aveugle, no qual verificamos uma das visitas do escritor à biblioteca do rei. Assim, temos:

\begin{abstract}
A Rio-Janeiro il y a une bibliothèque royale, grande, belle, et enrichie des meilleurs ouvrages littéraires, scientifiques et philosophiques des nations civilisées. J'ai eu toutes les peines de monde à me la faire indiquer, car elle est parfaitement déserte et inconnue des Brésiliens. Je l'ai visitée deux fois, deux fois je m'y suis trouvé seul avec le directeur, jeune moine aux formes polies, mais ne parlant de Montesquieu, de Rousseau, de Montaigne, de Voltaire, de Pascal, de d'Alembert et de Diderot qu'avec le plus profond dégoût. Ce directeur croit beaucoup à l'astrologie et fort peu à l'astronomie: je m'en étais douté. (ARAGO, [s.d.], p. 72, tomo 1)
\end{abstract}

Não há dúvida de que entre esses dois fragmentos existe uma discrepância de informações. Deve-se, no entanto, considerar as diferentes estadas do escritor francês em nossas terras para aceitarmos esses desencontros. Não obstante, é o próprio Broca que irá nos alertar sobre uma característica de Arago. Diz, assim, o cronista:

Mas ante a acusação de que Arago foi alvo de haver fantasiado largamente suas impressões do nosso país - como se conclui da referida "carta ao amigo ausente" ficamos no direito de duvidar da exatidão do episódio acima narrado. Quem sabe não teria o autor no caso "dramatizado" também um pouquinho?... (BROCA, 1992, p.225) 
A crônica avança e Broca mergulha um pouco mais na presença de Arago em terras brasileiras. Segundo ele, o escritor francês havia estado aqui três vezes: a primeira, como já indicada, por volta de 1817, acompanhando a expedição das corvetas Uranie e La Physicienne e que resultou no relato de viagem Promenade autour $d u$ monde $e^{51}$ no qual registram-se algumas impressões sobre o Brasil; a segunda vez se dera em 1850, a bordo da corveta Bayonnaise, comandada por Juvien de la Gravière, quando se dera a entrevista com o imperador; e a última, em 1854, quando Arago falece na residência de João Caetano.

Jacques Étienne Victor Arago nasceu em 10 de março de 1790 em Estagel, França. De 1817 a 1821 participou como desenhista da expedição de Louis C. Desaulses de Freycinet ${ }^{52}$ a bordo do Uranie, indício de que sua primeira visita ao Brasil teria ocorrido entre esses anos. Colaborou em vários jornais franceses e fez representar com êxito muitas peças ( $O$ noviciado diplomático, em 1834; O cadete de Gasconha, em 1836; etc). Em 1837 ficou cego e em 1839 publicou os Souvenirs d'un Aveugle. Arago compôs ainda um drama intitulado L'Éclat de Rire que foi representado, segundo Broca, com grande êxito em Paris pelo ator Frédérick Lemaître, e cuja cena principal recaía no momento de uma enorme gargalhada, quando o protagonista era acusado de roubo. Décio de Almeida Prado, estudioso que também se ateve ao caso da visita do teatrólogo, nos presta maiores esclarecimentos acerca da composição e da trama da peça:

\begin{abstract}
Será antes um drama burguês à maneira do século dezoito, sentimental, choroso, familiar, com alguns lances fortemente melodramáticos. O seu enredo, ao contrário do que acontece com as peças de Ducange ou Dennery, resume-se com facilidade. André Lagrange retira 1.000 francos da firma em que trabalha para salvar a vida de sua mãe, necessitada, por conselho médico, de um longo repouso numa estação de águas. Quando vai repor o dinheiro, é surpreendido e acusado de roubo. Enlouquece mas de um modo estranho, através de um ataque de riso convulsivo, frenético. (PRADO, 1972, p. 97)
\end{abstract}

\footnotetext{
51 Além dessa obra, outras duas foram produzidas: Souvenirs d'un aveugle: voyage autour du monde (s.d.) e Voyage autour du monde: entrepris par ordre du roi (1825). Esta última trata-se do rapport que Jacques Arago e outros fizeram a mando de Freycinet durante a expedição.

${ }^{52}$ A pedido do rei, Freycinet comandou a expedição que tinha como objetivo principal investigar a forma do planeta e os elementos do magnetismo terrestre; questões meteorológicas também haviam sido indicadas pela Academia como dignas de atenção. A corveta Uranie partiu de Toulon, em 17 de setembro de 1817, seguindo para Gibraltrar, Ténériffe e Rio de Janeiro, onde lançou âncora no dia 6 de dezembro e permaneceu por dois meses. Tomando o Cabo da Boa Esperança, a expedição prosseguiu para Île Bourbon, Timor, Dillé, Îles Mariannes, Îles Sandwich e Terre-de-Feu, lugar em que, antes mesmo de aportar, a tripulação fora surpreendida por uma forte tempestade que a impediu de prosseguir. Após o incidente, a expedição prosseguiu com a corveta La Physicienne e o Brasil foi novamente rota da equipe francesa, numa estada que se iniciou a 19 de junho e terminou em 13 de setembro de 1820.
} 
Esse texto, segundo Almeida Prado, garantiu a Arago uma boa carreira comercial na França. O ator dramático espanhol José Lapuerta foi quem o trouxe para o Brasil em 1843. A peça havia estreado três anos antes na França e já portava "alguma legenda: dizia-se que o seu primeiro intérprete, Francisque Ainé ${ }^{53}$, falecera em virtude do esforço necessário à famosa gargalhada" (PRADO, 1972, p.98). Para João Caetano, renomado ator brasileiro do século XIX, o drama de Arago era a espécie de desafio apreciado por ele, "propenso, por natureza, às violências interpretativas, à emoção bruta, aos efeitos físicos" (Ibidem, p.98). Dessa forma, fez traduzi-la para apresentá-la ao público brasileiro com o nome de A gargalhada, feito que lhe proporcionou "se não o seu maior papel (...) ao menos o seu êxito mais pontilhado de incidentes gloriosos" (PRADO, 1972, p.97).

A estreia de A gargalhada deu-se em maio de 1843. Conta-nos Prado que após o encerramento da peça, José Lapuerta e um médico amigo de João Caetano correram ao camarim do ator, pois acreditavam que o encontrariam com uma "artéria arrebentada", mas, em vez disso, acharam-no simplesmente cansado, repousando sobre uma poltrona. Em sua crônica, Broca diz que João Caetano, para dar verossimilhança à cena da loucura, frequentou durante algum tempo um hospital de alienados. A gargalhada, segundo ele, era verdadeiramente o grande momento da peça:

O efeito da gargalhada nervosa e convulsa foi assim plenamente alcançado. Essa peça assinalou um dos grandes êxitos de João Caetano. Dizem que certa vez, descido o pano, o ator teve de submeter-se a uma sangria para evitar um derrame cerebral! (BROCA, 1992, p.225)

A informação trazida por Broca vai perfeitamente ao encontro desta de Décio de Almeida Prado:

A gargalhada da loucura permaneceria para sempre sua maior proeza dramática. "Todo êxito do drama dependia dessa gargalhada e João Caetano dava-a de tal modo que, descido o pano, ainda se ouvia rir nos bastidores em caminho do camarim. Noites houve em que o médico do teatro achou prudente sangrá-lo, para evitar um insulto cerebral”. (PRADO, 1972, p. 98-9)

Em outubro de 1850, Jacques Arago, trazido pela corveta Bayonaise, desembarca no Rio de Janeiro. Segundo Broca, essa era sua segunda visita ao Brasil, precisamente na qual se dera o encontro entre o teatrólogo e dom Pedro II. É ainda Silva Paranhos que colhe uma pequena amostra do que foi o encontro dos dois:

\footnotetext{
${ }^{53}$ Ator que, segundo Décio de Almeida Prado, se encontrava bem abaixo na hierarquia teatral, em plano estritamente melodramático, não costumando seu nome figurar nas histórias do teatro. Era o êmulo de Frédérick Lemaître.
} 
Ouvi referir uma anedota do mesmo autor que, me parece digna de ser aqui estampada, e creio que o farei sem cometer uma indiscrição. Na entrevista com que S.M. o Imperador se dignou honrá-lo, vendo-se ele em apertos por algumas inexatidões que de sua obra citava a feliz reminiscência do seu augusto interlocutor, disse o cego historiador: "Mais, Sire, il faut toujours dramatiser". A resposta de S.M. não podia ser mais adequada: “C'est bien, mais j'espère que vous ne dramatiserez pas cette conversation”. (PARANHOS, 1953, p.105)

Arago, pelo que se depreende, era dotado de uma personalidade bastante singular. Brito Broca busca num artigo de Pires de Almeida ${ }^{54}$ um episódio ocorrido logo após sua chegada e o acolhe em seu texto:

Lembrarei apenas a circunstância por ele assinalada de que Arago era de uma voracidade extraordinária na mesa do almoço quando lhe ergueram um brinde ao irmão François ${ }^{55}$, o escritor retrucou em tom de fingida zanga: "Os senhores vivem a glosar o nome do meu querido irmão; entretanto, eu valho muito mais, pois enquanto ele não passa de um notável astrônomo eu sou um gastrônomo notável”. (BROCA, 1992, p .226)

Ao saber que João Caetano havia representado sua peça L'Éclat de Rire, sob o título A Gargalhada, Arago quis assisti-la. Segundo o cronista, o teatrólogo "Não compreendia o português e nem podia apreciar a máscara, a gesticulação do ator, mas lhe ouvia a gargalhada e isso era o bastante" (BROCA, 1992, p.226). Décio de Almeida Prado complementa quando considera "natural que João Caetano desejasse mostrar a sua interpretação de 'André Lagrange' ao visitante duplamente venerável, pelo prestígio intelectual e pelo halo de simpatia que a cegueira criava à sua volta" (PRADO, 1972, p.101). Broca, então, descreve resumidamente como se dera - não a apresentação - mas as reações de Arago e João Caetano após o espetáculo. Segundo o cronista,

Foi um verdadeiro triunfo. João Caetano recebeu em cena aberta uma corda de louros e colocou-a na cabeça de Arago; este, por sua vez, dela retirou apenas uma folha e devolveu-a a João Caetano; tudo isso entre beijos e lágrimas e outras expressões bem ao sabor da época romântica. Arago agradeceu num pequeno discurso, que alguns jornais de então reproduziram em francês. (BROCA, 1992, p.226)

Após esse breve relato, Broca parte para as considerações finais de sua crônica. Faz-se notar, todavia, o comentário de Antonio Candido a respeito da omissão das fontes utilizadas

\footnotetext{
${ }^{54}$ O cronista indica "Ilustrações Brasileiras" - outubro de 1911 como referência.

${ }^{55}$ Dominique Jean François Arago, irmão mais velho de Jacques Arago, era físico e astrônomo, tido como um dos mais ilustres sábios do século XIX. Contam-se ainda mais dois irmãos: Jean e Étienne Arago, este último autor dramático e diretor do Vaudeville (1829-1840) de quem João Caetano havia encenado duas de suas peças.
} 
por Brito Broca: o cronista não precisa exatamente de onde extrai o relato dos acontecimentos, apenas cita o nome de Lafayette Silva e sua obra quando se refere à indicação do Visconde do Rio Branco de que Arago, de volta à França, teria escrito um drama em homenagem ao ator brasileiro.

Quanto ao drama dedicado a João Caetano, que Arago teria composto ao regressar a Paris - e que pelo título, segundo supunha o autor das Cartas ao Amigo Ausente, versaria sobre coisas do Brasil - nada conseguimos apurar. Lafayette Silva (João Caetano e sua época) $)^{56}$ alude apenas a um opúsculo Foyers et Coulisses, escrito pelo teatrólogo, de volta à França, no qual recordava João Caetano, como uma das "gloires brésiliennes", comparando-o a Ligier, ator principal do Porte Saint-Martin. (BROCA, 1992, p. 227)

Em todo percurso da crônica, salvo o artigo de Silva Paranhos e o de Pires de Almeida, não se verifica de forma direta qual teria sido a fonte de Brito Broca a respeito do episódio principal ilustrado em seu texto. Esse "pudor às vezes excessivo", como lembra Candido, em determinados casos pode turvar o olhar daquele que busca um esclarecimento sobre algum fato da vida literária, escritor ou obra literária. Há de se considerar, evidentemente, que a crônica enquanto gênero não suportaria, no caso de Brito Broca, o rigor acadêmico exigido nos trabalhos hoje realizados, com suas inúmeras citações e referências bibliográficas. Dessa forma, o trabalho de Broca está muito mais próximo daquilo que Candido aponta:

(...) penso que é apenas tributo à elegância ensaística de uma exposição que quer ser o mais aliviada possível de qualquer exibicionismo. E também corresponde, com certeza, a um conhecimento tão antigo e arraigado, que já se desprendeu das múltiplas origens parciais e vale como sistematização pessoal. (CANDIDO, 1981, p.8)

É, todavia, na pesquisa de Décio de Almeida Prado que podemos verificar maior riqueza de detalhes sobre o episódio da segunda visita de Arago. O estudioso vale-se de um artigo publicado no Jornal do Commercio, Rio de Janeiro, assinado por alguém que se denomina Espectador. Numa de suas descrições, diz o cronista anônimo:

“A aparição do Sr. Jacques Arago no primeiro camarote da primeira ordem à direita da cena foi estrondosamente saudada: a esse estrondo seguiu-se um profundo silêncio, viva curiosidade se manifestou em todos os semblantes, os espectadores das cadeiras e plateia puseram-se de pé e descobriram-se apenas o venerando cego, visivelmente comovido, mostrou desejo de falar". (PRADO, 1972, p. 101)

Em seguida, Prado comenta e reproduz um trecho do discurso de Arago:

O pequeno discurso de Arago foi um modelo de diplomacia, afagando deliciosamente, ao terminar, a vaidade nacional: “J'avais cru jusqu'à ce jour que le

\footnotetext{
${ }^{56}$ Essa obra integra o acervo Brito Broca, do IEL-UNICAMP, doação da própria família do cronista.
} 
coeur ne pouvait avoir qu'un seul autel, qu'une seule patrie; je m'était trompé. Le coeur est citoyen de l'univers; et désormais je ne séparerai plus dans mes souvenirs la France du Brésil, Paris de Rio-Janeiro... Encore et toujours, merci” Não se poderia acalentar, com mais tato, o "bovarysmo" latente do público brasileiro. (PRADO, 1972, p.101-2)

Brito Broca observa em sua crônica que o discurso do dramaturgo havia sido reproduzido em francês por alguns jornais da época. Ele próprio também o faz em seu artigo, mas por meio do discurso indireto, em português:

(...) até o presente julgara que o coração não podia ter senão um único altar, uma só pátria; mas se enganava: o coração é cidadão do mundo: de ora em diante não separaria mais Paris do Rio de Janeiro. (BROCA, 1992, p.226)

Dessa forma, somos levados a pensar: teria Brito Broca se valido da mesma fonte que Décio de Almeida Prado para compor sua crônica? Ou teria simplesmente se atido a outra, visto que o próprio cronista comenta que outros jornais teriam publicado o discurso de agradecimento de Jacques Arago?

Essa mesma observação pode ser feita em relação ao episódio em que João Caetano é coroado no palco, logo após sua apresentação. Décio de Almeida Prado também registra a cena em seu estudo quando transcreve outro trecho do artigo do cronista do Jornal do Commercio, bem como fez Brito Broca:

"O grande gênio correu ao camarote de Jacques Arago e, com essa abnegação, própria de um nobre coração, com o desinteresse das almas grandes, com a franca satisfação dos gênios elevados, pediu licença para coroar o velho escritor, que, recusando cavalheirescamente essa homenagem devida ao seu talento criador, à fúlgida majestade de sua concepção, tirou apenas para si uma folha da coroa e, tateando, coroou o artista (...)" (PRADO, 1972, p.102)

O artigo de Silva Paranhos, é preciso lembrar, de certa forma também trata da segunda estada de Arago no Brasil. Comenta ele que, retornando à França ${ }^{57}$, o escritor teria composto um drama em homenagem a João Caetano como forma de agradecimento às honras recebidas e que inclusive a peça já havia sido duas vezes aplaudida em Paris. Chama a atenção, entretanto, o tom irônico do comentário de Paranhos:

Deus queira que o romancista não escrevesse com a mesma veracidade e consciência com que em um de suas histórias de viagem falou do nosso país. Entre outras provas de sua fértil imaginação citarei esta, que não reproduzirei talvez literalmente: "A cidade do Rio de Janeiro fica à beira de um extenso e pitoresco canal coberto pela abóbada natural que sobre ele formam os ramos das frondosas árvores que o bordam de uma e outra margem". (PARANHOS, 1953, p. 105)

\footnotetext{
${ }^{57}$ Jacques Arago, depois da apresentação de João Caetano, seguiu para a França na manhã do dia 19 de outubro de 1850 .
} 
De qualquer forma, podemos mais uma vez observar a confluência das informações de Brito Broca e de Décio de Almeida Prado. No estudo deste também encontramos as palavras de Arago a João Caetano, embora a fonte seja Voyage autour du monde sans la lettre A, do próprio dramaturgo francês. Assim, temos:

Jacques Arago publica em 1853 um livro, Voyage autour du Monde sans la Lettre A
- não confundir com Souvenir d'un Aveugle, Voyage autour du Monde, com várias
edições a partir de 1838 - no qual, para imensa satisfação de milhares de brasileiros,
faz uma referência carinhosa e entusiástica a João Caetano: "Oh! Que ne m'est-il
permis de vous citer ici un comédien d'élite que l'Europe serait fière de posséder,
qui ne s'est inspiré que de lui-même, et qui possède son Schiller, son Corneille, les
chefs d'oeuvres de nos poètes, et les interprète si dignement, que je vous porte le
défi de rester froid s'il vous ordonne de pleurer, de trembler, de frémir ! Cet homme
est une des gloires brésiliennes". (PRADO, 1972, p.103)

Em nota, Prado diz que essa citação foi recolhida por Moreira de Azevedo ${ }^{58}$ e repetida por quase todos os biógrafos de João Caetano. Conta também que Arago "referiu-se ainda ao ator brasileiro em algumas edições de Foyers et Coulisses, conforme assinala Lafayette Silva, comparando-o a Ligier" (PRADO, 1972, p.103). Esta última observação comprova as informações apresentadas por Brito Broca.

Outro ponto em comum na pesquisa desses dois estudiosos diz respeito à cena política da época. Logo de saída em sua crônica, Broca adverte seu leitor:

Muito teríamos que dizer desses folhetins estampados em 1851, no Jornal do Commercio, do que eles refletem a vida política, social e teatral da época. A literatura naquele tempo pouco preocupava os cronistas. No terreno artístico era apenas o teatro que lhe chamava a atenção. (BROCA, 1992, p.223)

O cronista parece aqui desculpar-se por não poder tratar de um acontecimento da vida literária do Brasil daqueles tempos. Realmente, como comprova Décio de Almeida Prado,

No século XIX os fatos teatrais, acompanhando os políticos, precipitam-se. As tropas de Napoleão invadem Portugal. A corte portuguesa busca refúgio no Brasil, logo está instalada no Rio de Janeiro. Em 1810 o príncipe regente, o futuro D. João VI, manifesta por meio de um decreto o seu desejo de que "nesta capital [...] se erija um teatro decente e proporcionado à população e ao maior grau de elevação e grandeza em que se acha pela minha residência nela (...)”. (PRADO, 1999, p.31)

As sucessivas construções de edifícios teatrais, como lembra Prado, refletem ainda a importância do gênero para a época. Segundo ele, cinco foram levantados no mesmo local até se chegar ao que hoje recebe o nome de Teatro João Caetano.

\footnotetext{
${ }^{58}$ Revista do Instituto Histórico e Geográfico (Tomo XXXIII, p. 345).
} 
Retomando a presença de Arago no Brasil, vamos agora acompanhar o último parágrafo da crônica que comporta sua terceira e última visita. Dessa vez, vinha ele acompanhado de sua sobrinha Hortense e hospedou-se na casa de João Caetano, "à rua do Lavradio, esquina de Senado", informa o cronista. Décio de Almeida Prado conta-nos ainda que Arago teria escrito ao ator brasileiro comunicando-lhe de sua visita: "Mon âme a froid sous le ciel de la France, je vais la rechauffer au soleil de ta patrie qui sourit toujours aux malheureux: le proscrit te demande ton foyer et l'hospitalité" (PRADO, 1972, p.103).

Ainda com base no artigo de Pires de Almeida, Broca conta que Jacques Arago foi acometido por uma apoplexia "depois de haver devorado forte e apetitosa maionese de robalo e camarão" (BROCA, 1992, p. 227) O teatrólogo falece então no dia 27 de novembro de 1854 na casa do amigo João Caetano. O ministro francês, segundo Prado, indagando sobre o estado de saúde de Arago obteve a seguinte resposta: "O escritor Jacques Arago acaba de falecer nos braços do primeiro ator dramático brasileiro" (PRADO, 1972, p.104).

Lafayette Silva complementa o fato quando relata em sua obra que:

\begin{abstract}
A 4 de dezembro, foi rezada missa por intenção de sua alma, mandada celebrar por João Caetano e Hortense Arago. Esta regressou à França a 1 de janeiro de 1855, pelo La Plata. Para acudir às necessidades da repartição de Hortense Arago, cedeu-lhe João Caetano um benefício, a 3 de dezembro, no São Pedro, com A gargalhada. (SILVA, 1936, p. 73)
\end{abstract}

Ele também nos relata que, dois dias antes de morrer, Jacques Arago havia composto os seguintes versos em homenagem a João Caetano:

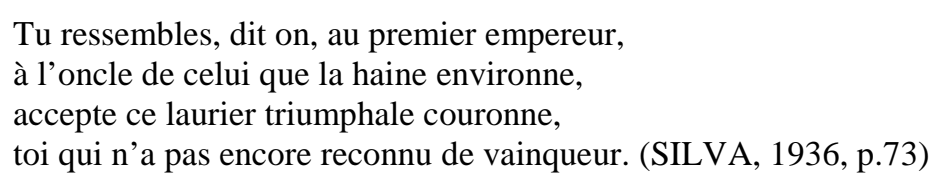

Com recorte mais preciso, o capítulo do livro de Décio de Almeida Prado nos traz outros detalhes das visitas de Jacques Arago ao Brasil. Entretanto, não podemos deixar de notar o grande poder de síntese no trabalho de Brito Broca uma vez que consegue nutrir e orientar sua pesquisa com informações bastante coerentes sobre o fato que investiga. Além disso, é preciso observar que os dois falam de posições e épocas distintas. Brito Broca era um jornalista que se dedicou intensamente aos estudos literários; afora isso, um autodidata que admirava tudo que envolvia a França numa época em que a influência desse país ainda era muito forte entre nós. Entretanto, o meio pelo qual seu trabalho veiculava não lhe garantia 
uma análise mais detalhada de determinados objetos, como é o caso da crônica sobre Arago no Brasil.

Em contrapartida, temos o estudo de Décio de Almeida Prado. Este representa a fala de um acadêmico e crítico teatral de grande importância para o país. Foi um dos intelectuais integrante do grupo de Clima $^{59}$, assim como Antonio Candido, Paulo Emílio Salles Gomes, Lourival Gomes Machado, então responsáveis fixos por seções específicas da revista, ficando o teatro, evidentemente, a cargo de Décio. Sua formação universitária, como observa Maria Silva Betti, "verifica-se precisamente durante a fase de atuação dos docentes franceses na Faculdade de Filosofia da Universidade de São Paulo, na década de 30” (BETTI, 1997, p.94); esse contato se ressente na "tendência ao aprofundamento analítico e na preocupação em suscitar sempre uma consciência clara do contexto e das características estéticas e filosóficas inerentes às diversas manifestações" (Ibidem, p.95). Seu trabalho de levantamento e análise do teatro nacional "representa, para a área de estudos teatrais no Brasil, o que o trabalho desenvolvido por Antonio Candido representa para a da literatura" (Ibidem, p.96). Destaca-se ainda sua atuação como professor na Escola de Arte Dramática, em 1948, a convite de Alfredo Mesquita; assim como, a partir de 1966, sua atividade na área de Literatura Brasileira da Faculdade de Filosofia, Letras e Ciências Humanas da USP, ministrando cursos que abordavam a evolução do teatro brasileiro, sobretudo nos séculos XIX e XX.

Dessa forma, faz-se notar que ambos, à sua maneira, conseguem por meio da intensa atividade de pesquisa transportar um fato tão remoto da história cultural do Brasil para a apreciação e o estudo dos leitores de hoje.

\footnotetext{
${ }^{59}$ Revista, criada em 1941 por Antonio Candido dentre outros, voltada para a produção intelectual em geral, sobretudo, a da cidade de São Paulo. Seu papel é significativo pois, com sua criação, ganhava corpo a transformação da crítica nacional que havia começado no movimento modernista e, sequencialmente, com a criação da Universidade de São Paulo, nos anos de 1930.
} 
Vauthier em Recife (1839)

A presença de Vauthier em duas crônicas de Brito Broca merece um destaque dentre os estrangeiros que estiveram no Brasil durante o século XIX. Tanto em "A lenda de Maciel Monteiro”, de 1949, quanto em “'Salões' e 'Salas' do Romantismo”, de 1958, ambas reunidas em Românticos, pré-românticos e ultra-românticos, Brito Broca nos da um significativo quadro de como eram os ambientes frequentados por vários escritores e intelectuais da metade do século XIX, ambientes estes que aspiravam ao modelo de vida europeu.

No primeiro artigo, como já nos é instruído de saída, Broca reporta-se à figura de Maciel Monteiro ${ }^{60}$, um "diletante por excelência". O cronista afirma que "seu tipo reproduzia muito bem o de nobres ancien régime, quando se pôde falar, em todo sentido da expressão, na delícia de viver". Conta ainda que, muito jovem, Maciel Monteiro partiu para Europa (1820), precisamente Paris, onde o deslumbramento causado pela urbe o levou a "assimilar um pouco apressadamente a civilização que o envolvia”. Segundo o cronista,

Quase nada se sabe de sua permanência em Paris, senão que se bacharelou em Ciências e Letras e se doutorou em Medicina. Pôde também assistir de perto à expansão do movimento romântico, mas que impressões isto lhe teria causado? Até que ponto participou da nova mentalidade que ali se formava? Se a sua poesia, aliás tão escassa, é romântica, seu espírito parece ter-se conservado de um homem do Século 18, contemporâneo de Rivarol e Chamfort. (BROCA, 1979, p.56)

Nas entrelinhas, lê-se que Maciel Monteiro, apesar de jovem e inclinado à poesia, não soube absorver de forma satisfatória à sua própria formação o clima de transformações pelo qual passava a França. Tampouco seus relatos parecem ser suficientes para que o cronista possa remontar algum acontecimento do escritor durante a estada em Paris, ocorrência que, segundo Broca, não se dará a Francisco do Rêgo Barros ${ }^{61}$, outro brasileiro que se encontrava na mesma época por lá. Vejamos como Broca revela esse fato a seus leitores:

\footnotetext{
${ }^{60}$ Antônio Peregrino Maciel Monteiro, segundo Barão de Itamaracá (Recife, 1804 - Portugal, 1868) foi médico, jornalista, diplomata, político, orador e poeta. Escritor de qualidade duvidosa, Maciel Monteiro encontrou espaço para também atuar na cena política de Pernambuco (primeiro como deputado provincial e depois como deputado geral, no Rio de Janeiro). Esse fato leva Veríssimo, citado por Brito Broca, a considerar: "A literatura não teria perdido grande coisa com o fato do Barão de Itamaracá haver sido absorvido pela política. E teria esta auferido grande vantagem com a aquisição?” (BROCA, 1979, p. 55)

${ }^{61}$ Francisco do Rêgo Barros (Cabo de Santo Agostinho, 1802 - Recife, 1870) ou conde da Boa Vista, foi militar e político. Sua carreira militar teve início aos quinze anos quando se alistou no Regimento de Artilharia de
} 
Quase na mesma ocasião, estudara na França outro pernambucano, Francisco do Rêgo Barros, futuro Barão e Conde de Boa Vista, que trouxe para o Recife o espírito requintado da Restauração, procurando emprestar à cidade uma feição europeia. (BROCA, 1979, p.56)

Desse segundo pode-se considerar que soube não somente apreender a atmosfera vivida na França, como também o quis trazer junto consigo tudo aquilo que lhe havia causado uma boa impressão. No caso de Francisco do Rêgo Barros, tanto a condição de presidente da província de Pernambuco quanto a necessidade de reforma de sua capital, a cidade de Recife, impulsionaram-no a encarar um projeto audacioso para a época, que consistia em uma mudança estrutural e, pode-se dizer até, mental daquela sociedade.

É exatamente nesse ponto que surge o nome de Louis Léger Vauthier (1815 - 1901), o engenheiro responsável por muitas das transformações ocorridas na capital pernambucana. Segundo Brito Broca, Francisco do Rêgo Barros

Contratou arquitetos estrangeiros para embelezá-la [a cidade de Recife], dentre os quais o francês Vauthier, de cuja influência civilizadora nos dá conta Gilberto Freyre no volume Um Engenheiro Francês no Brasil. (...) Presidente da Província, Boa Vista mandara construir um belo palácio para sede do governo e procurava modelar o Teatro Santa Isabel pelos melhores de Paris. A par disso, abria os salões aos amigos, em noitadas de elegância e mundanismo, que reviviam naquele recanto de província o refinamento parisiense. (BROCA, 1979, p.56)

A segunda crônica, “Salões' e 'Salas' do Romantismo”, traz um pequeno apanhado desses locais muitas vezes transformados em verdadeiros pontos de encontro entre escritores e intelectuais de diversas partes do país; "alguns de caráter essencialmente mundano, com grande pompa e luxo; outros mais modestos; todos refletindo, porém, a influência europeia" (BROCA, 1979, p.80). Todos aqueles que eram dados à vida mundana frequentavam algum salão, fosse ele na corte, fosse ele na província. E é com a intenção de indicar-lhe como um dos responsáveis por esses ambientes que Brito Broca evoca mais uma vez o nome de Francisco do Rêgo Barros. Vejamos de que maneira:

Em 1830, em Recife, surge a estrela de Francisco do Rêgo Barros, Conde de Boa Vista, que ali exerceu uma ação essencialmente civilizadora até 1844, mais ou menos. Depois do fracasso da revolução de 1817, a vida intelectual em Pernambuco começara a atravessar uma situação de crise. Contra isso reagiu Rêgo Barros, ao

Recife. Seu envolvimento na Revolução de Goiana rendeu-lhe exílio em Portugal, lugar em que permaneceu até 1823. Em liberdade, foi para Paris onde bacharelou-se em Matemática. Ao retornar ao Brasil, dedicou-se à política, sendo designado presidente da província de Pernambuco (1837 - 1844). 
regressar da França, onde se diplomara e se deixara impregnar pelos hábitos e costumes da Restauração. Contratou arquitetos estrangeiros para embelezar Recife, entre os quais o engenheiro francês Vauthier. Seu propósito era criar na cidade condições de conforto, bem-estar e civilização que impedissem os pernambucanos de emigrar. (BROCA, 1979, p.80)

A crônica prosseguirá, portanto, traçando o perfil dos frequentadores dos salões espalhados pelo país. Brito Broca retomará a figura de Maciel Monteiro, assíduo frequentador dos salões do Conde de Boa Vista (uma vez ainda em Recife) e, mais tarde na capital do império, dos salões do Marquês de Abrantes, em Botafogo; outros dois são os salões de Nabuco de Araújo e do Barão de Cotegipe. Segundo Broca,

Ao primeiro comparecia frequentemente José de Alencar, que vivia a "arrastar a
asa" a uma filha de Nogueira da Gama. E como esta preferisse os brasões de um
nobre português à glória literária de um "moço pobre", o escritor teria revelado o seu
ressentimento em vários trechos da Diva e sobretudo no enredo de Senhora (...) No
palacete de Cotegipe brilhava a elegância discreta de Alfredo d'Escragnolle Taunay
e Artur de Carvalho Moreira. Brasílio Itiberê da Cunha e Cardoso de Meneses
(futuro Barão de Paranapiacaba) faziam música; Ciro de Azevedo e o Barão da Vila
da Barra diziam versos. (BROCA, 1979, p.81)

Os "salões", lembra Broca, eram diferentes das "salas". Estas configuravam pequenos encontros feitos em casa mesmo, entre os amigos mais próximos, sem luxo, "reuniões que se caracterizavam acima de tudo pelo "brasileirismo"” (Ibidem), relata o cronista, segundo uma definição de França Júnior, publicada em um folhetim de 1867.

Como se pode perceber até aqui, os dois artigos não chegam a mencionar, de forma direta, qualquer tipo de relação existente entre Vauthier e os brasileiros. Broca aponta somente sua presença como sendo responsável pelo processo de transfiguração da capital pernambucana. Entretanto, sua permanência no Brasil marca em certa medida a influência da cultura francesa entre nós, sobretudo se tomarmos em consideração as palavras do próprio Brito Broca ao apontar sua "influência civilizadora", quando lembra Gilberto Freyre. Esta referência, portanto, nos permitirá interpretar um pouco da relação entre o espaço constituído a partir de um modelo europeu dentro do qual se identificava a burguesia brasileira já na primeira metade do século XIX, e que nele via uma espécie de transferência do meio civilizado, em especial o da França, a que tantos aspiravam em terras brasileiras. Outrossim, não podemos deixar passar em branco essa indicação bibliográfica do cronista que em outros textos lhe é tão cobrada. 
Um Engenheiro Francês no Brasil, portanto, nos servirá como resposta a quem teria sido esse profissional e de que maneira sua influência operou sobre a mentalidade da província de Pernambuco. A obra, como se pode depreender, consiste em um estudo de caráter sociológico cuja investigação sobre a influência francesa no Brasil leva em conta a atuação de "agentes técnicos" aqui instalados para promover as inovações que urgiam na cidade de Recife e as relações travadas entre esses técnicos e os brasileiros que presenciaram tal acontecimento. O ensaio de Gilberto Freyre se ocupará, portanto, das relações entre Brasil e França fora "da rotina acadêmica ou da cadência diplomática"; partirá das relações estabelecidas entre a "multidão de pequenos técnicos, comerciantes, pasteleiros, hoteleiros, professores de esgrima, cozinheiros, modistas, alfaiates, padeiros, daguerreotipistas, boticários, parteiras, artesãos franceses" que exerceram "considerável influência sobre a vida brasileira do século XIX” (FREYRE, 1960, p.39-40).

Tomando como ponto de partida a invasão holandesa, que segundo o autor "revolucionou a paisagem e alterou a vida, através das inovações de ideias e de técnicas", o sociólogo, na introdução feita à segunda edição de sua obra, aponta Recife como espécie de pólo no qual "desde 1630 começa a florescer uma cultura diferenciada da luso-Católica em traços essenciais" (Ibidem, p.41). Gilberto Freyre faz aqui uma referência direta à instalação, em solo pernambucano, dos primeiros protestantes europeus (incluindo aí os franceses) e de judeus sefardins, vindos da Holanda. Dessa forma, para o sociólogo,

(...) é fácil de explicar o cosmopolitismo que não só desses dias, mas de época ainda mais remota, se esboça no Recife, onde culturas nórdicas ou norte-europeias, além da israelita, começam no próprio século XVI a salpicar de pequenas manchas de diferenciação a cultura dominante: a luso-Católica. (FREYRE, 1960, p.42)

Freyre explica que, dentre as várias culturas diferentes da dominante, a francesa, no caso de Pernambuco, já havia dado indícios de sua aparição em alguns momentos da história, chegando com isso a "inquietar agentes do Santo Ofício". Estes, por sua vez, estavam sempre atentos ao que "nessa cultura, então dividida em Católica e Protestante, fosse expressão ou aspecto calvinista ou huguenote: aspecto revolucionário ou herético, do ponto de vista lusoCatólico”. Em razão disso, o sociólogo considera:

É possível que desde então a palavra "francesia" tenha adquirido o ranço que por muito tempo haveria de guardar no Brasil, sugerindo heresia, novidade, esquisitice, requinte no trajo, nas maneiras, no amor. (FREYRE, 1960, p.42) 
Desse modo, Gilberto Freyre abre caminho para sua interpretação da influência francesa em Pernambuco, incitando haver desde outrora terreno propício para tal disseminação. O sociólogo, assim, toca em vários pontos da história em que se discute o papel da penetração dessa cultura no Brasil, responsável de certa forma pelo aparecimento de algumas das revoltas contra o Império centralizado, principalmente as pernambucanas, de 1817 e de 1824, até chegar a Revolta Praieira, em 1848,

(...) movimento brasileiro para o qual é evidente ter concorrido o engenheiro Vauthier, não direta ou intencionalmente, é claro - os Praieiros ortodoxos nunca foram seus apologistas e sempre o consideraram estrangeiro a serviço da oligarquia Rêgo Barros-Cavalcanti e de outros despotismos, para eles abomináveis, da época mas indiretamente: por ter aqui (como outrora os luteranos franceses, transculturados em Católicos, a que se referem as confissões do Santo Ofício) ideias sutilmente contrárias à ortodoxia ou à ordem social dominantes. (FREYRE, 1960, p.48)

Ideias que, segundo Freyre, relacionavam-se ao progresso técnico e ligavam-se a outras, de progresso social mas que, "triunfantes, importariam num tipo novo de sociedade e de cultura, em que os dirigentes seriam antes os sábios, os técnicos, os intelectuais, que os senhores de terras só pelo fato de serem senhores de terras; ou os ricos só por serem ricos" (Ibidem).

A investigação inicial do sociólogo converge para uma Recife em que a vinda de um técnico estrangeiro - juntamente com suas ideias inovadoras, oriundas "Daquela Meca, daquela Escola quase messiânica que era a Politécnica de Paris" -, era tida como algo quase natural àquela sociedade já habituada a se ver mais arredia do que as demais. O sociólogo parece abrir terreno para promover a sociedade pernambucana como a que, por conta da mentalidade de alguns de seus membros, já se encontrava, em certa medida, preparada para conviver com cabeças mais transgressoras, necessitando apenas de um pequeno empurrão para que as novas ideias logo fosse assimilada. O empurrão quem o daria seria Vauthier. Gilberto Freyre afirma que a atuação desse engenheiro teria sido de fato fundamental para a transformação da mentalidade social pernambucana, sobretudo, quando considera que a sua presença entre nós não foi apenas uma experiência de engenheiro ou de técnico, "foi também - repita-se - de socialista”. Para ele,

Vauthier foi um dos pioneiros da expansão de ideias socialistas francesas no Brasil, tendo evidentemente contribuído para que no Recife se aguçasse nos intelectuais e nos próprios políticos o espírito de renovação social da gente brasileira de acordo com sugestões socialistas pré-marxistas: sugestões que depois de terem dado alguma cor, que hoje denominaríamos trabalhista, a reivindicações aparentemente só 
políticas da chamada Revolução Praieira, permaneceram vivas nas ideias agitadas em artigos por Antônio Pedro de Figueiredo e manifestaram-se nas inquietações, também de publicista o seu tanto afrancesado, de Nascimento Feitosa e nas de economista, igualmente colorido por ideias francesas e teorias socialistas, que foi Aprígio Guimarães; e vieram dar, ao que parece, às preocupações abolicionistas de Joaquim Nabuco o tempero ou o sabor de preocupações de reforma social que as distinguem da retórica simplesmente política ou do romantismo apenas jurídico da época. (FREYRE, 1960, p.52)

Lembrando o caso da extinta União Soviética, Freyre observa, com base em alguns estudiosos da história dos movimentos sociais na Europa, que a chamada utopia falansteriana dos fourieristas seria o embrião da realidade soviética dos marxistas uma vez que aquela considerava o trabalho nos falanstérios "o mais belo dos desportes", ao passo que esta última nada mais seria do que a "aplicação das ideias de Fourier não a falanstérios mas a empresas industriais governadas por Estado ditatorial” (FREYRE, 1960, p.58).

Louis Léger Vauthier permaneceu no Brasil de 1839 a 1846. Os sete anos de convívio entre os brasileiros parecem ter sido suficientes para que difundisse o Fourierismo ${ }^{62}$, muito em voga na "França intelectual", principalmente entre ex-alunos da Politécnica de Paris, como era o seu caso. O que fica evidente a respeito de sua atuação em Recife é a condição propícia encontrada por um jovem engenheiro que, imbuído de conceitos tão adversos ao meio em que se viu inserido, não deixou de encontrar "gente familiarizada com ideias e autores novos, franceses e ingleses" (Ibidem, p.66) com quem pudesse estabelecer proximidade. Brasileiros "afrancesados" nas ideias, bem ao que sugere Gilberto Freyre em relação a este termo também usado para designar os "adeptos de ideias e gostos e entusiastas de técnica francesas mais de renovação do que clássicas" (Ibidem, p.112).

Uma vez contratado pelo governo de Rego de Barros com intuito de modernizar e higienizar a capital pernambucana, Vauthier e os técnicos que também vieram para o Brasil construíram estradas de rodagem e pontes que passaram a ligar a cidade às áreas produtoras de açúcar no interior, abriram canais, realizaram aterros, criaram um sistema de abastecimento

\footnotetext{
${ }^{62} \mathrm{O}$ termo deriva do nome do filósofo e economista francês Charles Fourier (1772 - 1837), considerado um dos teóricos do socialismo utópico do século XIX, o qual idealizou a criação de unidades de produção e consumo as falanges ou falanstérios - que organizariam a vida em comunidade por meio do cooperativismo integral e autossuficiente. Essas unidades de produção e moradia deveriam dedicar-se à produção agrícola e industrial local. Seu projeto pregava o fim da separação entre trabalho e lazer e a adaptação da educação às inclinações e habilidades de cada criança. Também preconizava que os bens fossem distribuídos de acordo com a necessidade de cada morador e que o sexo fosse liberado de restrições morais.
} 
de água potável; o engenheiro francês também foi responsável pela execução do projeto do Teatro Santa Isabel, obra em estilo neoclássico francês, representante da arquitetura da época.

Se Broca não explorou sua estada entre os brasileiros, há de se considerar dois fatores para o caso. O primeiro, talvez por supor que a obra de Gilberto Freyre desse conta de toda atuação de Vauthier junto à sociedade de Pernambuco, sendo portanto desnecessária sua contribuição ao assunto. O segundo fator leva-nos a acreditar que seu intuito dentro dessa crônica era mesmo o de mostrar ao leitor de que caráter se revestiam os ambientes desse período e, ao mesmo tempo, dar conta das figuras que neles marcavam presença, debatendo os mais variados assuntos, dentre os quais, possivelmente, ideias como as trazidas pelo engenheiro francês Vauthier. 
François Biard (1858) e o casal Agassiz (1865)

Pierre Rivas afirma que depois de 1870 "o progresso da navegação e o desenvolvimento do colonialismo alargam o horizonte literário para todo o planeta" (RIVAS, 1995, p.128). Novos cenários para a literatura exótica, como África, América Latina e Extremo Oriente, surgem para instigar um pouco mais a curiosidade dos escritores e dos leitores. Rivas destaca ainda que é dentro desse contexto que serão publicados em Le Tour $d u$ Monde ${ }^{63}$, em 1861, Voyage au Brésil - 1858-59, de François Biard e o também Voyage au Brésil, em 1868, do casal Agassiz.

Embora a referida obra de Biard não seja a mesma comentada por Broca ${ }^{64}$, é sobre esses visitantes que ele discorrerá em crônica de 12 de novembro de 1960 em A Gazeta, sob o título "Depoimentos de viajantes", posteriormente recolhida no volume Teatro das letras, em 1993. Vale lembrar que outro viajante, o inglês Richard Francis Burton, que esteve em terras mineiras no ano de 1868, também figurará neste artigo.

O mote do cronista é trazido por Gilberto Freyre que, segundo ele, já havia demonstrado "a importância que pode ter para a caracterização sociológica de um povo sua arte culinária” (BROCA, 1993, p.39). Partindo de tal afirmação, Broca tentará identificar, por meio dos depoimentos de viajantes estrangeiros, "os hábitos gastronômicos dos brasileiros".

Sem compreender exatamente qual critério norteia a seleção do cronista, o leitor terá diante de si uma pequena amostra de como eram os hábitos alimentícios dos brasileiros em meados do século XIX, compreendidos a partir da ótica de visitantes estrangeiros. O primeiro deles é o pintor francês François Biard que, segundo o Brito Broca, esteve no Brasil de 1858 a

\footnotetext{
${ }^{63}$ Le Tour de Monde é a continuação de Le Journal de Voyages, revista de caráter geográfico, publicada entre 1860 e 1894 ( $1^{\mathrm{a}}$ fase), com uma pausa durante a guerra franco-prussiana em 1871; seu retorno se dá em 1895 ( $2^{\mathrm{a}}$ fase) chegando até 1914. O periódico foi fundado por Edouard Chartron e abrigou grande número de iconografias.

${ }^{64}$ Brito Broca parece valer-se da tradução de 1945 realizada por Mario Sette a partir do original francês Deux années au Brésil, também editado pela Hachette, assim como Voyage au Brésil. Ao que tudo indica, trata-se de dois títulos para a mesma obra.
} 
1860. O segundo relato ficará por conta de Elizabeth Cary Agassiz que, juntamente com seu marido, permaneceu no país por um ano, de 1865 a 1866. Há ainda, como já vimos, outro viajante; este é Richard Francis Burton, cientista inglês que esteve em Minas Gerais no ano de 1868.

Traçado seu tema, Broca destaca que François-Auguste Biard (1799-1882) quando esteve entre nós apenas informou que "no mercado do Rio, abrigadas em barracas, as negras vendiam café e carne seca com feijão, 'prato habitual da gente pobre e frequentemente das classes mais finas"” (BROCA, 1993, p.39). O cronista reforça ainda que o livro de Biard, Dois anos no Brasil, escrito por ele ao regressar à França ${ }^{65}$, não teve uma repercussão muito boa entre nós. Pintor popular e grande viajante, as causas que o trouxeram ao Brasil são aparentemente desconhecidas ${ }^{66}$. É sabido, no entanto, que chegou a ser o pintor da família imperial de D. Pedro II, ofício que deixou de lado para seguir viagem rumo ao interior brasileiro, estendendo-se para as bandas do Espírito Santo e do Amazonas.

O livro de François Biard divide-se em dez capítulos: um dedicado ao Rio de Janeiro, dois ao Espírito Santo e cinco sobre o Amazonas (os outros dois referem-se à travessia e ao retorno do pintor). A julgar pelo tom coloquial empregado no início da obra, em que o autor reproduz as falas dos "que aconselham na partida e indagam no regresso" (BIARD, 1945, p.5), vê-se que o tratamento dado à narrativa parece seguir por um caminho mais leve - como o é neste momento -, mas ora também perpassando uma vertente mais exagerada, quase humorística, como no fragmento em que o pintor descreve seu asco pelas instalações de uma hospedaria onde se encontrava antes de se encaminhar, após indicação do imperador, para um apartamento no paço da cidade (Ibidem, p.29).

É curioso notar como os relatos contidos na obra do francês não tenham despertado a atenção de Brito Broca visto que estes se revestem constantemente do caráter pitoresco que tantas vezes foram convertidos em assunto de suas crônicas. Dessa forma, faz-se oportuno observar que sua busca está voltada para as ilustrações de que o tema de seu artigo carecia, o

\footnotetext{
${ }^{65}$ Em 1861 foi publicada primeiramente uma breve relação de sua viagem na já referida Le Tour du Monde. A versão completa, ilustrada com 180 gravuras, apareceria em 1862, sob o título Deux années au Brésil.

${ }^{66}$ Cumpre saber na verdade que Biard, segundo ele próprio afirma em seu livro, encontrou dois motivos para sua viagem ao Brasil. O primeiro, confessa, se deve em razão de seu ateliê em Paris ter sido alvo dos planos urbanísticos do prefeito Haussman e suas estratégias político-militares. Desprovido de teto, Biard é tomado de grande tristeza. O segundo motivo que impulsionou sua vinda para cá é fruto de uma conversa que teve com um general belga que havia residido durante um longo tempo na Bahia. Este o convenceu de que uma estada no Brasil lhe faria bem à saúde e o ajudaria a esquecer os aborrecimentos.
} 
que não lhe permitiu naquele momento deixar-se ludibriar por outros pormenores. Abaixo, acompanharemos o trecho da obra de Biard em que se encontra o recorte feito por nosso cronista para que possamos observar melhor tal questão:

Nos intervalos do meu trabalho eu continuava a observar os costumes da terra. Ia
todos os dias ao mercado. É ali que melhor se apreciam os usos de um povo... Todas
as manhãs embarcações trazem das ilhas próximas laranjas, bananas, lenha, peixes; é
um espetáculo divertido no qual tomam parte os negros a gritar, chamar, rir ou
chorar. E como esses barcos não podem se aproximar do cais por causa de uma
rampa de pedra que desce até o mar, outros pretos, munidos de balaio redondo,
entram n'água e por vezes formam fila para se despacharem mais depressa. Quando
é alta a maré, aumenta o pagode costumeiro; caem mercadorias dentro d'água e os
escravos recebem como castigo socos e pauladas. Nas vizinhanças, abrigadas em
barracas, negras vendem café e carne seca com feijão, prato habitual da gente pobre
e frequentemente das classes mais finas. (BIARD, 1945, p,43)

Como se pode notar, somente neste pequeno trecho existem outros temas que poderiam tomar vultuosidade maior se o cronista assim o quisesse. No entanto, seu recorte inicial se mantém. E ele tocará seu artigo tão logo relate a impressão do pintor francês, não se importando em dar ao menos qualquer nuance do modo como Biard descrevia o Brasil e os brasileiros desse período mediante sua ótica estrangeira, como podemos notar no excerto acima. Nem mesmo o mercado da cidade do Rio de Janeiro - exatamente o local onde Biard verificara um dos costumes gastronômicos de nosso povo - fará com que Broca desvie seu caminho.

A questão da sistematicidade, algumas vezes já apontadas como falha no trabalho de Brito Broca, receberia bons argumentos em sua defesa se tomássemos esta crônica como uma referência ao tema.

Sem mudar o foco de sua investigação, a crônica seguirá num segundo momento para outro relato feito a partir das observações dos hábitos alimentares do brasileiro. É oportuno notar, no entanto, que as contribuições de Biard, mediante a leitura do cronista, parecem resumir-se àquela pequena ocorrência observada no mercado carioca, o que justificaria a rápida mudança para o relato de outros visitantes estrangeiros. 
A rápida passagem de Biard para os $\operatorname{Agassiz}^{67}$ se justifica, portanto, em razão destes, mais precisamente a mulher, serem mais minuciosos, como afirma o cronista. O livro de que se vale o cronista intitula-se Viagem ao Brasil - 1865-1866. O volume, que totaliza quinze capítulos, embora possua inicialmente caráter científico, aborda o Brasil sob diversos aspectos em razão das impressões pessoais que persistem durante a obra. Exemplos disso são as passagens em que Elizabeth Agassiz discorre sobre altivez de algumas escravas negras que vira no mercado do Rio de Janeiro, oriundas da Província de Mina, na África Ocidental; além, evidentemente, do destaque que dá a alguns dos hábitos gastronômicos dos brasileiros, como podemos verificar neste:

(...) a todo instante, na beira da estrada, um grupo de trabalhadores, suspendendo o trabalho, prepara o seu almoço; marmitas são penduradas em cima do fogo, a cafeteira chia sobre as brasas, e os homens, descansando em diferentes atitudes, fazem pensar num acampamento de boêmios. (AGASSIZ; AGASSIZ, 1975, p.62)

Uma vez consultada a obra dos Agassiz, não é difícil para o leitor perceber que capítulo Brito Broca toma como base em seu artigo. Trata-se do que relata o trajeto feito de Petrópolis a Juiz de Fora. Travando um diálogo com seu leitor, a cientista dará seu depoimento a respeito de como os hábitos alimentares das pessoas sempre lhe chamaram a atenção e que, por este motivo, relataria em seu livro os nossos. Vejamos:

\begin{abstract}
Não sei o que pensarão disso os meus leitores; mas, de minha parte, nunca leio uma narração de viagem sem que me sinta desapontada quando, após acompanhar fielmente o viajante, partilhando de todas as suas fadigas, ele me deixa para saciar a sua fome, sem me convidar para os prazeres de sua mesa. Farei, portanto, como desejaria que me fizessem; transcreverei o nosso "menu" e aproveitarei a ocasião para dizer uma palavra sobre os hábitos gastronômicos dos brasileiros. (AGASSIZ; AGASSIZ, 1975, p.62)
\end{abstract}

É a partir deste ponto que Brito Broca irá reproduzir em sua crônica as palavras de Elizabeth Agassiz, mostrando a seus leitores a visão que tinham os estrangeiros sobre alguns costumes adotados aqui quando o assunto era comida.

Brito Broca também aproveitará esta última leitura para comparar a visão da Sra. Agassiz à de François Biard. Segundo o cronista, ambos atentaram-se ao fato de que no Brasil

\footnotetext{
${ }^{67}$ O homem, o suíço Louis Agassiz (1807-1873), era botânico e geólogo; chefiou a expedição científica norteamericana que aqui esteve entre 1865-1866. Durante sua visita, cuidou de examinar e classificar muito da fauna ictiológica do país. A mulher, a cientista norte-americana Elizabeth Cary Agassiz (1822-1907), era a responsável pelos registros diários que mais tarde foram efetivamente publicados.
} 
o feijão era "prato fundamental em todas as refeições brasileiras". Vejamos como isso se procede na leitura da cientista:

Não há casa por mais pobre que não tenha a sua feijoada, nem há por mais rica que exclua de sua mesa esse prato por excelência, pelo qual as pessoas de todas as classes manifestam um gosto igualmente pronunciado. (AGASSIZ; AGASSIZ, 1975, p.62)

Diante de tais palavras, o cronista compara: "Como se vê, nesse ponto o testemunho de Elizabeth Agassiz coincide perfeitamente com o do pintor Biard" (BROCA, 1993, p.40). E aqui teríamos, portanto, o olhar do cronista que está "ao mesmo tempo sugerindo, desvendando e analisando" (CANDIDO, 1981, p.7).

A crônica prossegue com a visita do cientista inglês Richard Francis Burton ${ }^{68}$ que chegara a percorrer um dos caminhos feito pelo casal Agassiz. O trajeto de Petrópolis a Juiz de Fora serviu para relatar a presença de vários animais que encontrara no caminho, sobretudo os carneiros, "muito diversos dos merinos, magros, sujos e chifrudos, justificavam o preconceito popular contra eles" (BROCA, 1993, p.40-1). Burton, segundo Broca, considerou diversos depoimentos de outros estrangeiros que visitaram o Brasil com o intuito de elucidar a questão do preconceito de se comer carneiro. Assim, temos:

Luccok dizia que o carneiro tinha pouca procura no Brasil, alegando certas pessoas (talvez por gracejo) não serem alimento próprio para o cristão, uma vez que fora um cordeiro que tirara os pecados do mundo. Saint-Hilaire tinha dúvidas sobre essa afirmativa, considerando o pouco interesse culinário pelo carneiro por tratar-se de um alimento pobre nas zonas quentes do Brasil. Walsh, porém, confirmava a existência do preconceito popular contra os lanígeros, lembrando que ele existia também em Nápoles. O mesmo registrava Mawe. (BROCA, 1993, p.41)

Broca destaca para os leitores que a conclusão a que o estrangeiro chega é de que no Brasil, "em regra os preconceitos em matéria de alimentação eram extraordinariamente fortes e a culinária muito atrasada" (BROCA, 1993, p.41). Ao que parece, a história de preconceito ou não a esse tipo de carne ficará, promete Burton, para o segundo volume de seu livro, o qual o cronista afirma não ter conhecimento até a data.

\footnotetext{
${ }^{68}$ Richard Francis Burton foi um dos maiores viajantes ingleses do século XIX. Em 1865, foi nomeado cônsul britânico em Santos e, em 1867, conseguiu permissão para uma viagem pelo Brasil, que durou cinco meses. Visitou o Rio de Janeiro, Minas Gerais, Paulo Afonso, na Bahia, indo até Penedo, em Alagoas, seguindo pelo rio São Francisco, que denominou de "Mississipi brasileiro". Suas observações foram registradas no livro, Explorations of the highlands of the Brazil, publicado em Londres, em 1869 e traduzido para o português com o título Viagens aos planaltos do Brasil (1941).
} 
Vale ainda destacar nessa crônica um artifício muito utilizado em textos jornalísticos, que é o "nariz de cera". Trata-se de um termo já não muito usado ${ }^{69}$ para designar uma introdução vaga (às vezes até desnecessária) a uma notícia.

No caso de Brito Broca, é possível verificar esse recurso quando o cronista procura introduzir determinado assunto e para isso apoia-se em algum fato aparentemente sem relação direta com aquilo que pretende discutir. A diferença, talvez, - e por isso não podemos dizer que seu "nariz de cera" seja desnecessário - é que Broca na maioria das vezes procura abordar alguma ocorrência dentro do universo da própria literatura (a publicação de uma obra, a amizade entre escritores, um livro sobre o balcão de uma livraria etc.) para que consiga injetar o verdadeiro assunto de seu artigo. Nesse sentido, embora não se trate de algo relacionado diretamente à literatura, podemos pensar que a afirmação de Gilberto Freyre exposta no início da crônica cumpre o papel de nariz de cera em "Depoimentos de viajantes", uma vez que por meio dela Broca pôde relatar a visão desses estrangeiros sobre a "arte culinária" dos brasileiros daquele período.

${ }^{69} \mathrm{O}$ Manual de Redação e Estilo de $O$ Estado de S. Paulo indica o termo lead para esse tipo de técnica. 


\section{O Conde de Gobineau (1869)}

Tido como um dos mais importantes teóricos do racismo no século XIX, o francês Joseph-Arthur de Gobineau $^{70}$ - poeta, escultor, romancista e diplomata - é tema de crônica datada de 1950/1951, intitulada "Gobineau: convicções e ojerizas ou Arthur-Joseph no 'Deserto' do Novo Mundo",71. Trata-se de um artigo recolhido em Românticos, préromânticos, ultra-românticos, cujo interesse do cronista pelo tema, diferentemente de outras crônicas em que são vistos de modo mais claro quais são seus objetivos, aqui não se encontra tão evidente, ainda que o assunto pareça bastante pertinente aos estudos das relações culturais Brasil-França.

Os primeiros passos do cronista consistem na apresentação do Conde de Gobineau a seus leitores, mostrando-lhes os principais traços de sua obra e de seu pensamento. À medida que adentramos o artigo, mais nos damos conta da personalidade polêmica desse homem e de sua estranha relação com o Brasil (ou seria melhor dizer falta de relação?), fatos que por si só já justificariam qualquer pretexto para relatar sua presença entre nós.

Nessa crônica, as fontes de pesquisa de Brito Broca parecem estar mais evidentes ao leitor, uma vez que são apontadas tanto no corpo do texto quanto nas notas de rodapé que, embora não se saiba precisar se foram ou não inseridas por ele mesmo, trazem os nomes dos autores e suas respectivas obras de forma mais completa do que o habitual. Tratam-se, à primeira vista, das obras: À sombra da estante (1947), de Augusto Meyer; Morceaux choisis (1937), do próprio Gobineau; um artigo de Enrique Mendez Calzada, publicado no La

\footnotetext{
${ }^{70}$ Ville-d'Avray, 14 de julho de 1816 - Turim, 13 de outubro de 1882. De família comum, de poucas posses, Gobineau foi funcionário público chegando a exercer a função de secretário do escritor Alexis de Tocqueville, em 1835. Em 1849 tornou-se diplomata, atuando em Berna, Hanover, Frankfurt, Teerã, Rio de Janeiro e Estocolmo. Em sua principal obra, Ensaio sobre a desigualdade das raças humanas, de 1855, afirmava que a mistura de raças (miscigenação) era inevitável e que levaria a raça humana a graus sempre maiores de degenerescência física e intelectual.

${ }^{71}$ Brito Broca viria a se ocupar mais uma vez do escritor numa crônica reunida em Letras Francesas, de 1969, cujo título é "A volta de Gobineau".
} 
Nación, Buenos Aires (sem data); e Dom Pedro II e o Conde de Gobineau (1938), de Georges Raeders $^{72}$.

Isso posto, ainda não fica claro ao leitor qual teria sido a obra de maior referência para o cronista, visto que no percurso de seu texto não se vê nenhuma atitude no sentido de identificar com precisão em qual estudioso ele teria se baseado. Nossa hipótese aceita tanto a ideia de que ele teria feito uma mescla dessas referências ou mesmo se atido a alguma outra informação, não expressa no texto. Por esse motivo, a leitura dessa crônica será concomitante a outra obra de um estudioso que também se interessou pela estada do Conde de Gobineau em terras brasileiras e que, como já observado, também figura entre os autores consultados por Broca. Trata-se de Georges Raeders e sua obra O Conde de Gobineau no Brasil ${ }^{73}$.

Estabelecer conjecturas a respeito do tecido desse texto, no entanto, não garantirá resultado algum se antes não for feita sua leitura, verificando de perto como se dão suas amarras.

Dessa forma, quando se aproxima desse artigo e lhe observa a estrutura, conclui-se que o cronista mantém-se fiel à sua metodologia. É, portanto, sempre imbuído de sua prática de localizar seus leitores no tempo, que ele aqui usará, como meio de ilustrar o contexto histórico vivido no Brasil no momento da chegada de Gobineau, os episódios finais da Guerra do Paraguai, em 1869. Na sequência, operando sempre uma força de síntese, na qual busca informar seus leitores com elementos essenciais para compreensão do tema em debate, ele parte para uma pequena apresentação do diplomata francês enviado ao Brasil:

Escritor de grandes qualidades, já era então autor de uma obra que ia ter larga repercussão no futuro: Essai sur l'Inegalité des Races Humaines. Apesar disso, vinha fazendo carreira difícil, tanto na literatura como na diplomacia. Com vários livros publicados, entre os quais alguns de indiscutível mérito, não tinha conseguido interessar suficientemente o público e a crítica: enquanto como diplomata jamais interessara o governo, que preferia enviá-lo para pontos distantes do globo. Já estivera na Ásia. Agora vinha para a América do Sul. (BROCA, 1979, p. 311)

Georges Raeders, em $O$ Conde de Gobineau no Brasil, conta que o diplomata se achava na Grécia no momento de sua nomeação e que aguardava na verdade ser nomeado

\footnotetext{
${ }^{72}$ Com exceção do artigo de Enrique Mendez Calzada, as outras referências fazem parte do acervo do cronista, disponível na biblioteca do IEL-UNICAMP. Os dados completos de cada uma delas encontram-se no índice bibliográfico.

${ }^{73}$ Esta obra também aparece no acervo de Brito Broca, motivo pelo qual se tomou a liberdade de consultá-la para esse estudo. Ver referências bibliográficas.
} 
ministro da França em Constantinopla. Em 31 de maio de 1868, o francês teria escrito à irmã informando-a de que iria fazer de tudo para evitar o novo posto, pois não poderia levar a mulher e a filha mais nova.

Em sua crônica, Brito Broca reforça a ideia de que o francês teria empregado

(...) todos os esforços no sentido de evitar essa nomeação, mas fora impossível; tinha que submeter-se ao castigo, pois outra coisa não era senão um castigo a permanência numa terra semi-bárbara, de clima tropical, onde estaria continuamente constrangido, no mínimo, pelo espantalho da febre amarela. (BROCA, 1979, p.311)

Raeders comenta ainda uma última tentativa de Gobineau, em Paris, de tentar trocar de posto, e cita também o problema da febre amarela, "cujo primeiro caso ocorrera no Rio de Janeiro em 27 de setembro, [e que] grassava terrivelmente no Brasil, apesar das providências tomadas para sustar sua propagação" (RAEDERS, 1996, p.11). Observa-se aqui, portanto, uma confluência de informações entre Broca e Raeders.

A questão de grande relevância trazida pela presença de Gobineau no Brasil refere-se, evidentemente, ao choque de cultura sofrido pelo diplomata, sobretudo quando se considera o fato de que ele acabava de emergir do convívio com povos de longas tradições para inserir-se em outro ambiente, cujas referências não lhe era confortáveis.

Broca, como se depreende a seguir, é mais incisivo para descrever a questão:

Se na Ásia também sofrera as consequências de climas inóspitos, se também correra riscos e perigos, lá encontrara as remanescências de civilizações de civilizações milenárias a excitar-lhe a curiosidade. Na América do Sul, explicavelmente, não pressentia nenhum motivo de interesse. Faltava o passado, faltava história à terra. Assim, ao avistar a baía de Guanabara, o anfiteatro de montanhas que a circunda, o diplomata francês recusa-se a emocionar-se, como se emocionara em Constantinopla, porque não vê na natureza do Brasil o reflexo do valor humano, que dá à paisagem do Bósforo um lustre maravilhoso. (BROCA, 1979, p.311)

É exatamente após esse trecho que Broca afirma ter lido "numa página admirável” de Augusto Meyer $^{74}$ uma crítica à atitude do Conde de Gobineau, o qual acreditava que nosso país não possuía nenhuma tradição que fosse digna de ser admirada. Verifiquemos, então, a posição de Meyer a esse respeito:

\footnotetext{
${ }^{74}$ As considerações de Meyer encontram-se no capítulo "Gobineau e a paisagem inédita” (p.163-171), de $A$ sombra da estante.
} 
Não há paisagem que não deite raiz no passado e não respire de algum modo história. Às vezes, só história geológica, se quiserem, quando campeia em plena força a natureza virgem. Mas o tempo e a memória dos homens impregnam quase sempre as coisas de uma névoa de passado e evocação que as transfigura com não sei que toques de magia. Torna-se transparente qualquer paisagem, aos olhos de quem recorda ou tenta constituir os seus aspectos anteriores. E um país, uma cidade, uma rua, começa a desandar para as suas feições primitivas, a desmanchar-se, recompondo-se noutra ordem de planos, quando se projeta no seu passado a luz da fantasia histórica. (MEYER, 1947, p.163-64)

$\mathrm{Na}$ sequência, o cronista tece uma série de questionamentos que fazem coro aos apontados por Augusto Meyer. Começa lembrando o escritor Eça de Queirós:

(...) o homem, como observava Eça de Queirós constitui a maior curiosidade do mundo e, qualquer paisagem, urbana ou rural, o mais belo trecho da natureza, só será realmente interessante, quando a ele se liga o drama da vida humana. Estaria a terra brasileira assim tão destituída de "humanidade"? Nada exprimiria ela, nenhuma descoberta oferecia ao europeu hipercivilizado que vinha da França? (BROCA, 1979, p.311-2)

O tom de crítica à postura de Gobineau prossegue em todo o parágrafo. Broca acredita que o exagero do diplomata "hipercivilizado" residia justamente no fato dele "não tomar conhecimento das nossas origens", julgando possivelmente "encontrar-se numa terra meio selvagem, sem tradições, sem heranças", desconsiderando até mesmo o fato de "que a América é a própria continuação do Velho Mundo". Segundo o cronista, Gobineau "vê o homem americano como expressão de uma sub-humanidade, sem valorização histórica e sociológica". Conclui ainda que

Em tais condições, era natural acabasse por sentir-se num deserto e começasse a bocejar de tédio. O deserto ele o trazia consigo não só pelo estado de espírito desfavorável e a consequente neurastenia em que para aqui veio, como pelo absurdo das teorias raciais que lhe embotavam a capacidade de abnegação e análise. (BROCA, 1979, p.312)

Tais considerações nos levam a crer que Brito Broca se vê bastante influenciado pelas palavras de Augusto Meyer que, referindo-se à postura de Gobineau, diz:

Na observação de Gobineau acha-se representada tipicamente a atitude do europeu diante das "terras virgens", que ele, saturado de erudição, supõe vazias de sentido humano, por força de um conceito relativo, nem sempre justo. São "paisagens inéditas", dizia, concentrando no adjetivo o desdém. E, pensando em Constantinopla, ao contemplar a nossa baía, acrescentava: "Qu"est-ce que le plus achevé des paysages anonymes et muets en face d'un spetacle si parlant?" No imenso deserto, só enxergou o Imperador. (MEYER, 1947, p.164-65)

Observe-se que nos dois trechos acima tanto Broca quanto Meyer utilizam a palavra “deserto" para caracterizar o estado de espírito em que Gobineau dizia se encontrar quando estava no Brasil. Há ainda de se observar que as expressões "bocejar de tédio" e "terras 
virgens" "vazias de sentido humano" guardam entre si certa relação de sentido, uma vez que poderiam ser interpretadas como alguém que se "entedia" por estar diante de um "marasmo total". Sendo assim, vale afirmar que o posicionamento adotado por ambos parece confluir para uma proximidade de discursos em que um e outro ora valem-se da mesma palavra para se exprimirem ora valem-se de expressões que se complementam.

Depois de concluir que "a ilha" onde o escritor francês se confinou não era mais do que o fruto de seu voluntário distanciamento do meio em que passou a viver, nota-se que Brito Broca pede licença para expor algumas palavras "sobre o racismo de Gobineau". Deste ponto em diante, o cronista fará um resumo, tocando nos pontos-chave que norteiam a obra maior do diplomata, Essai sur l'Inegalité des Races Humaines, estudo nascido em 1853, e que, "embora provocasse algumas discussões, como uma polêmica com Tocqueville, não teve grande repercussão na época" (Ibidem).

Segundo Brito Broca, "a obra de Gobineau veio oferecer engenhosa estruturação ao racismo de Hitler". A teoria do escritor tomava como base a valorização dos fatores raciais: "É pela elevação da raça que os povos atingem um alto grau de civilização; pela degenerescência étnica, que entram em decadência e morrem”.

Para Gobineau, a raça branca, composta pelos camitas, semitas e arianos, era superior a duas outras: a negra e a amarela. Entretanto, "os camitas, fundindo-se com os negros, em lugar de dominá-los, produziram aglomerados sociais precários" e os semitas, "misturando-se com os camitas deram em resultado sociedades frágeis: assírios, fenícios". Sobram, portanto, os arianos que a princípio mantiveram sua pureza e "souberam construir as grandes civilizações". Entretanto, "as miscigenações com o preto e o amarelo tornaram-se inevitáveis, inoculando fermentos degenerativos". Dessa forma, "Os germanos, porque se defenderam de tais misturas, tornaram-se fortes e poderosos e Gobineau antevê-lhes um grande futuro".

Essas afirmativas levam o cronista a considerar que a teoria racista de Gobineau, além de tudo, ainda "repele (...) a organização democrática", uma vez que sempre quando uma raça tida como inferior subir na escala social, "estabelecer-se-á fusão dos diferentes elementos raciais", ocasionando a corrupção das elites, sua degeneração, decadência e morte. 
Tal concepção pode ser melhor ilustrada quando se verifica uma passagem do livro de Raeders, mais precisamente o décimo capítulo de sua obra em que reproduz um trecho de umas das cartas de Gobineau a um de seus conterrâneos. Nele, lemos:

\begin{abstract}
"Nenhum brasileiro é de sangue puro; as combinações dos casamentos entre brancos, indígenas e negros multiplicaram-se a tal ponto que os matizes da carnação são inúmeros, e tudo isso produziu, nas classes baixas e nas altas, uma degenerescência do mais triste aspecto" (...)

“As melhores famílias têm cruzamentos com negros e índios. Estes produzem criaturas particularmente repugnantes, de um vermelho acobreado... A imperatriz tem três damas de honra: uma marrom, outra chocolate-claro e a terceira, violeta". (RAEDERS, 1996, p.39-40)
\end{abstract}

A esse respeito, é bastante oportuno verificarmos ainda a passagem em que o próprio Raeders comenta a postura de Gobineau. Vejamos:

É aí que o autor do Ensaio demonstra não apenas uma prevenção sistemática do filósofo que se obstina, apesar de todos os desmentidos da realidade, em apoiar a mais contestável doutrina que forjou, mas, mais que isso, o ódio de um homem intratável que não hesita em incorporar à concepção geral do universo seus pequenos problemas pessoais. (RAEDERS, 1996, p.39)

Por concorrer a essa consideração, podemos juntar outra, proposta agora por Brito Broca, no momento em que também rebate o pensamento de Gobineau, alegando que a Sociologia moderna já havia posto tal ideia por terra - muito embora os alemães a tivessem tomado durante o Nazismo. Conclui, portanto, que:

Está provado não haver mais raça ariana pura, mesmo em estado de relativa pureza, e serem as condições sociais as determinantes do progresso e da decadência dos povos, nunca os motivos étnicos. (BROCA, 1979, p.313)

Ainda sobre o debate da questão racial em Gobineau, Meyer lembra que a miscigenação brasileira já se achava em estágio considerável quando o diplomata veio para o Brasil, uma vez que por aqui já desfilavam imigrantes provenientes de vários cantos do mundo. Para temperarmos ainda mais esse caldo, vejamos novamente o autor de $\grave{A}$ sombra da estante, em outro trecho de seu texto em que também fala da teoria racista de Gobineau. Diz, então, ele:

A "paisagem inédita" já então resumia uma experiência de três séculos e meio, com todos os complexos sociais de imigração e da mestiçagem em larga escala. E que riqueza de tons e entretons seria necessário empregar para reproduzir num mapa etnográfico a variedade de pigmentação, entecida na cruz surpreendente de tradições, usos, costumes, tudo em estado de fermentação imprevisível, em potencialidade bruta, como se algum demiurgo imaginoso tentasse, no cadinho de meio continente, precipitar a criação de um homem novo! (MEYER, 1947, p.16768) 
Aqui o escritor aponta para a complexidade da formação do povo brasileiro, o que, para um estudioso de etnias, poderia configurar um vasto objeto de estudo para a sustentação de sua tese, ou quem sabe até para a elaboração de outras hipóteses.

Traçadas as principais linhas da teoria de Gobineau, Brito Broca irá no momento seguinte prestar-nos mais conta de sua estada no Brasil. Assim, começa por dizer que:

\footnotetext{
Convicto da verdade da doutrina que formulara, Gobineau estabelecera a certeza de encontrar aqui uma sociedade inferior, onde nada poderia atraí-lo. (...) Não há o que lhe mereça atenção e muito menos um comentário tolerante na terra brasileira. O escritor chega a dar-nos uma impressão desfavorável de inteligência na maneira mesquinha de julgar as coisas, na verdadeira impertinência que a todo momento revela. (BROCA, 1979, p.313)
}

Brito Broca afirma que o diplomata recusou-se a admitir "a existência de qualquer intelectual brasileiro". Segundo ele, apenas "um homem nessa cafraria de negros, mulatos e caboclos, de mandriões e mentirosos, um homem apenas com quem se podia falar: o Imperador" (Ibidem, p.314); fato que o cronista contesta ao afirmar que "Se [Gobineau] declarava não ter com quem falar era, decerto, porque nunca procurara um José de Alencar, um Francisco Octaviano, um Macedo, um Nabuco de Araújo” (Ibidem). A mesma indignação vê o cronista quando, em carta a um amigo, Gobineau diz que "aqui nada encontra para fazer, pois não vê em jogo nenhum interesse francês, presente ou futuro". Possivelmente incomodado com isso, Broca diz:

A afirmação chega a parecer ironia se nos lembrarmos do que era a influência
francesa nessa época no Brasil e de como se vêm mantendo estreitamente unidos,
por objetivos e ideais comuns, até os dias presentes, os dois países. Mas no conceito
de Gobineau, decerto, semelhante aproximação só poderia prejudicar a França.
(BROCA, 1979, p.314)

Como se pode depreender, a estada de Gobineau no Brasil limitou-se, de sua parte, à dedicação de seus atributos como ministro da França e às visitas ao Imperador, com o qual falava "das antigas civilizações da Índia e do Egito, dos grandes problemas europeus, do grego, do hebraico e frequentemente de Matemática, assunto muito ao sabor do monarca e que desnorteava um pouco o diplomata francês" (Ibidem). Entretanto, mesmo nessas conversas com o Imperador, lembra Augusto Meyer, sempre "reitera os termos do seu pedido de licença: voltar, voltar é o seu refrão" (MEYER, 1947, p.171). 
Se, como afirma Broca, Gobineau não quis se aproximar de nossos intelectuais, tampouco o fez para apropriar-se - ainda que de maneira superficial - de qualquer forma de manifestação de nossa literatura.

Raeders nos relata que o Conde de Gobineau, entediado por encontrar-se no meio dos brasileiros, ocupou-se de dar cabo a alguns poemas que começara na Grécia. Também lia os clássicos e os romances franceses de autores contemporâneos, estes por encontrar com facilidade no Rio. Segundo Raeders,

Parece que da literatura brasileira propriamente dita só conheceu "um grande poema em português sobre a fundação do Rio. Bastante bonito, mas demasiado clássico, o que não o torna muito divertido". Provavelmente, trata-se de A Confederação dos Tamoios, poema épico de Domingos Gonçalves de Magalhães, visconde de Araguaia, publicado em 1856. (RAEDERS, 1996, p.65)

O diplomata francês não se interessou nem pela literatura nem pela história do Brasil, o que, de acordo com Raeders, "pode ser visto como uma nova prova do preconceito de Gobineau" (RAEDERS, 1996, p.65). Uma vez liquidados seus próprios trabalhos literários, passou a se dedicar à escultura.

No capítulo “O Brasil na obra de Gobineau”, é válido destacar, portanto, sua intenção de produzir uma Histoire des Deux Amériques, ideia logo abandonada em razão dos "desgostos" que havia sofrido entre os brasileiros. Escrever algo que se passasse aqui, também foi uma possibilidade que não lhe despertou interesse, como se verifica novamente com Raeders:

\footnotetext{
Recusou-se de uma vez por todas a escrever uma novela "brasileira". "Uma novela brasileira é impossível. Não há aqui o menor assunto a descobrir. A natureza é mais extraordinária do que bela; isso poderia servir, no entanto, de moldura. Mas o que colocar dentro? Os brasileiros não despertam nenhum interesse e não têm nem costumes nacionais nem nada de particular, a não ser uma excessiva depravação com a qual se pode fazer um livro muito severo e duro, mas não uma novela; e gosto demais do imperador para escrever só uma palavra contra este povo infame. Todos mulatos, a ralé do gênero humano, e costumes condizentes". (RAEDERS, 1996, p.77)
}

Com o intuito exclusivo de agradar o Imperador, Gobineau, segundo Raeders, teria escrito somente um trabalho completo sobre o Brasil: "L'émigration au Brésil". Trata-se de artigo publicado no Le Correspondant, nos números de julho e setembro de 1874, a respeito de dois livros: L'Empire du Brésil à l'Exposition Universelle de Vienne, de 1873, e Du Climat et des Maladies du Brésil, do doutor Lund. 
As considerações finais de Brito Broca, por sua vez, remontam à carta de Gobineau, já de volta à França, ao amigo Imperador, em que aquele afirma que não "descrê apenas do Brasil; descrê da América e da Segunda República Francesa” (BROCA, 1979, p.315).

Em relação ao objetivo do cronista, questionado no início dessa análise, parece ficar claro - como tem sido em outras crônicas em que essa intenção é mais explícita - que seu intuito foi investigar mais uma vez a presença francesa no Brasil. 
Anatole France e Georges Clemenceau (1909 - 1910)

Enfeixada em Escrita e vivência encontra-se a crônica "Política cultural de Rio Branco", cuja publicação data de 26 de novembro de 1950, no periódico A Manhã, Rio de Janeiro. O tema do artigo é a figura do barão do Rio Branco e as diversas personalidades da vida intelectual brasileira e estrangeira da época, reunidas dentro de seu projeto político de valorização cultural. Segundo Broca, depois de D. Pedro II, Rio Branco teria sido o primeiro estadista a estabelecer esse tipo de política, a qual "assinala uma grande fase de nossa vida intelectual". Continua ainda:

É o chamado1900, a nova idade de ouro, continuação indireta do período monárquico de 1870 -1889, após o interregno de perturbações da primeira década da República. Também a Europa vivia dias de esplendor e bonança - embora subterraneamente se conjugassem as forças que iriam deflagrar no verão de 1914 - a essa situação não deixava de influir na relativa tranquilidade da vida brasileira. (BROCA, 1993, p.177)

O início do século XX no Brasil foi tomado por grande euforia. No Rio de Janeiro, o prefeito Pereira Passos, com o intuito de afrancesar a capital da primeira República, institui seu plano urbanístico, o "bota-abaixo". A "febre de mundanismo", como sugere o cronista, reflete-se em vários setores da sociedade. Nas letras, a "atividade intelectual ia-se tornando algo de respeitável, desfazendo-se de suas tradições marginais”. Intelectuais como Domício da Gama, Graça Aranha, Rui Barbosa, Joaquim Nabuco, José Veríssimo, Machado de Assis, Capistrano de Abreu, João Ribeiro, Olavo Bilac, Aluísio Azevedo, Euclides da Cunha, Sílvio Romero e outros, formavam um grupo em que a aptidão de cada um estava a serviço da nação. Todos ligavam-se, de certa maneira, ao Itamarati.

Pode-se considerar que essa crônica possui um valor significativo dentro do conjunto da obra de Brito Broca. Não é sem motivo que o cronista fará uso dela em A vida literária no Brasil, sua obra de maior alcance. Possivelmente por causa de sua abrangência no trato da atuação do barão do Rio Branco e dos intelectuais que se aproximaram dele, assim como da presença daqueles que, por algum tipo de intermédio seu, vieram para o Brasil contribuir ainda mais com o processo de efervescência cultural que se verificou na primeira década daquele século. 
Em A vida literária, precisamente no Capítulo XVI dessa obra, é interessante notar que Brito Broca transfere, aprimora e amplia muitas das informações do artigo de 1950, dando-nos margem ao vulto que tomaria o projeto que aspirava dar conta de nossa vida literária, o qual teria início com o primeiro volume em que abarcaria o período colonial e o romantismo; o segundo, contendo o período naturalista; e o quarto em que pretendia retratar a fase modernista de nossa literatura. O terceiro volume é o que trata do 1900 que, em razão do farto material disponível, acabou sendo o primeiro a ser publicado. Por conta desse trabalho de aprimoramento de pesquisa é que iremos nos pautar ora na crônica de 1950 ora no seu formato ampliado de 1956, ano da publicação da primeira edição de A vida literária no Brasil, para empreendermos esta análise.

Dentro dos estudos das relações culturais Brasil-França, o destaque da crônica fica por conta do registro das visitas de Anatole France e de Georges Clemenceau, escritores estrangeiros que estiveram no Brasil em 1909 e 1910, respectivamente. Broca conta que:

A política cultural do barão processava-se, ativamente, tanto no plano interno, como no externo. Com a transformação da capital, a extinção da febre amarela, era preciso atrair figuras ilustres ao Brasil, para que fossem lá fora transmitir impressões favoráveis a nosso respeito. Essa época dos intelectuais no Itamarati foi aquela em que hospedamos alguns dos maiores vultos da cultura europeia, empenhando-se o ministro em fazê-los levar as melhores recordações do país. (BROCA, 2005, p.218)

Internamente, a ideia era reunir os nomes mais representativos da intelectualidade brasileira daquele período para que se concretizasse de fato um projeto de política cultural. Sendo assim, "O escritor tornara-se o que se poderia chamar homem sério. E nesse tom de seriedade agrupava Rio Branco os intelectuais no Itamarati, fazendo-os participar da grande obra que ali realizava, incorporando-os à ação política, compreendido este termo no mais elevado sentido" (BROCA, 1993, p.177).

No âmbito internacional, como já indicado por Broca, Rio Branco pretendia realizar uma espécie de propaganda do país, levando os estrangeiros que para cá viessem a voltarem seus olhos para um Brasil bem distante do ranço colonial de outrora. É nesse sentido que ganham força as conferências de estrangeiros no país.

Na crônica de Escrita e vivência, portanto, Brito Broca inicialmente faz um resumo da atuação desses intelectuais brasileiros e, na sequência, trata da visita dos dois escritores franceses. De Anatole France temos um único parágrafo: 
A visita de Anatole France, a 17 de maio de 1909, marcou outro belo momento de vibração intelectual no Brasil. Recebido na Academia de Letras, pôde o autor de Le Lys Rouge defrontar-se com Rui Barbosa, cuja consagração em Haia era recente, e o saudou num discurso que se tornou famoso. Apenas, Anatole não era um orador para grande público, e na sua conferência no Municipal foi um espirrar sem conta na plateia - segundo Gilberto Amado. Todo mundo estava constipado. (BROCA, 1993, p.180)

Quando comparada ao texto de A vida literária, observa-se, além da concisão, que muitas informações a respeito da estada de Anatole France acabam ganhando outro formato; os elementos básicos do texto permanecem, porém, cada um deles é melhor e mais desenvolvido, levando-nos a perceber um trabalho mais comprometido com os detalhes da visita. Alguns riscos, como levar o leitor a entender que France estivera no Brasil uma única vez, são eliminados. Na versão aprimorada para o livro é que percebemos que France, na verdade, desembarcara no Rio de Janeiro cumprindo parte da conexão que o levaria à Argentina e ao Uruguai. O Brasil só viria depois.

Broca nessa versão assinala, por exemplo, que Anatole France, a convite de alguns membros da Academia Brasileira de Letras, fez um passeio antes de prosseguir com a viagem. Rui Barbosa, como é apontado pelo cronista, foi de fato quem o recebeu com um discurso em uma sessão solene da Academia.

Se no artigo não se percebia exatamente qual era a fonte utilizada pelo cronista, em $A$ vida literária, isso não ocorrerá (pelo menos em relação France). Anatole France viera para sua visita à América do Sul acompanhado do secretário, Jean-Jacques Brousson, o qual, no livro Itinéraire de Paris à Buenos Aires, relata os passos do escritor. Tomando esta obra, Brito Broca consegue nos fazer enxergar a visão do estrangeiro sobre nós. Brousson relata o encontro dos acadêmicos, descrevendo-os "em termos verdadeiramente caricatos". O tom usado pelo acompanhante de France é mesmo irônico, como registra Broca:

Saúda-o em francês o presidente, Rui Barbosa, "esmagando-o de louros" - registra
Brousson -, "mas aos louros e às rosas mistura algumas urtigas. Louva a pureza do
estilo, verbera a impureza do fundo. Seu discurso cheira um pouco a homilia".
Anatole responde de improviso em poucas palavras, aludindo ao fato de no Brasil
não haver, como na Inglaterra, preconceitos de raça, considerando Rui Barbosa
campeão da "possibilidade da paz universal" e concluindo por saudar, na Academia,
uma cultura que fazia irradiar o espírito latino com altaneria e simplicidade.
(BROCA, 2005, p.232)

Vale lembrar que em $A$ vida literária, Brito Broca relata que antes mesmo de sua vinda para o Brasil, Anatole France havia presidido uma sessão em homenagem a Machado de Assis, na Sorbonne, em 3 de abril de 1909, "por iniciativa da Sociedade Parisiense e da 
Missão Brasileira de Propaganda" (BROCA, 2005, p.230). O discurso de Rui Barbosa é feito como forma de saudação e de agradecimento pela homenagem prestada a Machado, ao mesmo tempo em que se reveste de certo tom moralizante, como podemos perceber mais claramente com Regina Salgado Campos:

Em seu discurso de recepção a France na Academia Brasileira de Letras em 17 de maio, Rui Barbosa alude e agradece a participação do francês na sessão de homenagem a Machado de Assis. Em sua fala, em francês, Rui Barbosa mostra-se um leitor atento da obra de France, mas de maneira sutil introduz seu lado conservador e católico ao dizer: "Não nos resta senão perdoar todos os pecados de vossa alma pagã como a dos cristãos do Renascimento, quando se vêem jorrar de vossa paleta esses prodígios de inspiração”. (CAMPOS, 2004, p.87)

A atenção de Brito Broca não se volta para as questões tratadas acima - nem em relação ao ateísmo de France nem em relação ao espírito latino. Está mais interessado nos aspectos daquilo que sempre cuida na leitura que faz: a vida literária. Por esse motivo, por exemplo, é que relata em uma nota de rodapé a crítica de Lima Barreto a Rui Barbosa em virtude de sua palestra em homenagem a France. Aliás, a crítica deste escritor parece dirigirse a todos os membros da Academia, como lembra o cronista indicando o exagero de Lima Barreto em alguns pontos.

Uma consideração que pode ser feita em relação à crônica "Política cultural de Rio Branco", e ao que podemos chamar de sua ampliação em $A$ vida literária, reside no fato de que Brito Broca não indica o teor de nenhuma das conferências sul-americanas de Anatole France. Nem daquelas feitas no Brasil, quiçá na Argentina ou no Uruguai, países que primeiro ouviram suas palestras.

Segundo Campos, as conferências na Argentina tiveram dois temas. O primeiro tratava de Rabelais e o segundo da República argentina. Aquele, como indica a autora, não obteve muito êxito "em razão da própria escolha do tema que provocou reação do clero católico, desaconselhando a presença das mulheres, censurando o conferencista ateu e extremista que além tudo [vinha] falar de um escritor obsceno, grosseiro, ímpio" (CAMPOS, 2004, p.88). O segundo empolgou mais o público visto que o intelectual havia exposto suas impressões sobre a República vivida no país. Anatole France, de acordo com Campos,

Admite que a Inglaterra soube valorizar as qualidades argentinas, investindo no país, mas a França "à qual vos unem tantos laços de simpatias e tantas afinidades, associou-se mais lentamente, mais tardiamente, à vossa atividade". Havia preconceito contra as movimentações políticas, a desordem. Havia preconceito quanto aos costumes selvagens. Ignorava-se a cultura intelectual e moral argentina. 
Nos últimos dez anos, tal postura mudou: "Nossos agentes financeiros vos conhecem e vos estimam, nossos industriais mesmo têm os olhos voltados para vós e, há pouco tempo, só dependeu de vós ter um maior conhecimento de nossos metalúrgicos". (CAMPOS, 2004, p.89-90)

Regina Salgado Campos conclui que a boa repercussão dessa conferência, realizada em 29 de junho, se deve em razão do "papel político [do escritor] de louvar a falta de preconceito, o progresso e a promessa de paz futura na Argentina" que visitava.

Ainda com Campos, apreende-se da conferência "O Uruguai e seu Progresso", pronunciada em Montevidéu no dia 15 de julho, que France elogiou o país por sua tentativa de tornar-se uma nação laica, mais distante da influência religiosa. O escritor

Elogia o divórcio instituído no Uruguai e a abolição da pena de morte, ainda em
vigor na França. Faz a sugestão de que haja a separação da Igreja e do Estado, ao
constatar que a religião oficial do país é a católica. Há então toda uma argumentação
do anticlercial, que acaba por citar, como exemplo bem-sucedido, a Bélgica e o
Brasil. (CAMPOS, 2004, p.90-1)

Depois das visitas a esses países, Anatole France retornou ao Brasil para cumprir sua agenda de compromissos. Verifica-se tal registro, é preciso lembrar, somente em $A$ vida literária. Dessa forma, o cronista nos relata que France chegou no dia 22 de julho, "agora para permanecer uma semana e proferir duas conferências: 'Le positivisme et la paix du monde' e 'Le christianisme avant et après Jésus'” (BROCA, 2005, p.233). Segundo Broca,

O êxito das palestras não foi grande. Realizadas no Teatro Municipal à tarde, teriam atraído um pequeno público, mais curioso de ver em carne e osso o autor de Le Lys Rouge, do que interessado em acompanhar-lhe o pensamento sinuoso numa dissertação sem ênfase. Em crônica publicada n'O País (18-9-1910), Gilberto Amado relembraria, mais tarde, a quantidade verdadeiramente escandalosa de pessoas resfriadas que enchiam a sala do Municipal, quase chegando a cobrir a voz do orador com a multiplicação, sem conta, de espirros e fluxões. (BROCA, 2005, p.234)

A preocupação do cronista parece ser com aqueles que foram acompanhar a palestra de France. O conteúdo parece não lhe interessar muito - nem na crônica de 1950 nem depois, quando a revisitou para compor o livro. Interessa a Broca a atmosfera que envolvia o escritor francês e a sua elocução, pouco atrativa. Diante do comportamento da plateia, informa-nos Brito Broca que o Correio da Manhã, de 26-6-1909, teria divulgado uma nota em que se afirmava que em "Buenos Aires, por esnobismo, todo mundo quisera ouvir Anatole. Aqui, nem esse motivo prevalecera" (Ibidem).

A respeito da primeira conferência no Rio, sobre Auguste Comte, Campos nos instrui que Anatole France falou sobre "a presença do positivismo no Brasil a partir da bandeira 
republicana e seu lema 'Ordem e Progresso'”. O escritor teria elogiado "o positivismo como filosofia que, para ele, se mostrou a mais útil e a mais adaptada às aspirações dos povos modernos".

Na segunda conferência, esta em São Paulo, Anatole France falou no Teatro Sant'Ana sobre "Pierre Laffitte, un philosophe de bonne humeur". O escritor, afirma Broca, foi recebido com muito entusiasmo no dia 7 de agosto, "com a presença de todo o mundo oficial e de numeroso público (ao contrário do que se dera no Rio)” (BROCA, 2005, p.235) France também "visitou escolas, Museu do Ipiranga, instituições culturais, tendo sido recebido pelo presidente do estado, Albuquerque Lins" (Ibidem).

Comenta Campos que Anatole France apresentou Pierre Laffitte, o seguidor de Comte, como seu amigo pessoal. France, no início de sua exposição, elogiou “o ensino público paulista e a Faculdade de Direito", mostrando, porém suas limitações como orador. Apresentando-se como não positivista, o escritor pôde confrontar o positivismo defendido pelo brasileiro Teixeira Mendes, ao qual se ligava por simpatia, e o positivismo de Laffitte, ao qual se ligava por laços de amizade.

Broca, em contrapartida, prefere ater-se aos passos do escritor em São Paulo, deixando o conteúdo da conferência de lado. Dessa forma, informa-nos que France, após ter demonstrado interesse por conhecer uma fazenda de café, acabou visitando a propriedade do conde Prates. Segundo o cronista, Anatole Franco pôde "então verificar 'todas as operações que sofre o café até ser exposto à venda em grão' e testemunhar o conforto e o fausto de que podia cercar-se um fazendeiro em São Paulo". Lembra ainda que "seria esse o limite máximo a que chegaria a curiosidade pelo exótico num espírito tão visceralmente francês e parisiense". Brito Broca, para encerrar, considera que a visita de Anatole France no Brasil "marcou, certamente, um momento de efervescência cultural em que se falou muito em latinidade".

Com Clemenceau, tem-se o mesmo procedimento: a crônica de 1950 será o embrião do que Broca produzirá em A vida literária no Brasil. Alguns elementos do que podemos nomear como "primeira versão", serão retomados em 1956, outros serão modificados e haverá a inserção de novos, o que torna bastante claro o aprofundamento de sua pesquisa. A única 
diferença diz respeito ao conteúdo das conferências de Clemenceau que, no livro, serão mais exploradas pelo cronista.

Na crônica, o tema "Clemenceau" pode ser dividido em três partes: a primeira, em que Broca relata a chegada do escritor; a segunda, quando apresenta uma polêmica em torno de uma comissão que recepcionaria o visitante; e a terceira em que o cronista faz menção às três conferências de Clemenceau no Rio, "todas sobre a democracia".

É válido destacar que nessa crônica em que Brito Broca aborda os intelectuais que trabalharam dentro do projeto de política cultural de Rio Branco só é possível encontrar uma referência na qual ele poderia ter se baseado. No início de seu texto, o cronista lembra da “biografia já clássica do grande ministro", elaborada por Álvaro Lins, de 1945. Afora isso, nenhuma outra obra é citada por ele. O estudo de Lins aborda o período de permanência de Rio Branco na Europa (1876 - 1902), que "representa justamente uma época culminante da política internacional" (LINS, 1945, p.361). A menção ao livro talvez se deva ao fato dele ser uma das primeiras referências sobre o assunto. Percorrendo suas páginas, entretanto, verificase que o período em que Rio Branco exerceu suas atividades no comando do Ministério do Exterior não é registrado pelo biógrafo. Dessa forma, de onde Broca teria retirado as informações das visitas desses escritores estrangeiros?

Entretanto, sendo-lhe oferecida oportunidade de alçar voos mais altos em A vida literária, pode-se observar com mais frequência as indicações das obras de que faz uso. De modo geral, o novo suporte de seu texto, leva Brito Broca a cercar-se de mais detalhes - e com a ajuda das notas de rodapé, com o espaço mais maleável, maior tempo para pesquisa de determinada ocorrência, etc. -, conseguindo evitar certas lacunas deixadas nas páginas do jornal.

Dos elementos novos trazidos para esse novo formato de texto, podemos destacar que o cronista não mais o inicia com o momento da chegada de Georges Clemenceau no Brasil. Ele irá antes falar de uma nota publicada em um jornal em que se noticiava que alguns católicos planejavam uma recepção não muito amistosa ao escritor francês. Vejamos:

No dia 14 de setembro o Correio da Manhã publicava uma carta do acadêmico de direito Pio Benedito Otoni, dizendo ter lido nesse jornal a notícia de que alguns católicos programavam uma vaia à chegada de Clemenceau. Queria esclarecer a questão: o que se preparava era um movimento de solidariedade aos católicos espoliados de França. Constaria esse movimento de uma série de conferências em 
que oradores competentes e ilustrados analisariam a política de Clemenceau, o regime de exceção com que, em nome da liberdade, igualdade e fraternidade, oprimira os católicos do seu país. Partia a iniciativa da União Católica Brasileira, de que o missivista era secretário. (BROCA, 2005, p.236-7)

A presença de Clemenceau no Brasil teria irritado alguns católicos em razão de sua já conhecida postura anticlerical. Além disso, tratava-se de mais um estrangeiro cuja orientação política tomava como base a separação de vez de Estado e Igreja.

Na crônica de Escrita e vivência, Brito Broca nos informa que o “'Tigre' aqui chegou a 15 de setembro de 1910, vindo também de Buenos Aires, e Rio Branco preparou tudo para que ele fosse recebido avec la cordiale simplicité d'un ami” (BROCA, 1993, p.180). Informação que Broca complementa em $A$ vida literária, informando-nos que o escritor chegara "em companhia do dr. Cognard, (...) seu médico particular que o acompanhava em todas as excursões". Ainda nesse livro, o cronista acrescenta que embora cumprisse um contrato "em condições semelhantes a Anatole France, não deixou por isso indiferentes os poderes governamentais, que lhe prestaram expressivas homenagens" (BROCA, 2005, p.237).

Homenagens essas que não deixaram de provocar certa polêmica. Com base na crônica de 1950, verifica-se o total aproveitando do assunto em A vida literária, incluindo aí os mesmos termos empregados pelo cronista. A única mudança consiste na apresentação de outras desavenças resultantes da recepção que planejavam fazer a Clemenceau. A primeira parte, em que o deputado J. J. Seabra, líder da maioria na Câmara, "propôs se designasse uma comissão para comparecer ao desembarque do hóspede ilustre e saudá-lo em nome da casa", provocando a reação de Passos de Miranda, o qual se declarava "contrário à ideia" e se pôs "a analisar a personalidade de Clemenceau sob o tríplice aspecto: literário, científico e político”, é inteiramente aproveitada. O episódio se encerraria com o apoio do deputado católico Altino Arantes, alegando que Clemenceau tinha "muitos traços simpáticos para os católicos, como o de haver provocado a queda do gabinete Ferry, que fora contra o ensino religioso". A novidade trazida para o livro de 1956 refere-se aos senadores Francisco Glicério e Fernando Mendes. O primeiro "justificou um requerimento para que a casa se reunisse em sessão a fim de receber Clemenceau"; o segundo, "combateu a ideia, perguntando se já tinha havido precedentes". Mendes, ao receber uma resposta positiva, argumentou que "os outros traziam uma missão oficial, enquanto Clemenceau nos visitava apenas como turista". Um terceiro, o senador Lauro Sodré saiu em defesa do escritor francês, afirmando que "Clemenceau era o apóstolo da liberdade da consciência humana". A discussão prossegue: 
Interveio Glicério: ninguém poderia negar a Clemenceau o direito de representar a França; sabia que o colega do Maranhão [Fernando Mendes] combatia o requerimento exclusivamente pelo seu espírito religioso. Mas qual era o espírito religioso do Brasil? Vivíamos num regime em que a Igreja estava separada do Estado. E citava o caso de Joaquim Nabuco, recebido outrora no Parlamento português, sem estar investido de missão oficial. (BROCA, 2005, p.238)

Por fim, a discussão é encerrada. Fernando Mendes é acusado de reacionário por Antônio Azeredo; "e o requerimento, posto em votação, acaba sendo aprovado por todos, exceto pelo irredutível Fernando Mendes”. Clemenceau foi, então, saudado por Glicério e por Jorge Morais, orador oficial, que falou em francês.

Ainda nesse sentido, vale registrar a acolhida dada pelo presidente da República à ocasião e o barão do Rio Branco, como registra Regina Salgado Campos:

Embora não tenha vindo como convidado oficial, Clemenceau visita o Presidente da República Nilo Peçanha e é reconhecido pelo Barão do Rio Branco, que "é ministro das Relações Exteriores desde 1902 [e] exerceu as funções de cônsul geral em Paris". É muito bem recebido por ele e, segundo Clemenceau, "não esconde sua simpatia pela França, mas reserva sua admiração pela Alemanha. É dele a ideia, não concretizada, de uma missão militar alemã no Brasil". (CAMPOS, 2004, p.90-1)

A terceira parte da crônica, que também corresponde a um terceiro momento na versão revisitada em Vida literária, aborda as conferências de Georges Clemenceau no Brasil. Vejamos como o cronista nos relatou isso no artigo de 1950:

Clemenceau realizou três conferências no Rio, todas sobre a democracia, e improvisando sempre, como numa conversa com o público. Na primeira dela, observou, em dado momento, sentindo a sua perfeita comunicação com o auditório: "Nós, que falamos a mesma língua..." (BROCA, 1993, p.181)

Esse parágrafo é tudo que temos sobre as conferências do escritor francês, segundo a crônica de Escrita e vivência. Não nos possibilita, portanto, fazer qualquer comparação com a que Brito Broca desenvolve para sua obra. Não obstante, é possível localizar nesse fragmento alguns temas que serão posteriormente desenvolvidos pelo cronista. Por exemplo, o número de conferências realizadas por Clemenceau.

Em A vida literária, o cronista aponta seis, e não três, as conferências proferidas pelo escritor. Dentre essas seis, uma realizou-se em São Paulo, cidade à qual o cronista não se referira em 1950.

Brito Broca dessa vez traz o conteúdo das palestras de Clemenceau, diferente de como procedeu com France. Na primeira delas, que se realizou no dia 20 de setembro, o intelectual 
dissertou sobre "as origens da democracia". Broca chama a atenção para o "tom de conversa" com que falava o estrangeiro. Conta que o escritor

Em certa altura incitou os brasileiros a darem maior desenvolvimento e amplitude ao sentimento de latinidade que existe em nós, fazendo-o acompanhar de uma dose de empirismo, do senso prático e espírito comercial, a fim de obtermos o mais cedo possível os magníficos resultados da civilização norte-americana. (BROCA, 2005, p.238)

Clemenceau, relata Broca, conclui sua conferência afirmando que "os erros da democracia, apontados como prova de que ela nada vale, não são propriamente da democracia e sim dos homens aos quais cumpre aperfeiçoar" (Ibidem, p.239).

A segunda conferência ocorreu no dia 24 do mesmo mês. Clemenceau falou sobre a democracia e a Igreja. O escritor teria afirmado que "As relações do Estado com a Igreja nunca apresentaram aspectos tão delicados como nos dias atuais". O teor da conferência aponta para uma discussão a respeito do que na França havia sido essencial para a separação de Estado e Igreja: o ensino. "A França resolvera o problema instituindo a história leiga" (Ibidem).

Por causa das ideias de Clemenceau, conferências paralelas foram realizadas durante sua permanência no Brasil. Brito Broca registra alguma delas, como a do dia 23 (que deu início a uma série de outras tantas), em que os católicos sustentavam a "tese de que se tornava necessário um fundo religioso para que o governo democrático não degenerasse numa absoluta anarquia, sendo ele incompatível com o livre-pensamento"; e uma outra realizada no dia 26, na Associação dos Empregados do Comércio, em que se refutavam as ideias de Clemenceau.

A conferência de São Paulo realizou-se no dia 28 de setembro, também no Teatro Sant'Ana, como a de Anatole France. Antes de sua partida, o escritor faria ainda mais duas no Rio de Janeiro, dias 6 e 10 de outubro. O conteúdo de nenhuma das três palestras é abordado de maneira específica; são registradas apenas as linhas gerais do pronunciamento do escritor. Segundo Broca, Clemenceau

Falou do problema operário, das excelentes condições de equipamento das nossas Forças Armadas (aludindo à Força Pública de São Paulo, instruída por militares franceses), da questão religiosa e dos telegramas que recebera de Portugal. Terminou salientando a obra de Oswaldo Cruz e Vital Brasil, atribuindo-nos a primazia intelectual na América. De regresso à França, Clemenceau publicou o livro Notes de voyage dans l'Amérique du Sud, com referências amáveis ao Brasil. (BROCA, 2005, p.240) 
Como podemos ver, Brito Broca menciona o nome da obra que utilizou somente no final do relato sobre Clemenceau. Em 1950, no entanto, o cronista encerraria seu artigo desta forma: "De regresso à França, manifestou-se com muita simpatia sobre o Brasil, referindo-se particularmente à luminosa política exterior de Rio Branco" (BROCA, 1993, p.181).

Nesse último parágrafo da crônica de Escrita e vivência, embora Broca afirme que Clemenceau, uma vez na França, havia se manifestado de forma positiva sobre o país e sobre a atuação de Rio Branco à frente do Ministério das Relações Exteriores, não faz qualquer alusão de onde teria retirado essa informação. Somente em 1956, em A vida literária é que será possível verificar as inúmeras referências colhidas em jornais da época, como Gazeta de Notícias, Correio da Manhã, O Estado de S. Paulo etc., além dos nomes das obras que lhe serviram de consulta.

Regina Salgado Campos, nesse sentido, afirma que as impressões de Clemenceau sobre sua visita à América do Sul foram "publicadas inicialmente ainda em 1910, em capítulos no Illustration e depois em livro em 1911" (Ibidem, p.99). Afirma ainda que, "em seu livro, só os três últimos capítulos, dos quatorze que o compõem, referem-se especificamente ao Brasil".

A pesquisa sobre os visitantes franceses no Brasil durante a política cultural de Rio Branco se estende um pouco mais em A vida literária. No capítulo XVI da obra, depois de Clemenceau, Brito Broca ainda abordará a presença do Padre Gaffre, que, segundo ele, “excursionava pela América do Sul seguindo o mesmo itinerário do famoso político [Clemenceau], com o propósito de combater-lhe as ideias" (BROCA, 2005, p.240). O religioso também proferiria uma série de conferências, ainda em 1910.

Na sequência, o cronista fala de Paul Adam, o qual, afirma Broca, "iria dar grande extração, entre nós, à palavra 'latinidade"' (Ibidem, p.244). Veio para o Brasil em maio de 1911 "para uma prolongada permanência", em que pretendia estudar "o aspecto do problema das raças na América Latina".

Por fim, o poeta nicaraguano Rubén Darío, que esteve no Rio de Janeiro em junho de 1912, é outra personalidade destacada por Broca. O cronista fará ainda uma consideração final sobre seu levantamento das presenças ilustres no Brasil durante a política de Rio Branco, em que afirma que a frase faire l'Amérique havia se tornado um slogan da época. 
Paul Claudel e Darius Milhaud (1917)

Apesar do título da crônica ser "Claudel no Brasil", encontramos também a presença de outro francês, este músico, Darius Milhaud. O artigo se encontra em Escrita e vivência e foi publicado primeiramente em A Gazeta, a 20 de maio de 1959.

Broca inicia a crônica informando a seus leitores que Paul Claudel, embora fosse um poeta e teatrólogo de grande renome na França, aqui era quase um desconhecido. "Estreara há mais de vinte anos, em 1895, com os poemas 'Vers d'exil' e já havia publicado algumas de suas peças mais notáveis, como Tête d'Or, Partage de Midi e L'Annonce Faite à Marie". Nos jornais da época que noticiaram sua chegada ao Brasil, conta o cronista que referiam-se a ele "acidentalmente" como apenas um homem de letras. Broca comenta que Medeiros e Albuquerque, em Paris, enviando uma carta ${ }^{75}$ a Coelho Neto na qual descrevia Claudel como um "escritor curioso", afirma que ainda não havia descoberto a "genialidade" que todos na França aludiam. (BROCA, 1993, p.234)

Segundo o cronista, Claudel veio para o Brasil em fevereiro de 1917, como ministro da França em pleno curso da Primeira Guerra. No prefácio da correspondência do escritor com Darius Milhaud, Henri Hoppenot afirma que desde o conde de Gobineau, cuja missão remonta a 1870, a legação francesa no Brasil, salvo raras exceções, só havia recebido agentes em final de carreira. A indicação de Claudel, portanto, vinha romper com essa tradição. Sua missão era aproveitar-se do prestígio e da simpatia que a França gozava no país para obter algum tipo de auxílio em razão do estado de guerra em que se vivia na Europa. Darius Milhaud foi nomeado seu secretário pessoal por Philippe Berthelot; o músico também tinha a função de tentar desenvolver uma ação cultural no Brasil, ainda que embrionária.

Brito Broca afirma não ter conseguido apurar nenhuma relação de Paul Claudel com algum escritor brasileiro. A única exceção teria sido Rui Barbosa, então presidente da Academia, porém por "motivos alheios à literatura". Segundo o cronista, razões de ordem diplomática aproximaram Rui do "poeta-diplomata". Broca diz ignorar se Claudel "travou

\footnotetext{
${ }^{75}$ Em artigo publicado na Revista do livro, número dez, em junho de 1958, cujo título é "No arquivo de Coelho Neto", Brito Broca fez referência a esse fato. Apresentando a correspondência do escritor brasileiro com várias personalidades do mundo literário, o cronista relata a impressão de Medeiros e Albuquerque a respeito de Claudel. O tema "Claudel", portanto, levará o cronista a se revisitar no ano seguinte para compor essa crônica. O artigo encontra-se em Naturalistas, parnasianos e decadistas, 1991, p.264-311.
} 
relações igualmente com outros escritores de renome e tão francófilos como Rui, que muito fizeram pela entrada do Brasil na guerra ${ }^{76}$, como Medeiros e Albuquerque, Olavo Bilac, Coelho Neto, João do Rio" (BROCA, 1993, p.235).

O fato de ter Darius Milhaud como secretário concorreu para que Paul Claudel "se aproximasse mais dos meios artísticos e musicais", afirma Broca. Segundo ele, foi Milhaud "que o levou à casa do pai do pintor Carlos Oswald, de quem se tornou comensal e onde se fazia música". De posse das memórias do pintor, Broca nos informa que em sua casa "se reuniam, frequentemente, Milhaud, Luciano Gallet e Vila Lobos, todos interessados no aproveitamento musical de motivos do nosso folclore e fazendo ouvir ao piano suas produções inéditas no gênero".

É em razão da "importância" e do "interesse" que Paul Claudel sempre despertou em Carlos Oswald, que o músico dedica-se "mais amiúde" em sua presença durante o período que, juntamente com Milhaud, frequentou a casa de seus pais. Em suas memórias ${ }^{77}$, Oswald também relembra um pouco do clima de sua casa durante os encontros de diversas personalidades. Vejamos:

Foi naturalmente Darius Milhaud, músico de renome, que levou Claudel, do qual era secretário particular, à casa de meu pai, tornando-se assim o grande poeta assíduo frequentador daquelas reuniões. (...) Tanto ele como seu secretário, e este ainda mais, eram fervorosos entusiastas do "folk-lore" brasileiro que naquele tempo começava a interessar os ambientes musicais do Rio. Se não me engano Milhaud foi dos primeiros (pelo menos entre os estrangeiros) a aproveitar-se das músicas populares da nossa gente e que com Luciano Gallet e Villa-Lobos constituiu, a meu ver, o primeiro grupo de pioneiros vulgarizadores do nosso Folk-lore. As "soirées" eram interessantíssimas. Cada um dos compositores fazia ouvir suas produções inéditas e me lembro dos primeiros ensaios de Milhaud quando, sentado ao piano, nos esboçava com uma "verve" surpreendente e uma técnica pianística exótica, trechos de seu "ballet" tirado da conhecida canção "O boi no telhado" e que ele intitulava "Le boeuf sur le toît". Composição que teve posteriormente um sucesso formidável em Paris. (OSWALD, 1957, 63-4)

Em sua crônica, Brito Broca registra ainda que "Claudel parecera a Carlos Oswald um espírito jovial, alegre, sociável, de uma sem-cerimônia às vezes até desconcertante". Com o próprio Oswald, podemos juntar ainda essa declaração:

\footnotetext{
${ }^{76}$ Sobre o tema, vale conferir a crônica "Quando estávamos em Guerra”, enfeixada em Teatro das letras, 1993, p.88-92. Nela, Brito Broca relata como foi a repercussão da Primeira Guerra entre os escritores brasileiros, sobretudo José Veríssimo, o qual teve alguns de seus artigos transcritos no Le Temps e na Revue Universitaire, segundo o cronista.

${ }^{77}$ Em Como me tornei pintor, 1957, no Capítulo IV “Período da Grande Guerra”, p. 63-6.
} 
Quando conheci Claudel, a primeira impressão que tive foi a de ser apresentado ao dono do armazém da esquina!... tão diferente mostrava ser seu aspecto físico com a espiritualidade de sua obra. Mas quando ele me olhou bem nos olhos, minha opinião mudou radicalmente. (OSWALD, 1957, p.64)

Acompanhando a autobiografia de Oswald, é possível perceber que Broca segue o mesmo percurso indicado pelo pintor em suas memórias. Há, por exemplo, o registro de duas situações que mostram o caráter tão "sem-cerimônia" do escritor. Vejamos:

Na ocasião de embarcar para a França (tinha ido promovido de ministro a embaixador, na Rússia), fez questão de lembrar à mamãe certos biscoitinhos que ela magistralmente confeccionava, e ao embarcar saiu com a lata de biscoitos na mão. Noutra ocasião, em que me visitou, veio acompanhado do secretário particular Milhaud, do secretário de Legação e de outra funcionária; estavam comigo meus pais e outras pessoas. A casa de papai era ali perto, na Rua S. Francisco Xavier, e, à noitinha, quando todos saíram, mamãe, simplesmente por cerimônia, convidou-o para jantar e, logo entusiasmado, ele aceitou: "allons, alons tout de suíte". Mamãe caiu das nuvens, quase teve um chilique, pois nada tinha de preparado para tanta gente, e que gente! (OSWALD, 1957, p.65)

As recordações do pintor não se restringem apenas a Claudel. A casa do pai de Carlos Oswald era frequentada por pessoas como "Rubinstein, Brailowsky, Respighi, Zecchi, Marinuzzi, Casals, Guiomar Novaes, Villa-Lobos, Lorenzo Fernandes, Mignone, e tantos e tantos outros músicos e vultos como Agache e [o próprio] Paulo Claudel" (Ibidem, p.63). Dentro da mesma parte dedicada ao poeta, Oswald relata, por exemplo, a sua relação com Milhaud. Conta ele que certa vez pintou um retrato cubista do compositor que, segundo suas descrições, "era (...) um sujeito cheio de corpo, pálido rosado, vivo; tudo nele era arredondado". O resultado agradou muito Milhaud que, retornando a Paris, "mandou reproduzir seu retrato cubista e o fez imprimir no alto das páginas de seu bloco de escrever". O músico enviou um exemplar a Oswald com uma nota, dizendo que o público vanguardista parisiense muito havia se admirado em constatar que no "longínquo, selvagem Brasil havia cubistas..."

As memórias de Carlos Oswald, segundo Brito Broca, representam o "único depoimento que possuímos sobre as relações de Claudel no ambiente artístico e intelectual do Rio”. Claudel teria viajado pelo Brasil, visitando São Paulo, Minas, Paraná e Rio Grande do Sul, onde, conclui o cronista, "foi portador de uma jarra de porcelana, (...) oferta, dos positivistas franceses aos positivistas gaúchos" (BROCA, 1993, p.235-6). No entanto, parecenos que o maior registro que se tem de sua estada no Brasil encontra-se mesmo dentro sua obra. 
Brito Broca afirma que Claudel impressionou-se tanto com a paisagem do Rio que chegou a declarar que era a única das grandes cidades do mundo entre as que conhecia que não havia expulsado a natureza. $\mathrm{O}$ cronista relata-nos ainda que

No prefácio do livro da esposa de Nijinsky sobre este, Claudel relembra a ocasião em que vira o grande bailarino no Rio e evoca as mil sonoridades da noite carioca, nessa metrópole onde a floresta procurava penetrar por todos os cantos. (BROCA, 1993, p.236)

A apresentação de Nijinsky impressionara muito o poeta e seu amigo Milhaud, como podemos verificar também com Henri Hoppenot, no prefácio da correspondência entre o músico e Claudel:

Les spectacles de la célèbre troupe l'enthousiasmèrent et lui ouvrirent des perspectives nouvelles d'expressions lyrique pour lesquelles il se passionna. Il ne douta pas d'être appelé, avec l'aide de Milhaud, à révolutionner le Ballet. L'Homme et son désir, La Femme et son ombre émergèrent de ce bouillonnement de projets, souvent géniaux et irréalisables. (HOPPENOT, 1961, p.12)

Nesse sentido, o registro de Darius Milhaud sobre o episódio ocorrido naquele ano em que a companhia russa se apresentava no Brasil também é valioso uma vez que o compositor se encontrava junto com Claudel. Em Études, o músico relata o seguinte:

En 1917, Claudel est nommé ministre de France au Brésil et m'emmène comme secrétaire. Nous passons deux années de ce pays merveilleux en contact avec la grande forêt tropicale. C'est à cette époque que nous pensons à notre balet L'Homme et son Désir. Les Ballets Russes jouent une représentation à Rio: cettes furent les dernières soirées où dansa Nijinski, et c'est en pensant à lui que Claudel écrivit son Poème plastique. Peu d'oeuvres nous ont tellement amusés à bâtir. Dans cette grande solitude, à un mois des courriers d'Europe, nous avions le temps de laisser mûrir et d'édifier tout doucement une oeuvre qui était devenue pour nous comme un jouet. Pendant que j'écrivais ma partition, Claudel imaginait les moindres details de sa chorégraphie chez notre amie Mrs. Audrey Parr, qui sur les indications de Claudel, faisait notre décor. Ele avait une charmante habitation à Pétropolis où nous venions, pour nous reposer des chaleurs de l'été tropical, passer le week-end. Là, elle avait fait construire un tout petit théatre qui se posait sur une table et avait fait les différents étages sur lesquels se déroule la tragique action de ce balet. En haut les Heures, au-dessous la Lune et les Nuages, au milieu le Drame, l'Homme et la Forêt, drame de la nuit, du rêve, du souvenir et d l'amour, et enfin, en bas, le reflet de la Lune et le reflet des Nuages. Nous découpions des personnages de quinze centimètres avec des papiers colorés et c'est ainsi que nous avons réglé tout notre ballet. Il fut représenté en 1921 à Paris par les Ballets Suédois et derniérement à Vienne et à Dresde par l'École de Hellerau. (MILHAUD, 1927, p.32-3)

Audrey Parr (ou Margotine) era a esposa de Raymond Parr, diplomata da legação britânica no Brasil. O casal, como afirma Henri Hoppenot, residia numa casa em Petrópolis. Em seu prefácio, Hoppenot descreve-nos um outro lado dessa passagem, em que podemos notar, acima de tudo, um pouco da personalidade do poeta. Conta ele que 
Margotine dessinait avec goût et se montrait compréhensive et docile. Son mérite était grand car Claudel n'était pas un maître facile. Infatigable, ignorant la fatigue des autres, insensible à l'accablante chaleur brésilienne, il maintenait Margotine pendant des heures penchée sur ses feuilles de dessin, appliquée à rendre de son mieux, dans leurs versions successives et précipitées, les scènes et les attitudes qu'il lui décrivait ou lui mimait. (HOPPENOT, 1961, p.19)

É interessante notar que, em Broca, encontramos uma referência à criação dessa peça em que o cronista informa que "o bailado L'Homme et son Désir, (...) inspirado em ritmos cariocas" teria sido representado em Paris em 1918, e não em 1921 como indicado por Darius Milhaud. O cronista ainda assinala a seus leitores que Jean-Claude Berton teria afirmado que o meio brasileiro influenciou a obra de Claudel por conta, principalmente, da sua proximidade com Darius Milhaud "que aqui se impregnou de motivos do nosso folclore". Os relatos de Carlos Oswald, Hoppenot e do próprio Milhaud nos afirmam isso.

A missão brasileira de Claudel termina juntamente com o armistício da Primeira Guerra, em novembro de 1918. Já de volta a seu país, Brito Broca declara que Claudel "teria confessado na radiofusão francesa que, embora localizando a ação em outro ambiente, foi com a atmosfera do Brasil, com as recordações do Brasil, que veio a criar o meio no qual decorre a peça Le Soulier de Satin" (BROCA, 1993, p.236). 
Abel Bonnard e Tristão de Athayde (1927)

“Um amigo de Proust no Brasil, em 1927”. Este é o título dado por Brito Broca a uma crônica publicada por três vezes em diferentes períodos e lugares. A primeira aparição data de 11 de março de 1958, em A Gazeta; a segunda de 6 de agosto de 1960, no Correio da Manhã; e a última, desta vez em livro, deu-se em 1993 inserida na obra Teatro das letras, organizada por Orna Messer Levin, de acordo com o projeto Obras reunidas.

O livro Océan et Brésil é o estopim da crônica. A obra de Abel Bonnard ${ }^{78}$, adquirida por Broca "por preço de liquidação num alfarrabista", serve de pretexto para que ele relembre a estada desse admirador de Charles Maurras ${ }^{79}$ em terras brasileiras, no ano de 1927, "quando os jornais do Rio de Janeiro e São Paulo estampavam o retrato do escritor em visita ao nosso país” (BROCA, 1993, p.153). O cronista nos afirma que após a libertação de Paris, soubera apenas que o escritor havia se refugiado na Espanha ${ }^{80}$, e que depois disso não havia ouvido nenhuma outra notícia a seu respeito.

Abel Bonnard (1883 - 1968) foi poeta, romancista, ensaísta e político. Chegou à baía de Guanabara a bordo do iate La Resolue, no qual também viajava o rei do açúcar da França. Tal informação nos é prestada por Broca que irá relembrar a visita do escritor francês após ler o artigo de Tristão de Athayde:

No artigo “Ariel entre os guindastes”, publicado em 1929, quando apareceu Océan et Brésil e incluído no $4^{\circ}$ volume dos Estudos (Edição do Centro Dom Vital), Tristão de Athayde recorda essa visita, dizendo da emoção que experimentou ao conhecer e ao conversar longamente com o escritor, cujos artigos de há muito o vinham encantando nos jornais franceses. (BROCA, 1993, p.153)

\footnotetext{
${ }^{78}$ Le Figaro, Le Journal, Comoedia e Paris-Midi foram alguns dos jornais em que Bonnard trabalhou. Entrou para a política no ano de 1925 por sua colaboração no Le Nouveau Siècle, e depois no Courrier Royal, juntamente com Henry Bordeaux e George Bernanos. Como romancista, Abel Bonnard teve diversas obras publicadas na França, chegando a ser eleito membro da Academia Francesa em 1932.

${ }^{79}$ Fundador do nacionalismo integral na França, Charles Maurras (1868-1952) teve suas ideias amplamente divulgadas nos vários jornais em que escreveu, sobretudo no L'Action française. Refutava os ideais românticos e defendia uma concepção clássica do pensamento francês. Foi fortemente influenciado pelas ideias de Anatole France, Maurice Barrès e Auguste Comte. Assumidamente anti-dreyfusard, sua filosofia política pregava o nacionalismo integral por meio da monarquia tradicional, hereditária, antiparlamentarista e descentralizada. Foi contrário ao Tratado de Versalhes e em 1945, após a guerra, foi condenado à reclusão.

${ }^{80}$ Acusado de ter exercido intensa atividade colaboracionista e antisemita durante o período, Abel Bonnard, condenado à morte, acabou refugiando-se na Espanha de onde retornou em 1960.
} 
Neste trecho, é preciso lembrar, o que chama nossa atenção é a citação direta da fonte utilizada pelo cronista. Não é raro encontrarmos referências a muitas delas em seus textos, bem como não é raro notar-lhes as ausências; no entanto, aqui Broca nos fornece de modo mais explícito a origem de uma de suas consultas - autor, ano de publicação, editora etc. -, ou seja, tudo aquilo a que sempre somos chamados a não esquecer ou omitir em trabalhos de caráter acadêmico. Teria sido tal gesto fruto de um autopoliciamento do cronista, uma vez que havia acabado de produzir sua obra de maior alcance, relatando nossa vida literária ${ }^{81}$, e que por esse motivo passou a ser mais cuidadoso com relação às fontes utilizadas? De qualquer forma, o texto de Tristão de Athayde parece ser a ponte que conduz Brito Broca ao livro de Abel Bonnard. É nele que o cronista encontrará os indícios de que o escritor francês era amigo de algumas personalidades do mundo literário da época. Ainda é no referido artigo que Broca buscará inspiração para dar título à sua crônica. Vejamos:

Nessa tarde de agosto de 1927, portanto, quando eu me dirigia para a vulgaridade eccletica e baixamente mundana do Alvear, afim de ser apresentado a esse amigo de Proust, de Fargue, de Valéry, de Thibaudet, - confesso que levava commigo uma curiosidade ardente. (ATHAYDE, 1931, p.19)

O título escolhido pelo cronista parece ter muito mais a intenção de atrair leitores do que esclarecer qualquer aspecto da relação que Bonnard pudesse ter tido com o autor de $\grave{A}$ la recherche du temps perdu. Isso em razão de que tanto no decorrer da crônica quanto na leitura do artigo de Tristão de Athayde verifica-se que nenhuma outra menção é feita a essa amizade com Marcel Proust capaz de justificar o aparecimento do nome do escritor ali.

A crônica está dividida basicamente em duas partes: uma em que Brito Broca destaca a admiração de Tristão de Athayde pelo francês e outra quando o cronista trata de alguns aspectos da obra de Abel Bonnard.

$\mathrm{Na}$ primeira sequência, Broca relata para o leitor um encontro entre Tristão de Athayde e Abel Bonnard. A conversa que se iniciara na Confeitaria Alvear, posteriormente é deslocada para o cais Mauá, em meio a seus guindastes; e Brito Broca insere um pouco do sentimento do anfitrião frente ao ilustre visitante:

${ }^{81}$ A primeira edição de A vida literária no Brasil - 1900 surgiu em 1957, em edição do Serviço de Documentação do Ministério da Educação e Cultura. A segunda, revista e ampliada pelo próprio cronista, surgiria em 1960. 
Considerando-o um espírito altamente requintado, uma flor da civilização, sentia o contraste de sua presença nesta terra jovem, ainda com resquícios de barbárie. Mas Abel Bonnard, que tinha sido amigo de Proust e se habituara a conviver com Valéry, Faguet e Thibaudet, personificação típica do refinamento parisiense, sempre experimentara a mais viva curiosidade pelos povos exóticos e distantes. Dois livros anteriormente publicados, En Chine e Au Marroc, bem diziam das longínquas fronteiras a que ele já tinha levado as suas peregrinações. (BROCA, 1993, p.153)

Além de confirmar o que se disse há pouco em relação ao título da crônica, aqui também temos uma boa ideia do que representava a figura de Bonnard - e o peso de sua civilização - para Tristão de Athayde. Broca, entretanto, poupa seus leitores de alguns excessos do crítico brasileiro que chega a dizer em seu artigo que Bonnard "passava entre a grosseria ambiente como uma briza irônica e indifferente, tocando em tudo sem se alterar em nada" (ATHAYDE, 1931, p.21). O artigo de Tristão de Athayde, vale lembrar, também mostra as impressões do estrangeiro sobre nosso país a partir de sua leitura de Océan et Brésil.

Na segunda parte da crônica, Brito Broca volta-se para o livro de Abel Bonnard, o qual traz o roteiro do francês em sua visita ao Brasil. Assim, conta o cronista que

Chegando ao Rio, depois de escalar na Ilha da Madeira, em Tenerife e São Vicente, não pôde deixar de extasiar-se ante as montanhas que circundam a baía de Guanabara, traduzindo para o francês os nomes de cada um dos picos e dizendo que aqui esses próprios nomes mostram que a coisa é diferente da Europa ("qu'il s'agit de tout autres jeux") e o barroco triunfa. (BROCA, 1993, p.154)

É dessa forma, explicitando o itinerário de Abel Bonnard e as suas impressões sobre a exótica terra, que Brito Broca prosseguirá sua crônica. Uma vez comparados esses dois textos, de Broca e de Bonnard, chama bastante nossa atenção o decalque que faz o cronista das informações acima prestadas, salvo os nomes das montanhas, vertidos para o francês. Vejamos:

Ici, le seul nom des montagnes principales suffit à annoncer qu'il s'agit de tout autres jeux et que le baroque triomphe. Voici le Bossu, le Géant Couché, le Bec de Perroquet, le Grand Hunier, les Orgues, le Doigt de Dieu et le célèbre Pain de Sucre, que les premiers Français qui vinrent dans les pays appelaient le Pot de Beurre. (BONNARD, 1929, p.55)

Aqui temos, pois, os nomes de algumas das montanhas da cidade do Rio de Janeiro numa versão em francês, como advertia Brito Broca. No entanto, é interessante observar o delineamento do processo de incorporação de uma fonte ao corpo do texto. Com este 
fragmento, conseguimos compreender um pouco do método utilizado pelo cronista quando escrevia seus artigos. Mais uma vez somos levados a considerar que sua atuação diante de certos textos se diferencia da que utilizamos atualmente, e que mesmo não revelando diretamente sua fonte, as informações prestadas por ele são sempre com base em sua pesquisa, séria e compromissada com seu público leitor.

A leitura de Brito Broca prossegue dando-nos conta das impressões de Abel Bonnard sobre o Brasil. Comovido com a beleza da cidade, o francês parece "lamentar apenas que o homem não se mostre mais sensível aos incitamentos da natureza circundante" (BROCA, 1993, p.154). Ao que parece, Bonnard sugeria que, em vez de se "recordar-se de Paris e Bruxelas, deveria construir em tal sítio palácios 'de l'emphase la plus justifiée' entre o contínuo tributo dos jardins e a perpétua homenagem das vagas” (Ibidem, p.154-5). Tão interessante quanto essa consideração do escritor, é o lamento de Broca a esse respeito, logo adiante:

\begin{abstract}
Nessa época o céu ainda não possuía arranha-céus. Que diria Abel Bonnard da "ênfase" desses palácios com que hoje estamos estragando completamente a natureza? Decerto, quando desejou para o Rio uma arquitetura diferente da de Paris e Bruxelas (não assinalando a portuguesa, então predominante), a "Ariel" de Tristão de Athayde não teria pensado na brutalidade dos arranha-céus ${ }^{82}$. (BROCA, 1993, p.155)
\end{abstract}

Outra situação que parece irritar o cronista diz respeito à visita de Bonnard ao Instituto Butantã, em São Paulo. Vejamos primeiro as palavras do francês:

\begin{abstract}
Voici d'autres bêtes, ce sont les serpents. Nous sommes venus les voir dans le grand établissement où l'on compose les serums qui guérissent de leurs morsures, si l'on y recourt sans retard. C'est à Butentan, près de Sain-Paul. Sous un ciel chargé de nuages, nous nous promenons dans le jardin; les serpents venimeux y sont tenus à part, sur un terrain qu'entourent un étroit fosse plein d'eau et une cloture basse. (BONNARD, 1929, p.69)
\end{abstract}

De acordo com Brito Broca, em 1927, data da visita de Bonnard, já não se encontravam mais cobras nas ruas do Rio de Janeiro, “como em 1903 'acontecera' a Antoine", quando este foi surpreendido por um "estranho brasileiro" que lhe perguntou se queria comprar peles de serpentes. Posto isto, o cronista afirma:

\footnotetext{
${ }^{82}$ É notória a admiração de Brito Broca pela cidade do Rio de Janeiro. O capítulo "São Paulo é feio... O Rio, sim, é uma beleza!", em Memórias; a reportagem "Onde anda o meu Rio de Janeiro”, de Augusto Souza Meyer; e "Roteiro literário do Rio de Janeiro", ambos inseridos em $O$ repórter impenitente, são provas disso.
} 
(...) o fato de apresentarmos o Butantã ao estrangeiro, como atração turística, sempre concorreu para que na Europa se ligasse o nome do Brasil à existência de cobras. Abel Bonnard não deixou de fazer essa visita clássica em São Paulo, descrevendo-a em quatro páginas do livro. (BROCA, 1993, p.155)

A irritação do cronista, portanto, recai sobre os próprios brasileiros que, dentre os vários estereótipos que já gravitavam ao redor do nome do nosso país, auxiliaram na construção de mais um.

Em seu mapeamento da obra de Abel Bonnard, Brito Broca continua sua crônica, destacando agora o capítulo "L'ame du monde", no qual, segundo ele, Bonnard "tece algumas considerações de caráter psicológico sobre as relações e as diferenças específicas entre a França, o Brasil e as Américas.” (Ibidem, p.155) Certamente por ter de se adaptar ao espaço destinado à sua crônica, muitas questões tratadas pelo francês foram postas de lados. Dessa forma, nosso esforço aqui também será o de apresentar algumas das impressões desse visitante sobre nosso país.

De saída, verifica-se nesse capítulo uma tentativa de classificar o habitante nativo em relação ao homem civilizado e europeu, herdeiro de uma tradição da qual o brasileiro não pode se valer; uma tentativa de definir e compreender o que é ser latino. Vejamos:

Ce luxe un peu mince, cette abondance de jeunes gens et de jeunes filles, cette
banale prodigalité de beaux yeux, ce n'est pas du tout la foule de Paris, mais c'est
presque celle de Rome. On a le sentiment de voir s'étendre jusqu'ici l'immense
tache humaine qu'on appelle latine, sans que ce mot ait d'autre valeur que de
designer commodément le mélange de races très confus qui s'est operé sur les rives
de la Méditerranée orientale. (...) L'importance de la France au Brésil n'est pas due à
des affinités faciles et inférieures, elle a des raisons plus hautes: on la regarde come
la nation de l'esprit. Elle exerce ici, dans l'ordre intellectuel, la même prépondérance
que les Etats-Unis dans le monde des affaires. On est touché de voir avec quel
empressement les Brésiliens accueillent les Français qui leur paraissent capables de
répondre à l'avidité de leurs intelligences. Ils nous montrent les trésors de leur sol et
nous demandent ceux de notre culture. Cela rappelle la franchise et la naïveté des
anciens échanges: ils nous offrent des papillons et nous demandent des idées.
(BONNARD, 1929, p.73-4)

Bonnard faz uso do termo "latino" para designar uma mistura de raças como a ocorrida no Mediterrâneo oriental, o que nos levar a pensar que seu emprego associa-se muito mais ao processo de miscigenação dos povos daquela região do que uma tentativa de conferir uma identidade aos habitantes do país. Ao tocar ainda na questão da França como referência para nós - que lhes oferecemos borboletas em troca de suas ideias - faz uma clara alusão ao 
sistema de escambo muito utilizado pelos colonizadores para conquistar a confiança dos indígenas.

Um pouco mais a frente, Bonnard afirma que a América é o ponto de encontro de raças, com exceção ao projeto de nação estabelecido por alguns países, sobretudo os Estados Unidos, que conseguiram preservar suas origens. Diz ele:

\begin{abstract}
L'Amérique, au Nord comme au Sud, est moins un monde determiné qu'un théâtre immense: c'est le lieu de la rencontre de races. Les Occidentaux, Anglo-Saxons ou Méditerranéens, y ont trouvé les Indiens, y ont amené les Noirs et on voulu en écarter les Chinois et les Japonais. On sait avec quelle opiniâtreté les Américains du Nord ont, jusqu'à ce jour, preservé la propreté de leur sang et nous ne manquerons jamais, quant à nous, de dire qu'en agissant ainsi, ils ont rempli leur premier devoir et rendu à l'humanité un service insigne. Dans le Sud, au contraire, on a laissé tout arriver: l'étranger qui voit, dans les rues de Rio ou de Bahia, quelle variété de colorations présente le teint des passants ne peut pas douter que le vrai drame de ce pays ne soit dans le mélange des sangs, dans cette lutte sournoise où les différentes génies de l'humanité s'enlacent comme des serpents. Sans doute ce drame est trop intime et trop sourd, il touche à trop d'amours-propres pour être avoué dans des paroles. Mais il passione l'esprit du voyageur: on se demande quelle peut être au juste la nature de cet homme qu'on vient de frôler, en qui le sang noir verse le goût de l'emphase et le sang indien le goût du secret. (BONNARD, 1929, p.77)
\end{abstract}

Contrapondo o modelo norte-americano ao brasileiro, em que o primeiro representa uma organização que tinha como propósito garantir a união de seu povo e o segundo uma terra onde quase não havia regras, tampouco um projeto para se constituir uma nação, Bonnard conclui que o drama dos brasileiros se instala numa questão de amor-próprio, muito íntima e bastante silenciosa.

Os romances de Graça Aranha e Afrânio Peixoto, traduzidos para o francês e sem os quais Bonnard não teria tomado conhecimento de nossa literatura visto que não compreendia nossa língua, são obras que também levam o visitante a fazer algumas conjecturas sobre nossa sociedade. Após a leitura "de ces courts poèmes que composent, au Brésil, les habitants de la solitude"(BONNARD, 1929, p.84), comenta ele que:

Ces oeuvres sans art ne sont pas sans charme: on y trouve une mélancolie dont on n'est pas étonné, car elle a au moins deux causes: l'une, extérieure, est dans la disparité de l'homme avec un nature qui l'accable, l'autre, intime, resulte des différents sangs dont le chanteur subit les poussées contraires. (BONNARD, 1929, p.84-5)

Este discurso parece se afinar ainda mais quando logo adiante, no mesmo capítulo, Bonnard volta ao tema suscitado pela obra dos dois brasileiros, no momento em que compara 
a natureza do país à indeterminação de seu povo. Acompanhemos, mais uma vez, as palavras de Bonnard:

La nature du Brésil est parfois la maitresse de l'homme, mais elle n'est jamais son épouse. Elle l'accable de ses caresses ou de ses colères. (...) Les sociétés humaines qui flottent dans ces espaces trop vastes ne soutiennent pas davantage celui qui veut accéder à une vie supérieure. Non pas qu'il manque de prédécesseurs: il n'appartient à un monde indeterminé. (...) Nous ne nous rendons pas assez compte du bonheur que c'est de sortir d'une longue et sûre lignée, de pouvoir sans cesse nous appuyer aux oeuvres de notre race, aux palais et aux églises qu'elle a bâties, aux musées et aux bibliothèques qu'elle emplit de son témoignage. (...) Ici, au contraire, celui qui, par son effort isolé, se porte jusqu'à la hauteur ou règnent les grands esprits est d'autant plus offert à toutes les influences qu'il n'est soutenu par aucune tradition, et il est alors presque inevitable que, dans les sentiments qu'il éprouve, l'excès se mêle au hasard. Le grand homme qu'il evoque dans ses veilles se présente à lui avec un ascendant irrésistible et, fascine par ce puissant sorcier, il n'est même pas sûr de s'être donné le maître qui convient vraiment à sa nature. (BONNARD, 1929, p.86-9)

Dominado por um discurso bastante conservador, Bonnard destaca a importância para um país, e seus escritores, de se ter uma linhagem, uma referência a ser seguida, marcando a oposição da situação do escritor brasileiro, cujas referências, segundo o francês, não existiam.

Essas considerações todas são feitas quando Bonnard se achava no Rio de Janeiro. O escritor teria ainda visitado Ouro Preto, a qual não o impressionou em razão dos traços europeus da cidade. Broca, surpreendido com a reação do francês, comenta:

Não teria encontrado ali um guia para contar-lhe a história dos inconfidentes e o idílio de Marília e Gonzaga, enfim, o que constitui o lustre histórico e romanesco daquelas casas velhas, onde não descobriu outra coisa senão o tédio? (BROCA, 1993, p.156)

Sua intenção era ir ao Amazonas, mas - como depreende Broca da leitura de Tristão de Athayde -, sendo desencorajado, Bonnard acaba partindo para o Iguaçu, no Paraná. A viagem rende muitos capítulos e constitui, segundo Broca, a melhor parte de seu livro.

Há outro capítulo, este dedicado à Bahia, "já visitada na viagem de regresso" em que “temos de novo a visão do 'oceano' e as meditações de um francês ultracivilizado que retorna ao Velho Mundo.” (Ibidem, p.156) O destaque que para nós parece ser o maior diz respeito à nova consideração que Bonnard faz referindo-se à nossa história.

J'avais grande envie de voir Bahia. Les Brésiliens en parlent volontiers, pour prouver qu'ils ont un passé. Dans ce pays où la sensation, à la fois éclatante et mince, ressemble à un tableau dont les couleurs vives, étalées crûment sur la toile, ne s'appuieraient jamais à une préparation qui les nourrisse et qui les soutienne, on devient singulièrement avide d'éprouver quelque chose d'un peu plus profond. Je comptais sur la vieille cité coloniale pour satisfaire ce désir. (BONNARD, 1929, p.199-200) 
Broca parte para as considerações finais de sua crônica, comentando que Bonnard procurou observar nosso "jovem país” e tirar algumas conclusões. Segundo ele, há na obra referências a pessoas que Bonnard teria conhecido, dentre as quais um "moço cheio de inteligência e bonito, admirador de Charles Marras" (BROCA, 1993, p.156), o que leva Broca a desconfiar que este fosse Tristão de Athayde. 


\section{Considerações finais}

O estudo sobre as relações culturais Brasil-França nas crônicas de Brito Broca, tendo como corpus os artigos que tratam da presença de escritores e intelectuais franceses aqui e a presença de escritores e intelectuais brasileiros na França, procurou inicialmente promover uma discussão a respeito do conceito de crônica. Queríamos traçar seu histórico e verificar a possível contribuição de Brito Broca para o gênero. Entretanto, ao longo da leitura dos artigos do cronista fomos constatando que em vários deles Broca mostrava sua posição em relação ao gênero no mesmo momento em que tentava conceituá-lo para o leitor.

Dessa forma, no artigo de 1958, em que Broca trata da atualidade do gênero crônica na França, fomos levados a verificar que a definição aceita por ele ia ao encontro daquela defendida pelos franceses, qual seja, o relato de acontecimentos juntamente com o “comentário sobre os mesmos, comentário leve, ressaltando determinados aspectos, estabelecendo paralelos, esclarecendo, e tirando conclusões" (BROCA, 1969, p.116). Feito isso, pudemos constatar que a contribuição de Brito Broca para a crônica reside justamente na sua maneira de abordá-la. Assim, valendo-se de fatos da vida literária, o cronista conseguiu imprimir sua marca no próprio modo de contar a literatura.

Ainda considerando a crônica, num segundo momento tentamos verificar qual a posição de especialistas de formação universitária a respeito de um trabalho realizado em jornais e revistas especializadas. Traçamos, então, um breve relato da atuação profissional de Broca para confirmamos sua dedicação à divulgação da literatura na imprensa, e em seguida confrontamos as opiniões de alguns críticos de formação acadêmica, cujos critérios no tratamento dos estudos literários tomam como base as teorias desenvolvidas dentro das próprias universidades, para compreender o posicionamento deles diante de um projeto crítico todo elaborado por meio de crônicas literárias cuja base era o autodidatismo de seu criador. Assim, pudemos constatar que um dos problemas enfrentados por aqueles que desenvolvem o mesmo tipo de trabalho que Broca está no próprio meio de divulgação, como reflete Candido:

Isto acontece porque [a crônica] não tem pretensões a durar, uma vez que é filha do jornal e da era da máquina, onde tudo acaba tão depressa. Ela não foi feita originalmente para o livro, mas para essa publicação efêmera que se compra num dia 
e no dia seguinte é usada para embrulhar um par de sapatos ou forrar o chão da cozinha. (CANDIDO, 1992, p.14)

Entretanto, uma das discussões apontadas mostrou-nos que quando a crônica perde seu caráter transitório e passa das páginas do jornal para o livro, tem seu poder de durabilidade ampliado, já que dentro do contexto do livro podemos nos debruçar sobre ela com mais afinco, descobrindo outras características e possibilidades interpretativas que outrora eram impossíveis em razão da sua transitoriedade. A mudança de suporte provocaria, portanto, um novo direcionamento. Basta considerarmos que o público do jornal é mais apressado e mais envolvido com as outras matérias apresentadas na folha do que o público do livro, mais seletivo e reflexivo, apto a uma leitura mais crítica. Sem falar na unidade temática, proposta por Silviano Santiago, que possibilita uma leitura em que se pode estabelecer uma correlação entre os artigos.

Nesse contexto, o estudo das relações Brasil-França, considerando os franceses que para cá vieram e os brasileiros que para lá foram, em razão da insistência do próprio cronista em investigar esses intercâmbios, tornou-se por excelência o objeto deste trabalho.

Após estabelecer uma apresentação cronológica desses artigos, levando em conta o período em que essas visitas ocorreram, nossa abordagem procurou verificar a maneira como Brito Broca tratou do assunto em suas crônicas. Quando nos era possível seguir a referência indicada por ele, operávamos uma investigação para compreender de que forma e até onde o cronista tomava sua fonte como base. E era aí que percebíamos que mesmo acompanhando essa referência, outras informações nos escapavam, pois parecia que o cronista sempre guardava alguma carta escondida em sua manga, de modo que algumas perguntas continuaram sem respostas. Em contrapartida, quando não tínhamos suas referências para o assunto de uma crônica, recorríamos a outras, estabelecendo paralelos com seu texto.

Em relação à estrutura dessas crônicas, conseguimos verificar que Broca sempre usava de alguns artifícios, como o resumo da vida de um escritor ou intelectual que estava sendo abordado por ele. Desse modo, garantiria a seu leitor maior apreensão dos fatos a serem narrados. Outras vezes, fazia um pequeno balanço sobre determinado assunto antes de abordálo de modo mais objetivo, como na crônica "Quando um escritor brasileiro entrevistou Zola", em que faz uma série de questionamentos sobre o motivo que teria levado alguns escritores brasileiros a não relatarem seus possíveis contatos com escritores ou intelectuais europeus. 
A análise das crônicas também nos levou a compreender um pouco do processo criador de Broca, sobretudo quando pudemos comparar o artigo sobre Rio Branco ao capítulo de A vida literária no Brasil, em que ele revisita seu próprio texto e nele insere várias outras informações em função das pesquisas de aprimoramento de seu conteúdo. Assim, alguns escritores e intelectuais que não apareciam antes no artigo, passaram a compor mais tarde o quadro em que o cronista procurou retratar a política cultural do Barão.

A respeito dos intercâmbios entre culturas, podemos concluir que o interesse do Brasil pela cultura francesa vai ser privilegiado em ambos os grupos de crônicas: tanto nos que relatam a estada de brasileiros na França quanto naqueles que mostram a presença de franceses aqui. A influência francesa se faz notar tanto pelo desejo que alguns brasileiros nutriam em conviver com os grandes escritores e intelectuais franceses quanto pela vontade de participar de todas as ideias disseminadas por eles no Brasil.

Dessa forma, o levantamento e a análise dessas crônicas também nos pareceram válidos ao menos em dois sentidos. O primeiro deles diz respeito à constatação de que o interesse em divulgar a literatura francesa é algo recorrente em Brito Broca, fato que o levou a nos deixar quadros interessantes das relações Brasil-França com base nos aspectos da vida literária. $\mathrm{O}$ segundo refere-se a outras possibilidades de pesquisa que se abrem após o estudo de suas crônicas, em que foi possível identificar obras e nomes poucos usuais dentro desse tipo de literatura.

Para finalizar, vale destacar o importante papel de vulgarizador que Brito Broca exerceu. A sua concepção sobre a função desse tipo de obra esclarece muitas de nossas observações sobre seu trabalho. Diz ele: "Quando abrimos uma obra de vulgarização, não é para conhecermos as ideias do autor, mas as ideias dos outros, que ele se encarregou de veicular. Ser esta uma função subalterna, como reputa muita gente, me parece discutível" (BROCA, 1991, p.324). De fato, acreditamos, não se tratar de subalternidade. Ao desempenhar essa função, Brito Broca realizava ao mesmo tempo um grande levantamento de temas relevantes ao estudo da literatura, seja ela brasileira ou estrangeira. Assim, mais do que vulgarizar obras pouco conhecidas, o que Broca nos legou foram instigantes pontos de referências. 


\section{Referências bibliográficas}

AGASSIZZ, E. C.; AGASSIZ, L. Viagem ao Brasil - 1865-1866. Tradução João Etienne Fiho. Belo Horizonte: Editora Itatiaia; São Paulo: Editora da Universidade de São Paulo, 1975.

ANDRADE, C. D. Ameno companheiro. Remate de Males, Campinas, (11): 115-6, 1991.

ANDRADE, P. J. C. Memória, ficção e aforismos: o cronista Brito Broca em formação. São Paulo, 2008. Dissertação (Mestrado) - Faculdade de Filosofia, Letras e Ciências Humanas, Universidade de São Paulo. Disponível em: <www.teses.usp.br>. Acesso em: 15 abr. 2010.

AQUINO, J.T. Discurso preliminar: apologético e crítico. In: CAMÕES, L. Os Lusíadas. Paris: Casa J-P Aillaud, Guillard, 1865. Disponível em: 〈www.books.google.com.br〉. Acesso em: 14 jan. 2010.

ARAGO, J. Souvenirs d'un aveugle: Voyage autour du monde. Paris: Chez H. Lebrun éditeur, [s.d.].

ARRIGUCCI JR., Davi. Fragmentos sobre a crônica. In: Enigma e comentário: ensaios sobre literatura e experiência. 2. ed. São Paulo: Companhia das letras, 2001, p. 51-66.

AUERBACH, Erich. Mimesis: a representação da realidade na literatura ocidental. 4. ed. São Paulo: Perspectiva, 2001.

BARBOSA, F. de A. "Um D. Quixote das Letras" - Prefácio. In: BROCA, J. B. Memórias. Rio de Janeiro: José Olympio, 1968.

BARBOSA, N. L. As "Letras Francesas” do Suplemento Literário OESP: dois momentos duas leituras. São Paulo, 2001. Dissertação (Mestrado) - Faculdade de Filosofia, Letras e Ciências Humanas, Universidade de São Paulo.

BARBOSA, R. O processo do capitão Dreyfus (cartas da Inglaterra). São Paulo: Giordano, 1994. 
BERRETTINI, C. Introdução. In: HUGO, V. Do grotesco e do sublime - Prefácio de Cromwell. Tradução e notas Célia Berrettini. São Paulo: Perspectiva, 2002, p.7-12.

BERRIEL, C. E. O. (Org.) Apresentação. In: BROCA, J. B. Horas de leitura. $1^{\mathrm{a}}$ e $2^{\mathrm{a}}$ séries. Campinas, SP: Editora da UNICAMP, 1992.

BETTI, M. S. Na trilha do mestre: Décio de Almeida Prado como formador. In: FARIA, J. R.; ARÊAS, V.; AGUIAR, F. (org.) Décio de Almeida Prado: um homem de teatro. São Paulo: Editora da Universidade de São Paulo, 1997, p.93-110.

BIARD, F. Dois anos no Brasil. Tradução Mario Sette. Rio de Janeiro: Companhia Editora Nacional, 1945.

BOLLE, A. B. M. A obra crítica de Álvaro Lins e sua função histórica. Petrópolis, RJ: Vozes, 1979.

BOSI, A. História concisa da literatura brasileira. 42. ed. São Paulo: Cultrix, 2004.

O Positivismo no Brasil: uma ideologia de longa duração. In: PERRONE-MOISÉS, L. (Org.) Do positivismo à Desconstrução: Ideias Francesas na América. São Paulo: Editora da Universidade de São Paulo, 2004, p.17-47.

BROCA, J. B. Memórias. Organizado, anotado e com introdução de Francisco de Assis Barbosa. Rio de Janeiro: José Olympio, 1968. Letras francesas. São Paulo: Conselho Estadual de Cultura, IMESP, 1969. Românticos, pré-românticos, ultra-românticos: vida literária e romantismo. São Paulo: Polis; Brasília: INL, 1979.

Ensaios da mão canhestra: Cervantes, Goethe, Dostoievski, Alencar, Coelho Netto, Pompéia. São Paulo: Polis; Brasília: INL, 1981.

. Machado de Assis e a política: mais outros estudos. São Paulo: Polis; Brasília: INL, Fundação Pró-Memória, 1983.

Papéis de Alceste. Campinas, SP: Editora da UNICAMP, 1991. 
- Naturalistas, parnasianos e decadistas: vida literária do realismo ao prémodernismo. Campinas, SP: Editora da UNICAMP, 1991.

. Horas de leitura: $1^{\mathrm{a}}$. e 2 ${ }^{\mathrm{a}}$. séries. Campinas, SP: Editora da UNICAMP, 1992.

. Teatro das letras. Campinas, SP: Editora da UNICAMP, 1993.

. Escrita e vivência. Campinas, SP: Editora da UNICAMP, 1993.

. O repórter impenitente. Campinas, SP: Editora da UNICAMP, 1994.

. Americanos. Campinas, SP: Editora da UNICAMP, 1998.

. A vida literária no Brasil - 1900. 5. ed. Rio de Janeiro: José Olympio: Academia

Brasileira de Letras, 2005.

BRUNEL, P., PICHOIS, C., ROUSSEAU, A. M. Que é literatura comparada? São Paulo: Perspectiva, 1995.

CAMPOS, R. S. Ceticismo e Responsabilidade: Gide e Montaigne na obra crítica de Sérgio Milliet. São Paulo: Annablume, 1996.

A Latinidade na América do Sul: Anatole France e Paul Adam. In: PERRONEMOISÉS, L. (Org.) Do positivismo à Desconstrução: Ideias Francesas na América. São Paulo: Editora da Universidade de São Paulo, 2004, p.79-125.

CANDIDO, A. et al. A crônica: o gênero, sua fixação e suas transformações no Brasil. Campinas, SP: Editora da UNICAMP; Rio de Janeiro: Fundação Casa de Rui Barbosa, 1992, p.13-22.

Prefácio. In: BROCA, J. B. Ensaios da mão canhestra: Cervantes, Goethe, Dostoievski, Alencar, Coelho Netto, Pompeia. São Paulo: Polis; Brasília: UNL, 1981, p.7-10. . Literatura e cultura de 1900 a 1945. In: . Literatura e sociedade. 8. ed. São

Paulo: T.A. Queiroz Editor, 2000, p.109-38.

CLEMENCEAU, G. Notes de voyage dans l'Amérique du Sud - Argentine - Uruguay Brésil. Préface Jean-Louis Marfaing. Paris : UNESCO ; Utz, 1991. 
COSTA, J. A. F. (Org.) Estudo histórico-biográfico. In: SALDANHA, J. N. Poesias. Pernambuco: J.W. de Medeiros, 1875.

COUTINHO, A. Ensaio e crônica. In. (dir.), COUTINHO, E. F. (codir.). A literatura no Brasil. 4. ed. São Paulo: Global, 1997, v.6, p.117-43.

DINES, A. Dreyfus, ou a guerra das manchetes. In: BARBOSA, R. O processo do capitão Dreyfus (cartas da Inglaterra). São Paulo: Editora Giordano, 1994, p.11-33.

DUARTE, C. L. Nísia Floresta: vida e obra. In: FLORESTA, N. Itinerário de uma viagem à Alemanha. Tradução Francisco das Chagas Pereira. Santa Cruz do Sul: Edunisc; Florianópolis: Ed. Mulheres, 1998, p.19-33.

EAGLETON, T. A função da crítica. Tradução Jefferson Luiz Camargo). São Paulo: Martins Fontes, 1991.

EULALIO, A. Prefácio. In: BROCA, J. B. Românticos, pré-românticos, ultra-românticos: vida literária e romantismo. São Paulo: Polis; Brasília: INL, 1979, p.9-14.

FAUSTO, B. História do Brasil. 13. ed. São Paulo: Editora da Universidade de São Paulo, 2008.

FRANÇA JR., J. J. Folhetins. 4. ed. Rio de Janeiro: Jacintho Ribeiro dos Santos (editor), 1926.

Política e costumes: Folhetins esquecidos (1867-1868). Rio de Janeiro: Civilização Brasileira, 1957.

FREYRE, G. Um engenheiro francês no Brasil. (Prefácio do Prof. Paul Arbousse-Bastide). Rio de Janeiro: José Olympio, 1960. $1^{\circ}$ tomo.

GAMA, Visconde Nogueira da. Minhas memórias. Magalhães \& Comp. Editores: Rio de Janeiro, 1893.

GUERREIRO, J. A. T. O affaire Dreyfus e as cartas de Inglaterra de Rui Barbosa. In: BARBOSA, R. O processo do capitão Dreyfus (cartas da Inglaterra). São Paulo: Editora Giordano, 1994, p. 35-68. 
GUIMARÃES, A. Vida e morte de Natividade Saldanha (1796-1832). Lisboa: Luz-Braz, 1932.

HOPPENOT, H. Préface. In :Cahiers Paul Claudel 3: Correspondance Paul Claudel - Darius Milhaud (1912-1953). Paris, Gallimard, 1961, p.7-24.

HUGO, V. Do grotesco e do sublime - Prefácio de Cromwell. Tradução e notas Célia Berrettini. São Paulo: Perspectiva, 2002.

LIMA, I. S. Bibliografia dos patronos: Artur de Oliveira e Basílio da Gama. Rio de Janeiro: Francisco Alves, 1997. Coleção Afrânio Peixoto, da Academia Brasileira de Letras.

LINS, A. Rio Branco: O Barão do Rio Branco, 1845 - 1912. Rio de Janeiro: José Olympio, 1945.

LOPES, R. (Org.) Cartas a Monte Alverne (Porto Alegre - Gonçalves de Magalhães). São Paulo: Conselho Estadual de Cultura, 1964.

LOPES, A.; MOTA, G. C. História do Brasil: uma interpretação. São Paulo: Editora Senac São Paulo, 2008.

MAGAlHÃES, D. J. G. Suspiros poéticos e saudades. 5. ed. Brasília, Editora da Universidade de Brasília; INL - Instituto Nacional do Livro, 1986.

MARETTI, M. L. L. As letras francesas de Brito Broca. (No prelo)

MARTINS FILHO, E. L. Manual de redação e estilo de O Estado de S. Paulo. 3. ed. São Paulo: O Estado de S. Paulo, 1997.

MARTINS, A. L. Revistas em revista: imprensa e práticas culturais em tempos de República, São Paulo (1890-1922). São Paulo: Editora da Universidade de São Paulo: Fapesp: Imprensa Oficial do Estado, 2001.

MARTINS, A. L.; LUCA, T. R. (Organizadoras) História da imprensa no Brasil. São Paulo: Contexto, 2008.

MEYER, A. À sombra da estante. Rio de Janeiro: José Olympio, 1947. 
MONTEIRO, T. O Presidente Campos Sales na Europa. Belo Horizonte: Itatiaia; São Paulo: Editora da Universidade de São Paulo, 1983.

NITRINI, S. Literatura comparada: História, teoria e crítica. São Paulo: Editora da Universidade de São Paulo, 1997.

PEDRA BRANCA, Domingo Borges de Barros, Visconde da. Poesias oferecidas as senhoras brazileiras, por um bahiano. Paris: Chez Aillaud, 1825.

PERRONE-MOISÉS, L. (org.) Do positivismo à Desconstrução: Ideias Francesas na América. São Paulo: Editora da Universidade de São Paulo, 2004.

PRADO, D. A. João Caetano: o ator, o empresário, o repertório. São Paulo: Perspectiva, Editora da Universidade de São Paulo, 1972.

. História concisa do teatro brasileiro: 1570 - 1908. São Paulo: Editora da Universidade de São Paulo, 1999.

RAEDERS, G. Dom Pedro II e o Conde de Gobineau. São Paulo: Companhia Editora Nacional, 1938.

O Conde de Gobineau no Brasil. Rio de Janeiro: Paz e Terra, 1996.

RIO BRANCO, José Maria da Silva Paranhos, Visconde do. Cartas ao amigo ausente. [Rio de Janeiro]: Ministério das Relações Exteriores, Instituto Rio Branco, 1953.

SALDANHA, J. N. Poesias. Pernambuco: J.W. de Medeiros, 1875.

SILVA, L. João Caetano e sua época: subsídios para a história do teatro brasileiro. Boletim do Instituto Histórico e Geográfico Brasileiro. Rio de Janeiro: Imprensa Nacional, 1936.

RANGEL, A. Textos e pretextos. França: Arrault e Cia., 1926.

RIVAS, P. Encontro entre literaturas: França, Portugal, Brasil. São Paulo: Editora Hucitec, 1995.

. Diálogos interculturais. São Paulo: Editora Hucitec, 2005.

SÁ, J. de A crônica. 6. ed. São Paulo: Ática, 2002. 
SAMOYAULT, Tiphaine. L’intertextualité. Mémoire de la littérature. Paris: Nathan, 2001.

SANTIAGO, S. Força Subterrânea - Prefácio. In: BROCA, J. B. Machado de Assis e a Política: mais outros estudos. São Paulo: Polis; Brasília: INL, Fundação Pró-Memória, 1983, p. $9-15$.

"Lenha na fogueira (leituras em francês de Brito Broca)". Remate de Males, Campinas, (11): 61-66, 1991.

SENA, H. Prefácio. In: BROCA, J. B. Papéis de Alceste. Campinas, SP: Editora da UNICAMP, 1991, p. 9-15.

. Uma voz contra a injustiça: Rui Barbosa e o caso Dreyfus. 2. ed. Rio de Janeiro:

Edições Casa de Rui Barbosa, 2004.

SIMÕES JR., A. S. "A contribuição de Bilac para a crônica brasileira”. In: O eixo e a roda: revista de literatura brasileira, 2003/2004. Belo Horizonte. Faculdade de Letras da UFMG, p.235-246.

SOUTO, L. F. V. Artur de Oliveira. Ensaio biográfico. Rio de Janeiro: Civilização Brasileira, 1935.

SPERBER, S. F. Alceste, o contraditório. In: BROCA, J. B. Papéis de Alceste. Campinas, SP: Editora da UNICAMP, 1991, p.17-21.

SQUEFF, L. O Brasil nas letras de um pintor. Manuel de Araújo Porto Alegre (1806-1879). Campinas, SP: Editora UNICAMP, 2004.

VIDAL, B. Precursoras Brasileiras. Rio de Janeiro: A Noite, [194-?]. 